The author(s) shown below used Federal funds provided by the U.S. Department of Justice and prepared the following final report:

Document Title: Gender Differences in Drug Market Activities: A Comparative Assessment of Men and Women's Participation in the Drug Market

Author(s): $\quad$ Nancy Rodriguez, Ph.D.; Marie L. Griffin, Ph.D.

Document No.: $\quad 211974$

Date Received: November 2005

Award Number: $\quad$ 2004-IJ-CX-0014

This report has not been published by the U.S. Department of Justice. To provide better customer service, NCJRS has made this Federallyfunded grant final report available electronically in addition to traditional paper copies.

Opinions or points of view expressed are those of the author(s) and do not necessarily reflect the official position or policies of the U.S. Department of Justice. 
Gender Differences in Drug Market Activities: A Comparative Assessment of

\author{
Men and Women's Participation in the Drug Market
}

Nancy Rodriguez, Ph.D.

Marie L. Griffin, Ph.D.

Criminal Justice and Criminology

Arizona State University

September 2005

This project was supported by Grant No. 2004-IJ-CX-0014 awarded by the National Institute of Justice, Office of Justice Programs, U.S. Department of Justice. Points of view in this document are those of the authors and do not necessarily represent the official position or policies of the U.S. Department of Justice. 


\begin{tabular}{|l|c|}
\hline \multicolumn{1}{|c|}{ TABLE OF CONTENTS } & \\
\hline \multicolumn{1}{|c|}{} & Page \\
\hline EXECUTIVE SUMMARY & 1 \\
\hline INTRODUCTION & 3 \\
\hline LITERATURE REVIEW & 4 \\
\hline Women's Involvement in the Drug Economy & 4 \\
\hline Social Networks and Gender & 6 \\
\hline Social Networks and Drug Markets & 8 \\
\hline Social Networks and Crime Involved Women & 9 \\
\hline THE CURRENT STUDY & 11 \\
\hline METHODOLOGY & 13 \\
\hline Data & 13 \\
\hline Sample & 15 \\
\hline Measures & 15 \\
\hline Analytical Strategy & 17 \\
\hline FINDINGS & 18 \\
\hline Description of Female Arrestees & 18 \\
\hline Description of Male Arrestees & 20 \\
\hline Gender Differences in Drug Acquisition Behavior & 23 \\
\hline Gender Specific Models - Females' Drug Acquisition Behavior and & \\
Community Characteristics & 24 \\
\hline Gender Specific Models - Males' Drug Acquisition Behavior and & \\
Community Characteristics & 25 \\
\hline DISCUSSION & 27 \\
\hline REFERENCES & 35 \\
\hline TABLES & 41 \\
\hline APPENDIX A: Description of Models & 59 \\
\hline APPENDIX B: Combined Sample Models & 60 \\
\hline APPENDIX C: Female Models & 91 \\
\hline APPENDIX D: Male Models & 122 \\
\hline
\end{tabular}




\section{EXECUTIVE SUMMARY}

\section{Background}

Prior studies have examined women's involvement with drugs, focusing both on women's use of drugs, and their role in drug distribution networks (Denton \& O’Malley, 1999; Fagan, 1994; Maxwell \& Maxwell, 2000; Morgan \& Joe, 1996; Sommers \& Baskin, 1996). Research has also examined the way in which gender structures women's opportunities to engage in the street-level drug economy (Adler, 1985; Baskin, Sommers, \& Fagan, 1993; Fagan, 1994; Griffin \& Armstrong, 2003; Inciardi, Lockwood, \& Pottieger, 1993; Maher \& Curtis, 1992; Maher \& Daly, 1996).

This study adds to this existing body of research by examining drug market activity and the manner in which such behavior differs by gender. Specifically, the concept of social networks is used to inform these analyses and to examine specific drug market acquisition behaviors. Consistent with prior work that has noted the importance of the community in which the drug market is located (Curtis \& Wendel, 2000), this study also examines the extent to which community characteristics influence drug market behavior.

\section{Research Questions:}

1. Women are less likely than men to have obtained a drug through cash transaction during the past 30 days;

2. Women are more likely than men to have obtained a drug through noncash transaction during the past 30 days;

3. Women are more likely than men to go to a house or apartment to obtain a drug;

4. Women are less likely than men to approach a person in public to obtain a drug;

5. Women are less likely than men to be with the person already when obtaining a drug;

6. Women are less likely than men to purchase a drug directly;

7. Women are more likely than men to use a regular source;

8. Women are more likely than men to purchase a drug indoors;

9. Women are more likely than men to remain in their own neighborhood to purchase a drug;

10. Women are less likely than men to acquire a drug on credit;

11. Women are less likely than men to acquire a drug by being fronted to sell;

12. Women are less likely than men to acquire a drug through trade;

13. Women are more likely than men to acquire a drug in exchange for sex;

14. Women are more likely than men to acquire a drug as a gift;

15. Community-level variables will influence, directly and indirectly (through gender), drug market acquisition behaviors.

\section{Methodology}

Data for this study comes from the Arrestee Drug Abuse Monitoring (ADAM) program from 39 ADAM sites during 2000 - 2003. The sample includes 129,189 adult male arrestees and 24,575 
female adult arrestees. In order to incorporate community-level measures into the analyses, arrestees' residential zip codes were used to link zip code-level data from the 2000 Census.

\section{Summary of Major Findings}

- Males were more likely than females to acquire three of the five drugs (i.e., marijuana, cocaine, and methamphetamines) through cash transactions.

- Females were more likely than males to acquire four of the five drugs (i.e., marijuana, crack, cocaine, and methamphetamines) through noncash transactions.

- Females were more likely than males to go to a house or an apartment to obtain crack through cash transactions.

- Females were less likely than males to approach a person in public to obtain drugs through cash and noncash transactions.

- Females were less likely than males to be with the person when obtaining a drug through noncash transactions. No gender effect was found in cash transactions.

- Gender did not influence the likelihood of an arrestee purchasing drugs directly.

- Females were more likely than males to purchase drugs from a regular source, purchase drugs indoors, and remain within their neighborhood when making the purchase.

- Males were more likely than females to acquire drugs on credit, by fronting to sell, and by trading drugs and/or merchandise.

- Females were more likely than males to acquire drugs through sex.

- Females were more likely than males to acquire drugs by receiving them as a gift.

- Gender effects on acquisition behaviors are not constant across drug types.

- The effects of drug market indicators across communities varied more for males than females. Also, the effects of community characteristics were more likely to be significant in the male than female models.

\section{Discussion/Conclusion}

The findings presented here indicate that male and female arrestees employ different strategies when obtaining drugs. For example, women appear to rely on a more limited array of social contacts than men when acquiring drugs. These different strategies reflect the gendered culture of street level drug markets and the influence of personal networks on women's involvement in criminal activity. Resources (i.e., obtaining drugs through cash versus noncash means) also appear to play a significant role in drug acquisition behavior. Therefore, studies of gender and drug market behavior must be sensitive to the nature of the drug transaction. Lastly, gender, drug type, and community characteristics are far more interrelated than independent in drug market activity. Research in this area must not assume that the effects of gender or drug type are constant across various drug market behaviors but rather are differently "embedded" within social structures. 
Gender Differences in Drug Market Activities: A Comparative Assessment of Men and Women’s Participation in the Drug Market

\section{Introduction}

Since the early 1980’s, there has been a substantial increase in the number of women who have been sentenced to jail and prison for non-violent, drug offenses. Some scholars have argued that the 'war on drugs' has become a war on women, contributing significantly to the escalating population of women in prison (Chesney-Lind, 1997; Wilson, 1993). In an effort to understand the complex relationship between illicit drug use, crime, and gender, studies have examined women's involvement with drugs, focusing both on women's use of drugs, and their role in drug distribution networks (Denton \& O’Malley, 1999; Fagan, 1994; Maxwell \& Maxwell, 2000; Morgan \& Joe, 1996; Sommers \& Baskin, 1996). Such research has provided insight, at times conflicting, into the changing nature of illicit drug markets and women's roles within this illegitimate economy. This study adds to the existing body of research by examining drug market activity and the manner in which such behavior differs by gender. Specifically, this study utilizes the concept of social networks to inform our analyses and examine specific drug market acquisition behaviors. Social network analyses suggest that opportunities and constraints are influenced by an individual's location within the social structure (Molm, 2001). Using data collected from 39 ADAM sites, this study examines measures of drug market behavior, some of which are indicative of the nature and extent of social networks. In addition, multi-level modeling is used to examine whether community level factors mediate the role of gender in drug market activity. 
This document is a research report submitted to the U.S. Department of Justice. This report has not

been published by the Department. Opinions or points of view expressed are those of the author(s)

and do not necessarily reflect the official position or policies of the U.S. Department of Justice.

\section{Women’s Involvement in the Drug Economy}

A considerable body of research has examined the way in which gender structures women’s opportunities to engage in the street-level drug economy (Adler, 1993; Baskin, Sommers, \& Fagan, 1993; Brownstein, Spunt, Crimmins, \& Langley, 1995; Dunlap, Johnson, and Maher, 1997; Fagan, 1994; Griffin \& Armstrong, 2003; Hunt, 1990; Inciardi, Lockwood, \& Pottieger, 1993; Maher \& Curtis, 1992; Maher \& Daly, 1996). Researchers have described a highly sexist and segregated culture, where street-level drug markets often are characterized by well-structured distribution systems operated by men, with women existing only at the lower ranks. Much of this research has been qualitative in design, offering a thick, descriptive analysis of women's participation in particular drug markets within specific neighborhoods or cities.

Researchers have examined drug use by women, focusing on heroin use and the gendered roles associated with involvement in this drug culture (Colten \& Marsh, 1984; Rosenbaum, 1981). Studies have suggested that prostitution was a primary method of drug acquisition, often supplemented by income from other illegal activity (Blom \& van den Berg, 1989; Hunt, 1990; Miller, 1986; Rosenbaum, 1981). More recent research has focused on the changing nature of the drug markets of the 1980's, which according to some researchers has altered dramatically the dynamics and context of women’s involvement in drug use and selling (Fagan, 1994). Much of this change came as a result of the increased availability, and ease of use, of inexpensive cocaine products, as well as the weakening of social bonds that once inhibited women's involvement in the drug trade (see Fagan, 1994 for further discussion). As a result, some scholars have suggested that woman have been afforded expanded job opportunities in this highly lucrative growth market, with "the emergence of women sellers earning high incomes and avoiding prostitution [suggesting] a new dimension to women’s drug involvement” (Fagan, 1994). There 
This document is a research report submitted to the U.S. Department of Justice. This report has not

been published by the Department. Opinions or points of view expressed are those of the author(s)

and do not necessarily reflect the official position or policies of the U.S. Department of Justice.

appears to be little consensus, however, on this point. Other studies have proposee that the growth of the crack cocaine market did not provide increased access to lucrative job opportunities for women. Instead, women continue to be "confined to an increasingly harsh economic periphery,” forced to rely on sex work that offers reduced earning capacities than historically has been available for such work (Maher \& Daly, 1996, p. 486; see also, Murphy \& Rosenbaum, 1997).

A common theme throughout this research is the extent to which women's involvement in the illegal drug industry is influenced by the organization of gender (Adler, 1993; Denton \& O’Malley; Fagan, 1994; Griffin \& Armstrong, 2003; Maher \& Daly, 1996; Wilson, 1993). As is the case in the legitimate world, opportunities in the underworld often are structured according to stereotypical beliefs regarding an individual's capabilities, as well as sex typing of the task at hand (Steffensmeier, 1983). Generally, research has portrayed women’s involvement in the illicit drug trade as minimal, often passive or subordinate, and limited by “male employers’ perceptions of women as unreliable, untrustworthy, and incapable of demonstrating an effective capacity for violence” (Maher \& Daly, 1996, p. 483). Other studies have questioned the accuracy of this limited view, suggesting that these gender differences in participation stem from the historical focus of research on male drug dealers, resulting in "narrowly masculinist conclusions about the nature of the operations, resources, and skills involved in drug dealing” (Denton \& O’Malley, 1999, p. 514). Running counter to traditional assumptions regarding women's participation in the drug trade, some research has provided evidence of women taking on more independent and powerful roles within the street-level drug economy (Denton \& O’Malley; 1999; Morgan \& Joe, 1996; Taylor, 1993). Other researchers have presented a more 
This document is a research report submitted to the U.S. Department of Justice. This report has not

been published by the Department. Opinions or points of view expressed are those of the author(s)

and do not necessarily reflect the official position or policies of the U.S. Department of Justice.

complex view, arguing that women often transition through multiple roles during their

involvement in the drug trade (Mieczkowski, 1994).

\section{Social Networks and Gender}

Regardless of gender, participation in drug market activities requires opportunity and access. Prior research on women's involvement in the drug economy has explored the way in which the gendered nature of the drug trade informs women's opportunities and experiences as both users and dealers (Denton, 2001; Maher, 1997; Murphy \& Arroyo, 2000). Researchers have examined the work roles typically adopted by drug involved women, as well as differing strategies employed by women when participating in drug business hustles, non-drug hustles, and sexwork (Denton \& O’Malley, 1999; Fagan, 1994; Maher, 1997; Maher \& Daly, 1996). Few studies, however, have examined the nature of women's drug trade activity from a social network perspective. Social exchange theories suggest that social and economic exchange "are based on a fundamental feature of social life: much of what we need and value (for example, goods, services, companionship) can only be obtained from others” (Molm, 2001, p.260). Social exchange is governed by one's relationships and location within the social structure. This system of relationships, or social network, is integral to the processes of one's social life. Network ties have been described as "social resources that offer valuable support, acquaintances, and information,” (Moore, 1990, p. 726). To form associations or ties, one must have the opportunity for social contact (Blau, 1977); and this opportunity is enhanced or constrained by one’s place within the social structure.

Studies have explored gender differences in the nature and composition of personal networks. Generally, studies have shown similarity in the size of networks among men and women (Fisher, 1982; Marsden, 1987); however, differences emerged when examining the 
This document is a research report submitted to the U.S. Department of Justice. This report has not

been published by the Department. Opinions or points of view expressed are those of the author(s)

and do not necessarily reflect the official position or policies of the U.S. Department of Justice.

composition of networks. Women's networks tended to be characterized by more ties to kin, while men's networks appeared to include more nonkin or coworkers among their social ties (Fischer \& Oliker, 1983; Wellman, 1985). According to Moore (1990), most gender differences in networks were due to opportunities and constraints arising out of women's and men's different locations in the social structure (p. 734; see also, Fisher \& Oliker, 1983).

Studies examined such salient structural variables as work, family structure, and age, and how these factors influence network ties. For example, researchers have argued that the existence of a job outside the home increases an individual's opportunity to form social ties. Interestingly, studies suggested that structural variables such as marriage and parenthood might have differing effects on men and women and their ability to expand social contacts. For women, marriage and children often act to constrain their ability to increase nonkin social contacts, wherein such circumstances have little bearing on the personal networks formed by men (Fischer \& Oliker, 1983; Gerstel, 1988; Wellman, 1985). Moore (1990) examined the influence of structural variables on the range of network ties and found the effect of gender to be lessened once structural variables were considered. She found that men and women who were similarly situated in terms of family and employment formed similar nonkin networks. At the same time, gender continued to influence the proportion of kin contained within an individual's personal network, with women including "larger proportions of kin as well as more diverse kin types than similarly situated men” (Moore, 1990, p. 733). According to Moore, such results are indicative of the value that society places on women's role as caretakers. Society conditions women to accept the role of nurturer and to be responsive to others, ultimately rewarding their ability to maintain intimate attachments (Steffensmeier \& Allan, 1996). 
This document is a research report submitted to the U.S. Department of Justice. This report has not

been published by the Department. Opinions or points of view expressed are those of the author(s)

and do not necessarily reflect the official position or policies of the U.S. Department of Justice.

Social Networks and Drug Markets

This notion of personal networks and opportunity has been explored in relation to drug market behavior. For example, studies examining the nature of drug markets have incorporated the concept of social networks to propose differing geographical patterns of illicit retail marketplaces. Researchers have suggested social networks as one strategy by which individuals modify the uncertainty and risk associated with their involvement in illegal activities (Eck, 1995; Myhre, 2000). In his development of a model suggesting how buyers and sellers interact to exchange illicit goods and services, Eck (1995) suggested two possible solutions - social networks and routine activities. Social networks act to minimize the risk associated with buying and selling illicit retail goods and services by acting as a screening mechanism. “That is, a buyer knows who the seller is, or knows someone who knows a seller and can vouch for her” (Eck, 1995). Reliance on individuals within one’s network of known purchasers or sellers allows for increased levels of security and communication. A routine activities solution does not rely on a network of contacts to facilitate exchanges. Instead, this approach utilizes the establishment of marketplaces known to both sellers and customers, often locations wherein legitimate activities already take place.

In a similar manner, studies have described typologies of drug markets, noting how certain drug market structures are characterized by the use of social networks in their distribution process (Curtis \& Wendel, 2000). ‘Socially bonded’ or kinship-based drug-distribution enterprises are “usually based upon extra-economic social ties - typically kinship, race, ethnicity, nationality, and/or neighborhood” (Curtis \& Wendel, 2000, p. 133). Such organizations exhibit neither the complexity nor the high degree of division of labor that characterizes 'corporate- 
This document is a research report submitted to the U.S. Department of Justice. This report has not

been published by the Department. Opinions or points of view expressed are those of the author(s)

and do not necessarily reflect the official position or policies of the U.S. Department of Justice.

style’ distributors; however, they have evolved beyond the more fluid structure that typifies

‘freelance distributors’ (Curtis \& Wendel, 2000).

Social Networks and Crime Involved Women

Studies of female criminal activity have highlighted the segregated nature of street life, and the way in which such dynamics “serve to marginalize women’s participation in criminal networks and activities” (Mullins \& Wright, 2003, p. 814; see also Griffin \& Armstrong, 2003; Maher, 1997; Miller, 1986; Steffensmeier, 1983). Findings from these studies suggest a certain consistency in the influence of personal networks on women's involvement in criminal activity. For example, in their study of the dynamics of residential burglary, Mullins and Wright (2003) found that gender norms strongly influenced women's access to criminal networks, thus restricting their opportunity to engage in burglary. Mullins and Wright (2003) noted that males “act as gatekeepers” resistant to the inclusion of women in criminal networks. They observed that, for women, entrée into burglary networks often came as the result of an already existing relationship with a male co-offender. Once this relationship was severed, the woman was less likely to have access to another network, thus reducing her opportunity to engage in crime. In a similar manner, Griffin and Armstrong (2003) found that women living with a husband or boyfriend were more likely to engage in drug dealing, suggesting that involvement in an intimate relationship with a man facilitates access to the drug trade (see also, Adler, 1993; Alarid, Marquart, Burton, Cullen, \& Cuvelier 1996; Koester \& Schwartz, 1993; Murphy et al., 1991; Rosenbaum, 1981).

In one of the few studies to examine the role of social networks among female drug users, Maher (1997) argued that social networks often acted as a survival mechanism, especially for 
poor women. According to Maher (1997),

Women drug users’ networks primarily revolved around exchanges designed to promote income generation, drug use, personal safety, shelter, and companionship. These exchanges were usually characterized by the absence of an expectation of immediate repayment and were often embedded in on-going relationships of some form (p. 36).

Similar to studies of non-criminally-involved women, Maher (1997) found that the women in her study frequently interacted with men, but that "their personal networks were dense and womencentered” (p. 35). The nature and composition of these networks developed as a result of family and work-related factors. Among this group of women drug users, Maher (1997) noted few stable heterosexual intimate relationships. This is supported by other studies that suggest, "the primary relationship that lawbreaking women create is often characterized by a high degree of abuse, violence and exploitation” (O’Brien, 2001, p.87). Maher (1997) also found the composition of women's personal networks was influenced by their involvement in sex work, which resulted in the women spending a great deal of time “out of doors 'hanging out' on the stroll with other women” (p. 35). Finally, while most of these women had children, they did not act as the primary caregiver. Consequently, the women maintained close ties with the non-druginvolved women who cared for their children. In their study of residential burglary, Mullins \& Wright (2003) found similar differentiation in the nature and composition of personal networks along gender lines. They found women's social networks comprised primarily of female friends and relatives, noting that "the female-dominated social networks of friends and relatives comprise the core domestic space and activity for the women in these neighborhoods” (Mullins \& Wright, 834). In contrast, criminal and party networks characterized street-life for the men in the study, with women largely absent. 


\section{Current Study}

As previously noted, much of what is known about women's participation in the drug market comes from ethnographic studies which have provided rich descriptions of the lives of a relatively small number of women drug users within one neighborhood or community (for example, see Adler, 1993; Denton, 2001; Denton \& O’Malley, 1999; Erickson, Butters, McGillicuddy \& Hallgren, 2000; Fagan, 1994; Maher \& Daly, 1996; Rosenbaum, 1981). These studies have suggested a distinctly different mode of drug market participation for women than that of men. In addition, studies of female drug users have noted the influence of social networks and personal contacts on women's opportunities and access to drug markets (Griffin \& Armstrong, 2003). Informed by such research, this study examined specific types of drug acquisition behaviors by male and female drug users, including several drug market behaviors that reflect the nature of an individual's social network. Community-level variables such as racial/ethnic heterogeneity, poverty, and crime have been shown to be important predictors of crime, including drug use and drug distribution (Esbensen \& Huizinga, 1990; Jang \& Johnson, 2001; Skogan, 1990). With this in mind, neighborhood factors and their effects on gender and drug market activities also were examined.

Using data collected from 39 ADAM sites, measures of drug market acquisition behaviors were examined to address two specific research questions. First, what differences exist between men and women’s drug acquisition behaviors? Given the highly gendered nature of the drug trade, and differences in men and women's personal networks, it is expected that significant differences exist in the acquisition behavior of men and women, with female arrestees having fewer resources than male arrestees to obtain drugs, fewer contacts than male arrestees 
within the drug trade, and less mobility than male arrestees when acquiring drugs. With this in mind, the following relationships are hypothesized:

1. Women are less likely than men to have obtained a drug through cash transaction during the past 30 days;

2. Women are more likely than men to have obtained a drug through noncash transaction during the past 30 days;

3. Women are more likely than men to go to a house or apartment to obtain a drug;

4. Women are less likely than men to approach a person in public to obtain a drug;

5. Women are less likely than men to be with the person already when obtaining a drug;

6. Women are less likely than men to purchase a drug directly;

7. Women are more likely than men to use a regular source;

8. Women are more likely than men to purchase a drug indoors;

9. Women are more likely than men to remain in their own neighborhood to purchase a drug;

10. Women are less likely than men to acquire a drug on credit;

11. Women are less likely than men to acquire a drug by being fronted to sell;

12. Women are less likely than men to acquire a drug through trade;

13. Women are more likely than men to acquire a drug in exchange for sex;

14. Women are more likely than men to acquire a drug as a gift;

The second research question examines the importance of community, or area, characteristics. Does the effect of gender in drug market acquisition behaviors vary across community characteristics (e.g., poverty level, female headed households, and racial/ethnic heterogeneity)? Prior studies examining the social forces that shape and alter drug markets have 
noted the importance of the community in which the market is located (Curtis \& Wendel, 2000).

According to Curtis and Wendel (2001), “drug markets are embedded in wide social

environments - neighborhoods and communities - and are responsive to many noneconomic

factors” (p. 145). Forces that shape drug markets include police enforcement strategies, drug

prices, consumer drug preferences, criminal activity, economic resources and job availability, ethnicity, and land use patterns (Curtis \& Wendel, 2001; see also Eck 1995; Loxley, 1998;

McEwen \& Uchida, 2000). As such, it is hypothesized that:

15. Community-level variables will influence, directly and indirectly (through gender), drug market acquisition behaviors.

\section{Methodology}

In order to analyze the role of gender and community characteristics in drug market activity, two data sources were integrated.

Data

Data for this study comes from the Arrestee Drug Abuse Monitoring (ADAM) program from 39 ADAM sites during 2000 - 2003. ${ }^{1}$ Formerly funded by the National Institute of Justice, the ADAM program was created to monitor drug use trends, treatment needs, and at-risk behavior among recently booked arrestees. In 2000, the ADAM program implemented a

\footnotetext{
${ }^{1}$ ADAM sites include New York, Washington, D.C., Portland, San Diego, Indianapolis, Houston, Fort Lauderdale, Detroit, New Orleans, Phoenix, Chicago, Los Angeles, Dallas, Birmingham, Omaha, Philadelphia, Miami, Cleveland, San Antonio, Kansas City, San Jose, Denver, Atlanta, Albuquerque, Minneapolis, Sacramento, Tucson, Anchorage, Des Moines, Laredo, Las Vegas, Oklahoma City, Salt Lake City, Seattle, Spokane, Honolulu, Capital Area, Charlotte-Metro, and Tulsa. These sites collected data at least one quarter during 2000 - 2003. It is important to note that our research focus centers on whether the effect of gender on drug market activity is mediated by community characteristics and not on differences across sites. Thus, we make no assumptions regarding how drug market activity varies from one site to the next. While such a research focus is certainly worthwhile, it is distinctly different from the current examination.
} 
probability sampling plan for male arrestees while female arrestees continued to be incorporated into this program using non-probability sampling schemes. ${ }^{2}$

A new instrument was also implemented in 2000 to capture arrestees’ treatment needs as well as drug market information. Interview data and urine samples were collected within 48 hours of the arrest, providing data on socio-demographics, prior involvement with the criminal justice system, drug dependence and abuse measures, treatment experience(s), drug markets, and self-report and confirmed drug use. It is important to note the variation in response rates across quarters, sites, and years. On average, three-fourths of arrestees who were asked to be interviewed agreed to take part in the study. Sample size varied from site to site due in part to differences in the number of quarterly data collected throughout a given year and barriers associated with weighting of the data. While standardization of data collection was one goal of the revised 2000 ADAM program, there were some deviations from the protocol (e.g., informed consent was ignored, number of potential respondents was counted uniquely) (for a full review of the development of the new instrument, sampling, measurement issues, analyses, see Hunt \& Rhodes, 2001).

In order to incorporate community-level measures to the analyses ${ }^{3}$, arrestees’ residential zip codes were used to link zip code-level data from the 2000 Census (U.S. Bureau of the Census, 2000, Summary Tape File 1 and 3).

\footnotetext{
${ }^{2}$ The probability-based sampling scheme for the adult male arrestees was created to ensure that the male arrestees who were interviewed and tested in each site would be representative of all male arrestees in the county. In order to show that the sample data represents a larger population, the male data can be weighted. Although caution is warranted when making comparisons between male and female arrestees, such concerns center on the accuracy of the point estimates (i.e., representative sample of male arrestees if data are weighted versus non-representative sample of female arrestees). Since the intent of this study is not to make generalizations to the population of arrestees in these counties but rather to conduct an exploratory account on whether drug markets can be classified as "gendered," the non-probability sampling scheme of females is not a serious concern. While there is no way to assess the validity of results of non-probability samples, significance tests are routinely reported in social science research (Oakes, 1986). As such, significance levels for female arrestee analyses have been reported in this report.
} 


\section{Sample}

According to ADAM survey protocol, only those arrestees who indicate they have obtained either marijuana, crack, cocaine, heroin, or methamphetamines in the past 30 days are asked to provide data of drug market activity. Only male and female arrestees who indicated they had obtained either marijuana, crack, cocaine, heroin, or methamphetamines in the past 30 days and who had a valid residential zip code are included in these analyses. The present study consists of 129,189 adult male arrestees and 24,575 female adult arrestees. ${ }^{4}$

\section{Measures}

Given the interest in examining the gender differences in drug market activity, this study relies on various drug market variables of the ADAM data, several of which reflect social network dynamics. For each of the five drug types (i.e., marijuana, crack, cocaine, heroin, and methamphetamines) obtained by arrestees, the following variables are analyzed: cash transaction $^{5}$ (yes=1; no=0), noncash transaction ${ }^{6}$ (yes=1; no=0), cash transaction method of contact $^{7}$ - apartment/house (yes=1; no=0), cash transaction method of contact - approach person in public (yes=1; no=0), cash transactions method of contact - with person already (yes=1;

\footnotetext{
${ }^{3}$ Prior research has empirically measured community-level data of varying geographic areas (e.g., counties, zip codes, and census tracts). In this study, zip code area is used as a proxy for "community." Prior studies of ADAM data have empirically tested the "nested" nature of individual and community-level data by using cities (see Stolzenberg \& D’Alessio, 2002) and zip codes (see Rodriguez, Katz, Schaefer, \& Webb, forthcoming). Certainly, zip codes provide a more precise measure of an area than counties or cities. However, zip codes are still not an ideal community area measure as effects within zip codes can still be masked by such aggregation. Also, the unit of analysis (i.e., arrestee data) of the ADAM program may inherently over-represent certain communities (e.g., high crime, high poverty) and exclude others. While data of a smaller community unit (e.g., address of arrestee) may have been preferred, such data were not available.

${ }^{4}$ As noted in footnote 2, ADAM adult male data contain sampling weights to correct for the unequal probability of selection during data collection. Since we are not interested in the making inference to the arrestees in these ADAM sites, we do not rely on the male data weights. For readers who may be interested in the utilization of ADAM data weights when analyzing nested models, see Rodriguez, Katz, Webb, \& Schaefer (forthcoming) who found that the difference in coefficients and standard errors between the weighted and unweighted models are small and do not change the substantive interpretation of overall findings.

${ }^{5}$ Arrestees were asked whether in the past 30 days they had obtained the drug by paying cash.

${ }^{6}$ Arrestees were asked whether in the past 30 days they had obtained the drug without paying cash.

${ }^{7}$ Reponses to cash transaction method of contact reflect arrestees' last transaction.
} 
no=0), purchase drug directly ${ }^{8}$ (yes=1; no=0), regular source ${ }^{9}$ (yes=1; no=0), purchase indoors $^{10}$ (yes $=1 ;$ no=0), purchase in neighborhood ${ }^{11}$ (yes=1; no=0), noncash transaction

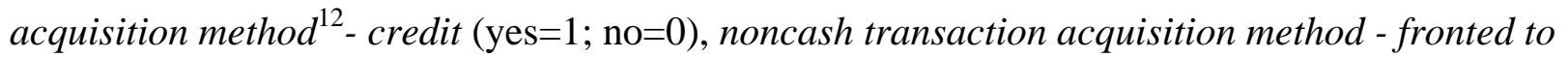
sell (yes=1; no=0), noncash transaction acquisition method - trade (yes=1; no=0), noncash transaction acquisition method- sex (yes=1; no=0), noncash transaction acquisition method - gift

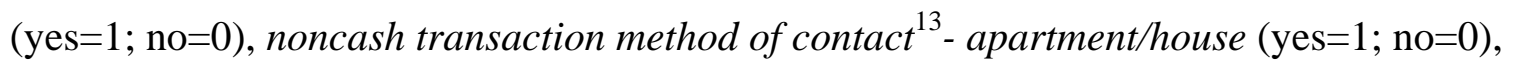
noncash transaction method of contact - approach person in public (yes=1; no=0), noncash transactions method of contact - with person already (yes=1; no=0). As shown, drug transactions are captured for two different time frames, that is, during the past 30 days and last transaction

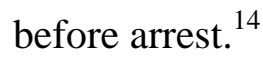

Predictors at the individual-level include gender (male=1; female=0), race/ethnicity (dummy coded variables for Hispanic/Latinos, Blacks, Native Americans, and Asians with Whites as the omitted category) and age at time of arrest. Measures of high school graduation (yes=1; no=0), unemployment status (unemployed=1; employed=0), and marital status (married=1; not married=0) are also analyzed. Legal factors are measured by the inclusion of most serious offense at arrest (violent offense $=1$; non-violent offense $=0$ ) and prior incarceration (yes=1; no=0).

Three community-level measures were derived from Census data. Poverty level captures the percent of population with an income below the poverty level. Female headed households

\footnotetext{
${ }^{8}$ Reponses reflect arrestees' last transaction.

${ }^{9}$ Reponses reflect arrestees' last transaction.

${ }^{10}$ Reponses reflect arrestees' last transaction.

${ }^{11}$ Reponses reflect arrestees' last transaction.

${ }^{12}$ Reponses to noncash transaction acquisition method reflect arrestees’ last transaction.

${ }^{13}$ Reponses to noncash transaction method of contact reflect arrestees' last transaction.

${ }^{14}$ It is unknown whether the last drug transaction before arrest represents a representative account of drug transactions. For example, certain behaviors are more likely to lead to an arrest and therefore, the transactions associated with these behaviors are likely overrepresented. Given this, the inferential and descriptive results may reflect a non-representative account of drug transactions.
} 
represent the percent of multi-person households with a female head of household. A measure of racial and ethnic heterogeneity (Blau, 1977) was computed based upon racial/ethnic proportions of the population for each zip code:

$$
\begin{gathered}
\text { Racial and Ethnic Heterogeneity }=1-\left[\left(\mathrm{P}_{\text {White }}\right)^{2}+\left(\mathrm{P}_{\text {Hispanic }}\right)^{2}+\left(\mathrm{P}_{\text {Black }}\right)^{2}+\left(\mathrm{P}_{\text {American }}\right.\right. \\
\text { Indian })^{2}+\left(\mathrm{P}_{\text {Hawaiian or Pacific Islander }}\right)^{2}+\left(\mathrm{P}_{\text {Asian }}\right)^{2}+\left(\mathrm{P}_{\text {Multi- }}\right. \\
\text { racial/ethnic } \left.)^{2}+\left(\mathrm{P}_{\text {Other }}\right)^{2}\right]
\end{gathered}
$$

This measure varies between 0 and 1, with higher values indicating greater racial/ethnic heterogeneity.

Table 1 presents the dependent and independent variables used in the analyses along with the corresponding coding scheme.

\section{Analytical Strategy}

Male and female samples were first combined to examine the effect of gender in the various drug market indicators followed by gender specific models to establish whether the effect of gender in drug market activity varied across community characteristics. This produced a total of 85 models for the combined samples, 66 models for females, and 80 models for males. $^{15}$

Given the nested structure of the data (i.e., arrestees within zip codes), a hierarchical modeling technique was used to analyze the data. Multi-level models allow for an examination of both individual and community-level effects on the dependent variable (Raudenbush \& Bryk, 2002). Since the dependent variables are non-linear and dichotomous in nature - hierarchical generalized linear models (HGLM) are used to estimate the impact of individual (Level 1) and community-level (Level 2) factors on the various drug market dependent variables.

\footnotetext{
${ }^{15}$ Only cases with sufficient cell counts in the dependent variable were analyzed.
} 
In order to determine whether the mean of the dependent variables varied across communities (i.e., zip codes), an intercepts-only model was first estimated. A significant random effects component for the intercept indicates that the rate of the dependent variable varies across zip codes. If the random effects component for the intercept was significant $(p<.01)$, then individual and community-level measures were included as predictors. First, a randomcoefficient model including only the individual-level measures was estimated followed by a model incorporating the community-level measures. If the random effects component for the intercept was not significant, only the individual-level measures were analyzed given the expected constant effect of the dependent variable across communities. See Appendix A for description of the HGLM models.

\section{Findings}

\section{Description of Female Arrestees}

Female arrestee data show that among the racial/ethnic groups under examination, Whites represent the largest proportion of arrestees across four of the five drugs, followed by Blacks, Hispanic/Latinos, Native Americans, and Asians ${ }^{16}$ (see Table 2). Specifically, Whites represent the largest proportion of arrestees who acquired marijuana, cocaine, heroin, and methamphetamines while Black females comprised the largest proportion (52\%) of arrestees who obtained crack. The average age of females ranged from 29 years old among those that acquired marijuana to 35 years old among those that acquired crack. The majority of females in the sample were high school graduates, employed, and not married. Females who obtained marijuana were more likely to have been arrested for a violent offense (17\%) than those females who obtained crack, (10\%), cocaine (11\%), heroin (6\%), or methamphetamines (13\%). Over seventy percent of female arrestees had a history of prior incarceration.

\footnotetext{
${ }^{16}$ Given the small number of Asian female arrestees, they were excluded from the HGLM analyses.
} 
Among the five drugs examined, a significant proportion of females reported acquiring certain drugs through cash transactions. For example, of the females who reported acquiring heroin in the past 30 days prior to their arrest, 85\% reported at least one cash transaction. Also, of the females who acquired crack in the past 30 days, $81 \%$ reported at least one cash transaction. Analyses show that of the females who reported acquiring marijuana and methamphetamines, $82 \%$ reported at least one noncash transaction. Over twenty percent of females who acquired marijuana, crack, or methamphetamines reported going to an apartment/house to contact the person from whom they purchased the drugs. Approximately a third of females who obtained crack (37\%) and heroin (38\%) indicated they approached someone in public to buy these drugs. A much smaller proportion of females reported being with the person as the method of contact for cash transactions. Specifically, less than ten percent of females who obtained crack, cocaine, and heroin reported being with the person while, ten percent of females who obtained marijuana and twelve percent of females who obtained methamphetamines reported being with that person.

Over seventy-five percent of females reported purchasing the drugs directly themselves and a majority of females indicated they purchased drugs through their regular source. Of the females who reported acquiring marijuana or cocaine, approximately $60 \%$ reported making an indoor purchase. Also, among females who obtained methamphetamines, $77 \%$ reported making an indoor purchase. The majority of indoor purchases were reported among females who obtained marijuana (60\%), cocaine (59\%), and methamphetamines (77\%). With the exception of females who obtained crack, the majority of females reported purchasing their drugs outside of their neighborhood. 
Among noncash transactions, a smaller proportion of females reported going to an apartment/house (14\% - 18\%) or approaching person in public $(8 \%-22 \%)$ as the method of contacting the person from whom they obtained their drugs. Not surprisingly, a much larger proportion of females reported being with the person as the method of contact (31\% - 59\%). The most reported method of acquisition for noncash transactions was having received the drug as a gift. For example, over three fourth of females who obtained marijuana (91\%), cocaine (79\%), and methamphetamines (81\%) reported receiving these drugs as a gift.

The Level 2 (i.e., community-level data) descriptive statistics represent the average value across zip codes (unweighted for number of residents). These statistics indicate that the average percent of the population living below the poverty level was $19 \%$ for females who obtained marijuana and cocaine, $15 \%$ for females who obtained methamphetamines, and $21 \%$ for females who obtained crack and heroin. The female headed households measure revealed that the average female headed households rate of community members across zip codes was lowest for females who obtained methamphetamines (14\%) and highest among females who obtained crack (19\%) and heroin (19\%). The average rate of racial/ethnic heterogeneity across communities was as high as .49 for females who obtained methamphetamines and as low as .43 for females who obtained heroin. ${ }^{17}$

\section{Description of Male Arrestees}

Male data reveal that the largest proportion of arrestees who obtained cocaine, heroin, and methamphetamines were White. Black males represented the largest proportion of arrestees who reported obtaining marijuana and crack (see Table 3). ${ }^{18}$ The average age of male arrestees

\footnotetext{
${ }^{17}$ The pearson correlation coefficients of Level 2 data indicate that communities with high levels of racial/ethnic heterogeneity were also high in poverty level $(r=.31, \mathrm{p}<.05)$ and in female headed households $(r=.39$, $\mathrm{p}<.05)$. Also, communities with a high poverty level were also high in female headed households $(r=.41, \mathrm{p}<.05)$.

${ }^{18}$ Given the small number of Asian male arrestees, they were excluded from the HGLM analyses.
} 
ranged from 28 years old among those who acquired marijuana to 36 years old among those that acquired crack. Similar to the female sample, the majority of males were high school graduates, employed, and not married. A larger proportion of males than females were arrested for a violent offense and had a history of prior incarceration.

Among the five drugs examined, the majority of males report acquiring the drugs through cash transactions. In fact, for four of the five drugs (i.e., marijuana, cocaine, heroin, and methamphetamines), the proportion of males who acquired these drugs through cash transactions was higher than for females who obtained the same drugs. Also, the proportion of males who obtained marijuana, crack, cocaine, and methamphetamines through noncash transactions was smaller than females who obtained these drugs. Consistent with the female sample, of the males who reported acquiring marijuana, crack, and methamphetamines, over twenty percent reported going to an apartment/house as the method of contacting the person from whom they purchased the drugs. A larger proportion of males than females approached someone in public to buy marijuana (33\% versus $25 \%$ ), crack (43\% versus $36 \%$ ), cocaine (24\% versus $17 \%)$, heroin (41\% versus $38 \%$ ), and methamphetamines (11\% versus $7 \%)$. Less than ten percent of males who obtained crack, cocaine, and heroin reported the method of contact as being with the person. Also, ten percent of males who obtained marijuana and methamphetamines reported being with the person.

Over eighty-three percent of males reported purchasing the drugs directly. These proportions are higher than those reported in the female sample. Similar to the female descriptives, the majority of males indicated they purchased the drug through a regular source; however, the proportions across drugs were much smaller than those of the female sample. Among the males who reported obtaining marijuana and cocaine, approximately fifty percent 
This document is a research report submitted to the U.S. Department of Justice. This report has not

been published by the Department. Opinions or points of view expressed are those of the author(s)

and do not necessarily reflect the official position or policies of the U.S. Department of Justice.

reported purchasing these drugs indoors. Also, among the males who reported acquiring

methamphetamines, 71\% indicated making an indoor purchase. Once again, these proportions are smaller than those of the female sample. With regard to purchases in the neighborhood, the majority of males reported purchasing all five drugs outside of their neighborhood.

Noncash transaction findings show that a slightly larger proportion of males than females reported going to an apartment/house $(16 \%$ - 20\%) or approaching a person in public (10\% 26\%) as the method of contact. Also, a smaller proportion of males than females indicated being with the person as the method of contact. Consistent with the female sample, the most reported method of acquisition for noncash transactions was having received the drug as a gift. However, the proportions of males are smaller than those of the females for marijuana (85\% versus 91\%), crack (62\% versus 79\%), heroin (61\% versus 66\%), and methamphetamines (73\% versus 81\%) noncash transactions.

The descriptives of Level 2 data for males are fairly consistent with those of the females. The community-level data statistics show that the average percent of the population living below the poverty level was $19 \%$ for males who obtained marijuana and cocaine, $15 \%$ for males who obtained methamphetamines, and 21 - 22\% for males who obtained crack and heroin. The female headed households measure revealed that the average female headed households rate of community members across zip codes was lowest for males who obtained methamphetamines (13\%) and highest among males who obtained heroin (19\%). The average rate of racial/ethnic heterogeneity across communities was as high as .48 for males who obtained methamphetamines and as low as .44 for males who obtained heroin. ${ }^{19}$

\footnotetext{
${ }^{19}$ The pearson correlation coefficients of Level 2 data indicate that communities with high levels of racial/ethnic heterogeneity were also high in poverty level $(r=.33, \mathrm{p}<.05)$ and in female headed households $(r=.40, \mathrm{p}<.05)$. Communities with a high poverty level were also high in female headed households $(r=.43, \mathrm{p}<.05)$.
} 
This document is a research report submitted to the U.S. Department of Justice. This report has not

been published by the Department. Opinions or points of view expressed are those of the author(s)

and do not necessarily reflect the official position or policies of the U.S. Department of Justice.

\section{Gender Differences in Drug Acquisition Behavior}

In order to establish whether drug market activity is influenced by gender, HGLM analyses of the 17 dependent variables for each of the five drugs was conducted. After controlling for socio-demographic variables, legal criteria, and variables known to impact the effect of gender based on a social networks framework (e.g., marital status and employment status), findings show that gender has a significant effect in particular drug market activity. Table 4 presents a summary of the gender effects of the models (see Appendix B for a full presentation of the Level 1 and 2 effects of the models).

Analyses reveal that males were more likely than females to acquire three of the five drugs (i.e., marijuana, cocaine, and methamphetamines) through cash transactions. Conversely, females were more likely than males to acquire four of the five drugs (i.e., marijuana, crack, cocaine, and methamphetamines) through noncash transactions. Findings of the method of contact for cash transactions show that females were more likely than males to go to an apartment/house to purchase crack while less likely than males to approach a person in public when purchasing four of the five drugs. Further, females were also more likely than males to purchase drugs (i.e., marijuana, crack, and cocaine) from their regular source, purchase all five drugs indoors, and purchase drugs (i.e., marijuana and crack) in their neighborhood.

Noncash transaction findings show that males were more likely than females to acquire four of the five drugs by credit, fronting to sell, or trading drugs or property/merchandise. Females, on the other hand, were more likely than males to report acquiring the drugs by trading sex and by receiving the drugs as a gift. Consistent with the cash transactions findings, males were more likely than females to approach a person in public to obtain four of the five drugs through noncash transactions. Males were also less likely than females to report being with the 
This document is a research report submitted to the U.S. Department of Justice. This report has not

been published by the Department. Opinions or points of view expressed are those of the author(s)

and do not necessarily reflect the official position or policies of the U.S. Department of Justice.

person when acquiring four of the five drugs. Lastly, males were more likely than females to go to an apartment/house to obtain methamphetamines.

Gender Specific Models - Females’ Drug Acquisition Behavior and Community Characteristics

Our second research objective was to determine whether the effect of gender in drug market activity was mediated by community characteristics (i.e., poverty level, female headed households, and racial/ethnic heterogeneity). Table 5 contains a summary of the effects of poverty level for the female sample (see Appendix C for a full presentation of the Level 1 and 2 effects of the models). Among those models where the mean rate of the dependent variable varied across communities, poverty level was significant in 5 models. The rate of poverty level of communities had a positive effect on approaching a person in public to purchase marijuana, indicating that females from communities with a higher percentage of residents who live below the poverty level were more likely to approach a person in public to purchase marijuana. Interestingly, the effect of poverty level is not constant across drug types. For example, poverty level had a negative effect in marijuana indoor purchases yet a positive effect in heroin indoor purchases. Lastly, female arrestees who reside in communities characterized by high poverty levels were more likely to purchase marijuana and crack in their neighborhood.

Table 6 contains a summary of the effects of the community variable female headed households. Findings show that females who live in communities with a higher percentage of female headed households were more likely to purchase marijuana through cash transactions. On the other hand, females who live in communities with a lower percentage of female headed households were more likely to obtain marijuana and crack through noncash transactions. With regard to method of contact, females who live in communities with a lower percentage of female headed households were more likely to go to an apartment/house to purchase crack while 
females who live in communities with a higher percentage of female headed households were more likely to approach a person in public to purchase marijuana, crack, and heroin. Female headed households had a negative effect in marijuana, crack, and heroin indoor purchases and a positive effect in marijuana neighborhood purchases.

The third community level variable, racial/ethnic heterogeneity, only had a significant influence in noncash transactions (see Table 7). Specifically, females who reside in communities with a higher percentage of racial and ethnic composition were more likely to acquire marijuana through noncash transactions.

\section{Gender Specific Models - Males’ Drug Acquisition Behavior and Community Characteristics}

Male findings show a significant number of models where the mean rate of the dependent variable varied across communities. ${ }^{20}$ Table 8 represents a summary of the effects of poverty level for the male sample (see Appendix D for a full presentation of the Level 1 and 2 effects of the models). The poverty level of communities had a positive effect on going to an apartment/house and approaching a person in public to purchase three of the five drugs (i.e., marijuana, crack, and cocaine), indicating that males from communities with a higher percentage of residents who live below the poverty level were more likely to go to an apartment/house or approach a person in public to purchase these drugs. Also, male arrestees who live in communities with lower poverty rates were more likely to be with the person already when buying marijuana. Consistent with the female findings, poverty level had a negative effect in marijuana indoor purchases and a positive effect in purchases made within the neighborhood.

\footnotetext{
${ }^{20}$ The difference between male and female findings in relation to the variation of the dependent variable across zip codes may be attributed to a much smaller female sample size relative to males or to the uniquely different effect of these community variables in drug market acquisition for males and females. While we are unable to ascertain why the effects in the dependent variable varied more in the male models, findings show that among those community variables that are significant across male and female samples, the effects are fairly consistent.
} 
Among males’ noncash transactions, males who live in high poverty areas were more likely to approach a person in public to acquire three of the five drugs (i.e., marijuana, crack, and heroin).

Findings show that males who live in communities with a higher percentage of female headed households were more likely to purchase marijuana and crack through cash transactions (see Table 9). Findings of noncash transactions show that males who live in communities with a lower percentage of female headed households were more likely to obtain four of the five drugs (i.e., marijuana, crack, cocaine, and heroin) through noncash transactions. Males who live in communities with a lower percentage of female headed households were more likely to go to an apartment/house to purchase marijuana and more likely to be with the person already when purchasing marijuana. Also, males who live in communities with a higher percentage of female headed households were more likely to approach a person in public to purchase four of the five drugs (i.e., marijuana, crack, cocaine, and heroin). Consistent with the female findings, female headed households had a negative effect in indoor drug purchases (i.e., marijuana, crack, cocaine, and heroin) and a positive effect in neighborhood drug purchases (i.e., marijuana and crack). Among males' noncash transactions, males who live in communities with a low proportion of female headed households were more likely to receive crack as a gift. Males who live in communities characterized by high female headed households were more likely to approach a person in public to acquire three of the five drugs (i.e., marijuana, crack, and heroin) and less likely to go to an apartment/house or be with the person already when acquiring marijuana.

Racial/ethnic heterogeneity had a negative effect in marijuana and cocaine cash transactions while a positive effect in marijuana noncash transactions (see Table 10). Specifically, males who reside in communities with a higher percentage of racial and ethnic 
composition were less likely to acquire marijuana and cocaine through cash transactions and more likely to acquire marijuana through noncash transactions. Males who live in communities characterized by high racial and ethnic composition were also less likely to go to an apartment/house to contact the person from who they purchased marijuana and cocaine yet more likely to approach a person in public to purchase marijuana and crack. Racial/ethnic heterogeneity had a negative effect in drug purchases made indoors (i.e., marijuana, cocaine, and methamphetamines) and a positive effect in drug purchases made within the neighborhood (i.e., marijuana, heroin, and methamphetamines). Consistent with cash transactions, approaching the person in public to acquire marijuana and crack through noncash transactions was positively influenced by racial/ethnic heterogeneity. Lastly, males who live in communities with a high racial/ethnic make-up were less likely to be with the person when obtaining marijuana through noncash transactions.

\section{Discussion}

This study provides a comparative assessment of male and female arrestees’ drug market acquisition behaviors, utilizing ADAM survey data collected from thirty-nine sites. Specifically, this study examined differences in men and women's efforts to obtain drugs and whether the effect of gender in drug market activity was mediated by community characteristics. Findings from this study support prior research that suggests participation in drug markets by women and men differs significantly (Denton \& O’Malley, 1999; Fagan, 1994; Maher, 1997; Maher \& Daly, 1996). Additionally, these findings highlight the importance of examining the dynamics of acquisition activities by drug type (Riley, 1997). This study also adds to existing research which emphasizes the value of incorporating community level factors when assessing the way in which individuals engage in drug market activity (Katz, Webb, Rodriguez, \& Schaefer, 2005). In 
This document is a research report submitted to the U.S. Department of Justice. This report has not

been published by the Department. Opinions or points of view expressed are those of the author(s)

and do not necessarily reflect the official position or policies of the U.S. Department of Justice.

addition, it is important to note that even after controlling for structural variables such as marital status and employment status, two variables that have been found to significantly influence social networks (Moore, 1990), the effect of gender on drug acquisition behavior remained, suggesting that similarly situated male and female arrestees rely on different strategies to obtain drugs.

\section{Gender Differences in Drug Acquisition Behavior}

In general, the findings suggested that male and female arrestees employ different strategies when obtaining drugs, strategies that appear to reflect the gendered culture of street level drug markets and the influence of personal networks on women's involvement in criminal activity. For example, when participating in noncash transactions, male arrestees were more likely than female arrestees to acquire drugs on credit, by fronting to sell, and by trading drugs and/or merchandise. Certainly such noncash transactions require a level of trust between buyer and seller, as well as access to drugs and/or property with which to trade, most of which is found within criminal networks and often unavailable to women (Mullins \& Wright, 2003). Non-cash transactions require a belief on the part of the seller that the buyer is 'good' for the money or will not step off with the drugs. These findings support the notion that woman often are limited in their ability to engage in drug transactions due to perceptions that women are unreliable, untrustworthy, and unable to handle the violence that is endemic to the drug trade (Fagan, 1994; Maher \& Daly, 1996).

In addition, when engaging in a cash transaction, female arrestees were more likely than male arrestees to purchase drugs from a regular source, purchase drugs indoors, and remain within their neighborhood when making the purchase. The women in this sample also were less likely to make contact with a seller in public. When examined within the context of prior studies 
This document is a research report submitted to the U.S. Department of Justice. This report has not

been published by the Department. Opinions or points of view expressed are those of the author(s)

and do not necessarily reflect the official position or policies of the U.S. Department of Justice.

on women and drugs, a social network perspective provides a useful framework within which to understand the effect of gender on drug market transactions. For example, why were female arrestees more likely than male arrestees to rely on a regular source when purchasing marijuana, crack, and cocaine? Social network research suggests that while similar in size, the nature and composition of personal networks differ by gender (Fisher \& Oliker, 1983;Moore, 1990; Wellman, 1985). Women’s networks tend to be more kin oriented; men’s networks tend to include more ties to non-kin and co-workers. Perhaps this greater variety of social ties represents a broader array of potential drug sources. Indeed, this interpretation is consistent with prior studies that have described the segregated nature of street life, and women's limited access to drug and crime networks (Griffin \& Armstrong, 2003; Maher, 1997; Mullin \& Wright, 2003).

These findings also point to the risk-reducing value of personal networks. As noted previously, social networks are one strategy by which individuals may modify the uncertainty and risk associated with their involvement in illegal activities (Eck, 1995; Myhre, 2000).

Reliance on individuals within one's network of known purchasers or sellers allows for increased levels of security and communication, especially among women. This need to rely on personal networks was made evident in Murphy and Arroyo’s (2000) study of women’s roles as consumers of illegal drugs. According to one of the women interviewed, "There was just certain people that I always dealed with 'cause you never know what you was buying. It could be soap or macadamia nuts. They sell all kinds of stuff” (Murphy \& Arroyo, 2000, p.106). For women, the ability to minimize risk may be especially critical since women are often viewed as easy targets, less likely than men to rely on violence when physically or verbally victimized, or when sold "gaffle or bunk" or other fraudulent drugs (Murphy \& Arroyo, 2000, p.106). According to Maher (1997), 
in the context of a 'culture of terror' characterized by male-dominated street networks which claim drug distribution and sales as boys’ own turf, women who use the streets to sell or buy drugs are subject to constant harassment and are regularly victimized (p. 95). Taken together, such dynamics highlight the importance of trust in illicit drug exchanges and the value of utilizing fewer, ostensibly more reliable, drug sources.

Also suggestive of the influence of personal networks is the finding that female arrestees were more likely than male arrestees to remain in the neighborhood when purchasing marijuana and crack. Women, as compared to men, may have less opportunity to leave the immediate neighborhood to purchase crack and marijuana due to domestic responsibilities. Social network studies suggest that domestic constraints limit network ties, perhaps resulting in the minimization of both opportunity and access to drug sources outside the neighborhood.

Interestingly, gender did not influence the likelihood of an arrestee purchasing drugs directly (through cash transaction). Perhaps having the cash resources to purchase drugs mediates the effect of gender. In addition, the effect of gender on methods of contact was not consistent across cash and noncash transactions. Taken together, these findings raise the issue of the significance of resources, highlighting the need to explore the differing dynamics of drug acquisition behavior across type of transaction (i.e., cash versus noncash).

Again, it is important to note that the effects of gender across drug market acquisition behaviors were as expected. These effects, however, were not constant across drug type. This finding is consistent with prior studies that have noted the manner in which drug markets "differ substantially from one another...including how users buy and consume drugs” (Riley, 1997, p. 2; see also Curtis \& Wendel, 2000). For example, compared to acquisition behaviors associated with marijuana, crack, cocaine, and methamphetamines, fewer significant differences exist 
This document is a research report submitted to the U.S. Department of Justice. This report has not

been published by the Department. Opinions or points of view expressed are those of the author(s)

and do not necessarily reflect the official position or policies of the U.S. Department of Justice.

between male and female arrestees in their efforts to obtain heroin. These data do not allow us to explore in any depth the source of such differences in acquisition behavior by drug type. These findings do, however, emphasize the importance of developing detailed information regarding the dynamics of specific drug markets for use by policymakers and service providers.

\section{Drug Acquisition Behavior and Community Characteristics}

The second research objective was to examine whether the effect of gender in drug acquisition behavior was mediated by community characteristics (i.e., poverty level, female headed households, and racial/ethnic heterogeneity). In general, this study found the effects of community characteristics on efforts to obtain drugs to be similar for men and women, although the effects of the community were significant for men across more drug types. The data suggest that in poorer communities and in communities with a higher percentage of female headed households, male and female arrestees engaged in acquisition behaviors that were characteristic of open drug markets. For example, both male and female arrestees living in communities characterized by higher levels of poverty were more likely to approach person in public, to purchase drugs in their own neighborhood, and less likely to obtain drugs indoors. While the effects of female headed households across male and female samples were fairly consistent, it is important to note that the percentage of female headed households in a community had a significant effect on male noncash transactions where such effects were not found in the analyses

of female arrestees. In addition, the racial/ethnic heterogeneity of the community had a greater influence on the acquisition behaviors of men than on those of women. Thus it would appear that measures of community characteristics may be more important for men than for women's drug acquisition behaviors. However, as previously noted, the difference between male and female findings in relation to the variation of the dependent variable across zip codes may also 
be attributed to a much smaller female sample size. While unable to ascertain whether female sample size had an effect in how community-level factors influenced drug market indicators, findings show that the significant community variables were fairly consistent across male and female samples.

Additionally, it is important to note that not all community measures affected arrestees’ efforts to obtain in a similar manner. For example, the percentage of female headed households impacted the likelihood of cash and noncash transactions. The level of poverty within a community, however, did not. Such findings illustrate the need to examine various community level data and not assume that measures of social disadvantage have the same effect across drug market indicators. Although we were unable to analyze other important community-level measures such as crime rates and price of illicit drugs, we believe such measures should also be examined and not assumed to have the same affect across all drug transactions.

Finally, it is critical to note the differing patterns across type of drug. As discussed previously, for female arrestees, poverty level had a negative effect in marijuana indoor purchases, yet a positive effect in heroin indoor purchases. This is important as it shows how gender, poverty, and drug type are interrelated rather than independent in drug acquisitions, and that drug markets remain particularly distinct.

\section{Policy Implications}

Findings from this study highlight several important policy implications. First, these analyses underscore the value of developing detailed information regarding the dynamics of specific drug markets for use by policymakers and service providers. Variation in drug acquisition behaviors across drug type would suggest that strategies to identify and intervene in drug acquisition behaviors might be more effective when tailored to specific drug markets. In a 
similar manner, this study raises questions regarding consequences associated with current enforcement strategies. Given the way in which acquisition behaviors vary by gender and drug type, some individuals are at an increased risk for arrest and official intervention, specifically those individuals who engage in drug acquisition behavior in open, public areas. For law enforcement agencies, these findings suggest the need for developing alternative approaches to identify drug-involved individuals who may be missed with traditional policing techniques. Finally, this study supports other research that has noted the significance relationship between personal networks and drug use. For example, Schroeder, Latkin, Hoover, Curry, Knowlton, \& Celentano (2001) found that illicit drug use within one’s personal network significantly influenced continued drug use. Understanding the role of social networks and their influence on an individual's involvement in the drug market can provide critical insight into the development and implementation of drug intervention strategies.

\section{Conclusion}

Arguably, the nature of gender differences in drug market behaviors may well be explained by the differing composition of men and women's social network, as well as the highly gendered nature of the street-level drug economy. As noted previously, participation in drug market activities requires opportunity and access. According to a social network perspective, gender differences in personal networks "arise in part from dissimilar social structural locations of men and women, which lead to distinct opportunities for and constraints on the formation of close personal ties” (Moore, 1990, p. 726). Granted, the data do not permit direct analysis of specific network characteristics such as composition, depth, or density. We believe, however, that several acquisition variables provide insight into the nature of an individual's social network and thus allow us to begin to explore the gendered role of social networks in drug acquisition 
behavior, and the way in which the context of the community mediates such relationships.

Researchers have noted the importance of these relationships, arguing that "substance users are not passive responders to their social environments...social skills and coping strategies affect the degree to which 'high-risk’ social environment results in increased substance use” (Schroeder et al., 2001). Future research should continue to explore the influence of community conditions on the development and functioning of social networks, as well as their affect on drug market indicators. 


\section{References}

Adler, P. (1993). Wheeling and dealing: An ethnography of an upper-level drug dealing and smuggling community. New York: Columbia University Press.

Alarid, L., Marquart, J., Burton, V., Cullen, F. \& Cuvelier, J. (1996). Women’s roles in serious offenses: A study of adult felons. Justice Quarterly, 13, 431-454.

Baskin, D., Sommers, I., \& Fagan, J. (1993). The political economy of violent female street crime. Fordham Urban Law Journal, 20, 401-407.

Blau, P. M. (1977). Inequality and heterogeneity: A primitive theory of social structure. New York: Free Press.

Blom, M. and van den Berg, T. (1989). A typology of the life and work styles of "heroin prostitutes.” In (ed. M. Cain) Growing up good: Policing the behavior of girls in Europe. London: Sage.

Brownstein, J. Spunt, B., Crimmins, S. and Langley, S. (1995) Woman who kill in drug market situations. Justice Quarterly, 12, 473-498.

Chesney-Lind, M. (1997). The female offender: Girls, women, and crime. Thousand Oaks, CA:Sage.

Colten, M. and Marsh, J. (1984). A sex roles perspective on drug and alcohol use by women. In C.S. Widom (Ed.), Sex Roles and Psychopathology. New York: Plenum Press.

Curtis, R. and Wendel, T. (2000). Toward the development of a typology of illegal drug markets. In R. Clarke (Ed.), Crime prevention studies, volume 11 (pp. 121-152). Monsey, New York: Criminal Justice Press.

Denton, B. (2001). Dealing: Women in the drug economy. Sydney: UNSW Press. 
Denton, B. and O’Malley, P. (1999). Gender, trust and business: Women drug dealers in the illicit economy. British Journal of Criminology, 39, 513-530.

Dunlap, E. Johnson,B.D., and Maher, L. (1997). Female crack sellers in New York City: Who they are and what they do. Woman and Criminal Justice, 8, 25-55.

Eck, J. (1995). A general model of the geography of illicit retail marketplaces. In J. Eck \& D. Weisburd (Eds.), Crime and place, crime prevention studies, volume 4 (pp. 67-93). Monsey, New York: Criminal Justice Press.

Erickson, P., Butters, J., McGillicuddy, P. \& Hallgren, A. (2000). Crack and prostitution: Gender, myths, and experiences. Journal of Drug Issues, 30, 4, 767-788.

Esbensen, F. and Huizinga, D. (1990). Community structure and drug use: From a social disorganization perspective. Justice Quarterly, 7, 4, 691-709.

Fagan, J. (1994). Women and drugs revisited: Female participation in the cocaine economy. Journal of Drug Issues, 24, 179-227.

Fischer, C. (1982). To dwell among friends. Chicago: University of Chicago.

Fischer, C. and Oliker, S. (1983). A research note on friendship, gender, and the life cycle. Social Forces, 62, 124-132.

Gerstel, N. (1988). Divorce, gender and social integration. Gender and Society, 2, 343-367.

Griffin, M. and Armstrong, G. (2003). The effect of local life circumstances on female probationer offending. Justice Quarterly, 20, 2, 213-239.

Hunt, L. (1990). Drugs and consensual crimes: Drug dealing and prostitution. In M. Tonry \& J.Q. Wilson (eds.) Drugs and crime. Chicago: University of Chicago Press.

Hunt, D. \& Rhodes, W. (2001). Methodology Guide for ADAM. Washington ,DC: National Institute of Justice. 
Inciardi, J., Lockwood D., and Pottieger, A. (1993). Women and crack cocaine. New York: MacMillan.

Jang, S.J. and Johnson, B.R. (2001). Neighborhood disorder, individual religiosity, and adolescent use of illicit drugs: a test of multilevel hypothesis. Criminology, 39, 109-143.

Katz, C., Webb, V., Rodriguez, N. and Schaefer, D. (2005). Examining the impact of individual, community, and market factors on methamphetamine use: A tale of two cities: Final Report. Washington, DC: National Institute of Justice.

Koester, S. and Schwartz, J. (1993). Crack, gangs, sex, and powerlessness: A view from Denver. In Mitchell S. Ratner (Ed.), Crack Pipe as Pimp: An Ethnographic Investigation of Sexfor-crack Exchanges. New York: Lexington Books.

Loxley, W. (1998). Weed or speed? Convicted drug dealers' views of substitutions in the western Australian illicit drug market to 1992. International Journal of Drug Policy, 9, 109-118.

Maher, L (1997). Sexed work: Gender, race, and resistance in a Brooklyn Drug Market. New York: Clarendon Press.

Maher, L. and Curtis, R. (1992). Women on the edge of crime: Crack cocaine and the changing contexts of street-level sex work in New York City. Crime, Law, and Social Change, 18, 221-258.

Maher, L. and Daly K. (1996). Women in the street-level drug economy: Continuity or change? Criminology, 34, 465-491.

Marsden, P. (1987). Core discussion networks of Americans. American Sociological Review, 52, 122-131. 
Maxwell, S. and Maxwell, C. (2000). Examining the "criminal careers" of prostitutes within the nexus of drug use, drug selling, and other illicit activities. Criminology, 38, 787-809.

McEwen, T. and Uchida, C.D. (2000). An evaluation of the COPS Office Methamphetamine Initiative: Interim report. Alexandria, VA: Institute for Law and Justice.

Mieczkowski, T. (1994). The experiences of women who sell crack. The Journal of Drug Issues, 24, 227-248.

Miller, E. (1986). Street woman. Philadelphia: Temple University Press.

Molm, L. (2001).Theories of social exchange and exchange networks. In George Ritzer and Barry Smart (Eds.) The handbook of social theory (pp. 260-272). Thousand Oaks, CA: Sage Press.

Moore, G. (1990). Structural determinants of men’s and women’s personal networks. American Sociological Review, 55, 726-735.

Morgan, P. and Joe, K. (1996). Citizens and outlaws: The private lives and public lifestyles of women in the illicit drug economy. Journal of Drug Issues, 26, 1, 125-141.

Mullins, C. and Wright, R. (2003). Gender, social networks, and residential burglary. Criminology, 41, 813-840.

Murphy, S. and Arroyo, K. (2000). Women as judicious consumers of drug markets. In R. Clarke (Ed.), Crime prevention studies, volume 11 (pp. 101-120). Monsey, New York: Criminal Justice Press.

Murphy S., Waldorf, D., and Reinarman, C. (1991). Drifting into dealing: Becoming a cocaine seller. Qualitative Sociology, 13, 321-343. 
Murphy, S. and Rosenbaum, M. (1997). Two women who used cocaine too much: Class, race, gender, crack and coke. In C. Reinarman \& H. Levine (eds.) Crack in America: Demons drugs and social justice. Berkeley, CA: University of California Press.

Myhre, M. (2000). Drug market precipitators: Situational dynamics of open-air drug markets in public housing. Unpublished doctoral dissertation, Rutgers, The State University of New Jersey.

Oakes, M. (1986). Statistical inference: A commentary for social and behavioral sciences. NY: Wiley.

O’Brien, P. (2001). Making it in the “free world.” Albany, NY: State University of New York Press.

Riley, K. (1997). Crack, powder cocaine, and heroin: Drug purchase and use patterns in six U.S. cities. Washington, DC: Office of National Drug Control Policy.

Rodriguez, N., Katz, C., Webb. V., \& Schaefer, D. (forthcoming). Examining the impact of individual, community, and market factors on methamphetamine use: A tale of two cities. Journal of Drug Issues.

Rosenbaum, M. (1981). Women on heroin. New Brunswick, N.J.: Rutgers University Press. Schroeder, J.R., Latkin, C.A., Hoover, D.R., Curry, A.D., Knowlton, A.R., and Celentano, D.D. (2001). Illicit drug use in one’s social network and in one’s neighborhood predicts individual heroin and cocaine use. Annals of Epidemiology, 11, 389-394.

Skogan, W.G. (1990). Disorder and decline: Crime and the spiral of decay in American neighborhoods. New York: Free Press 
Sommers, I. and Baskin, D. (1996). The structural relationship between drug use, drug dealing, and other income support activities among women drug sellers. Journal of Drug Issues, 26, 975-1007.

Steffensmeier, D. (1983). Organization properties and sex-segregation in the underworld: Building a sociological theory of sex differences in crime. Social Forces, 61, 10101032.

Steffensmeier, D. \& Allan, E. (1996). Gender and crime: Toward a gendered theory of female offending. Annual Review of Sociology, 22, 459-487.

Stolzenberg, L. and D’Alessio, S.J. (2002). A multilevel analysis of the effect of cocaine price on cocaine use among arrestees. Journal of Criminal Justice, 31, 185-195.

Taylor, A. (1993). Women and drug users: An ethnography of a female injecting community. Oxford: Clarendon Press.

Wellman, B. (1985). Domestic work, paid work and net work. In S. Duck and D. Perlman (Eds.), Understanding personal relationships (pp. 159-191). London: Sage.

Wilson, N. K. (1993). Stealing and dealing: The drug war and gendered criminal opportunity. In C. Culliver (ed.) Female criminality: The state of the art (pp. 169-194). New York: Garland Publishing, Inc. 
Table 1: Coding Scheme

\section{Individual-Level Data}

Dependent Variables

Cash Transaction

Noncash Transaction

Cash Transaction Method of Contact

Apartment/house

Approach person in public

With person already

Purchase Drug Directly

Regular Source

Purchase Indoors

Purchase in Neighborhood

Noncash Transaction Acquisition Method

Credit

Fronted to sell

Trade

Sex

Gift

Noncash Transaction Method of Contact

Apartment/house

Approach person in public

With person already

Independent Variables

Gender

Race/ethnicity

White

Black

Hispanic/Latino

Native American

Age

High School Graduate

Marital Status

Employment Status

Most Serious Arrest Charge

Prior Incarceration

\section{Community-Level Data}

Poverty Level

Female headed Households
Yes $=1 ; \mathrm{No}=0$

$\mathrm{Yes}=1 ; \mathrm{No}=0$

Yes $=1 ; \mathrm{No}=0$

$\mathrm{Yes}=1 ; \mathrm{No}=0$

$\mathrm{Yes}=1 ; \mathrm{No}=0$

Yes $=1 ; \mathrm{No}=0$

Yes $=1 ; \mathrm{No}=0$

Yes $=1 ; \mathrm{No}=0$

Yes $=1 ; \mathrm{No}=0$

Yes $=1 ; \mathrm{No}=0$

Yes $=1 ; \mathrm{No}=0$

Yes $=1 ; \mathrm{No}=0$

Yes $=1 ; \mathrm{No}=0$

Yes $=1 ; \mathrm{No}=0$

Yes $=1 ; \mathrm{No}=0$

Yes $=1 ; \mathrm{No}=0$

Yes $=1 ; \mathrm{No}=0$

Males $=1$; Females $=0$

Separate dummy variables for race/ethnicity; Whites are reference category

Age at arrest

Yes $=1 ;$ No $=0$

Married $=1$; Not Married $=0$

Unemployed $=1$; Employed $=0$

Violent offense $=1$; Non-violent offense $=0$

Yes $=1 ; \mathrm{No}=0$

$\%$ of population with income below the poverty level

$\%$ of multi-person household with female head of household Racial/ethnic heterogeneity measure 
This document is a research report submitted to the U.S. Department of Justice. This report has not

been published by the Department. Opinions or points of view expressed are those of the author(s)

and do not necessarily reflect the official position or policies of the U.S. Department of Justice.

Table 2. Frequencies of Female Arrestees Who Reported Acquiring a Particular Drug

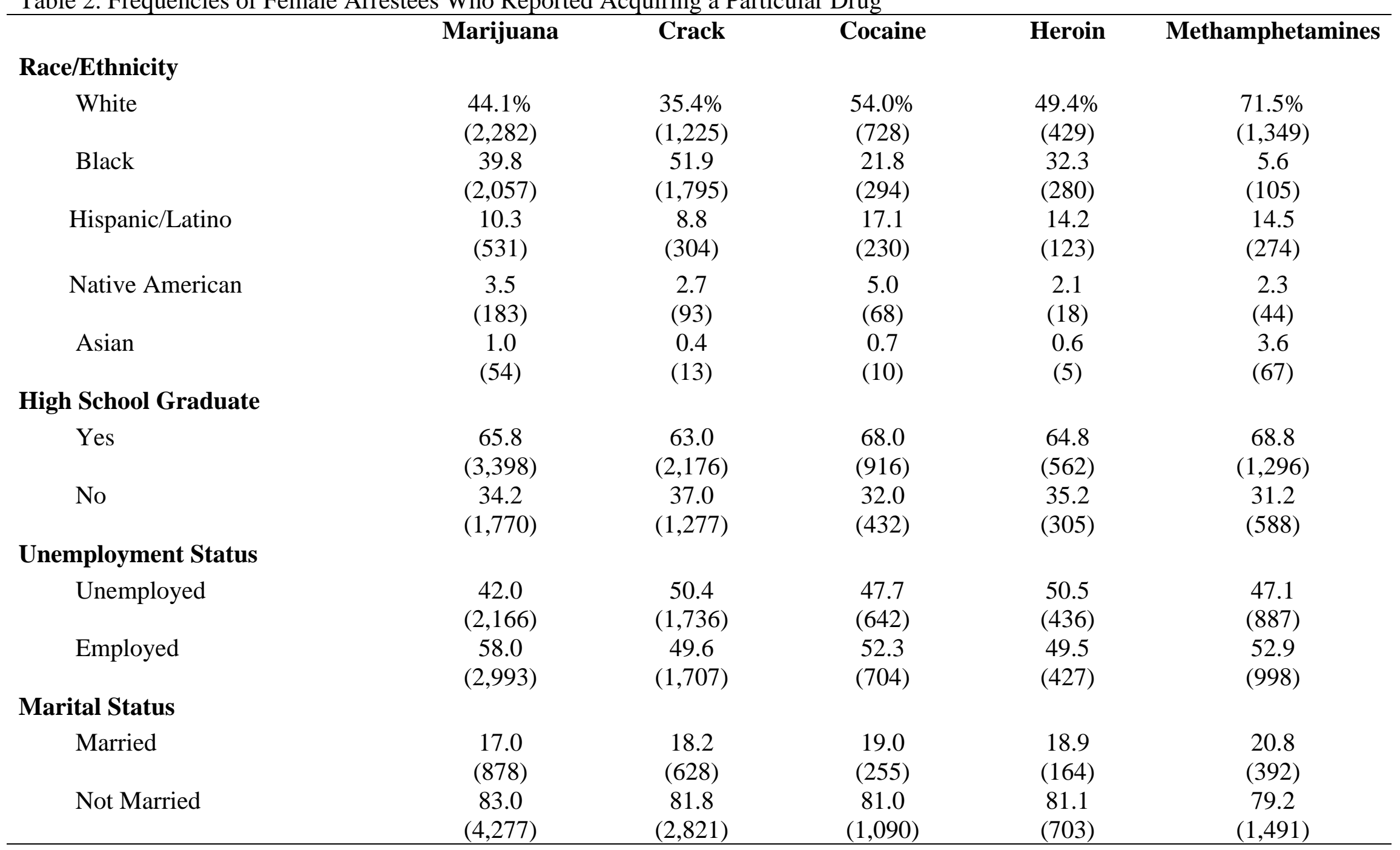


This document is a research report submitted to the U.S. Department of Justice. This report has not

been published by the Department. Opinions or points of view expressed are those of the author(s)

and do not necessarily reflect the official position or policies of the U.S. Department of Justice.

Table 2. Frequencies of Female Arrestees Who Reported Acquiring a Particular Drug (cont.)

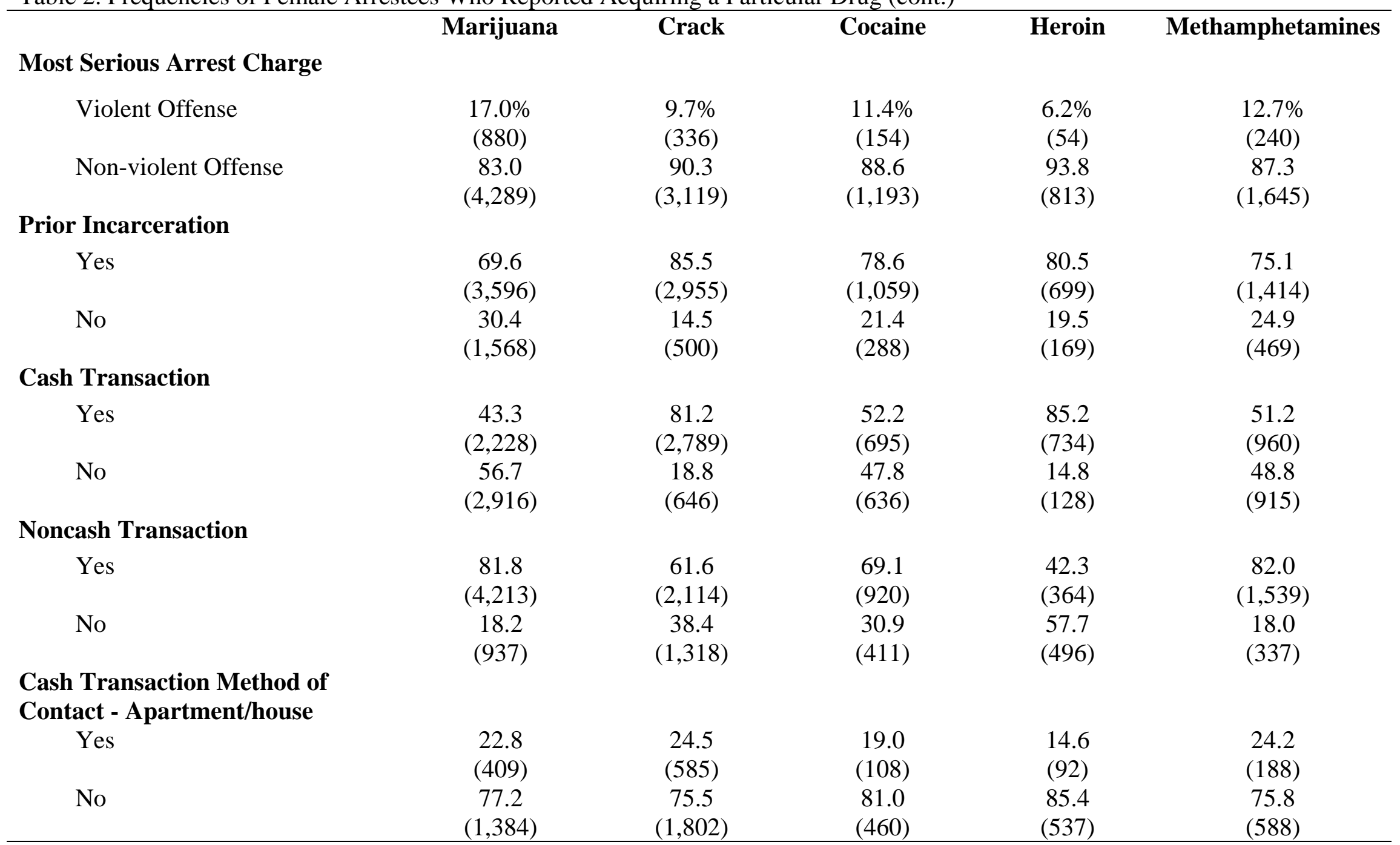


This document is a research report submitted to the U.S. Department of Justice. This report has not

and do not necessarily reflect the official position or policies of the U.S. Department of Justice.

Table 2. Frequencies of Female Arrestees Who Reported Acquiring a Particular Drug (cont.)

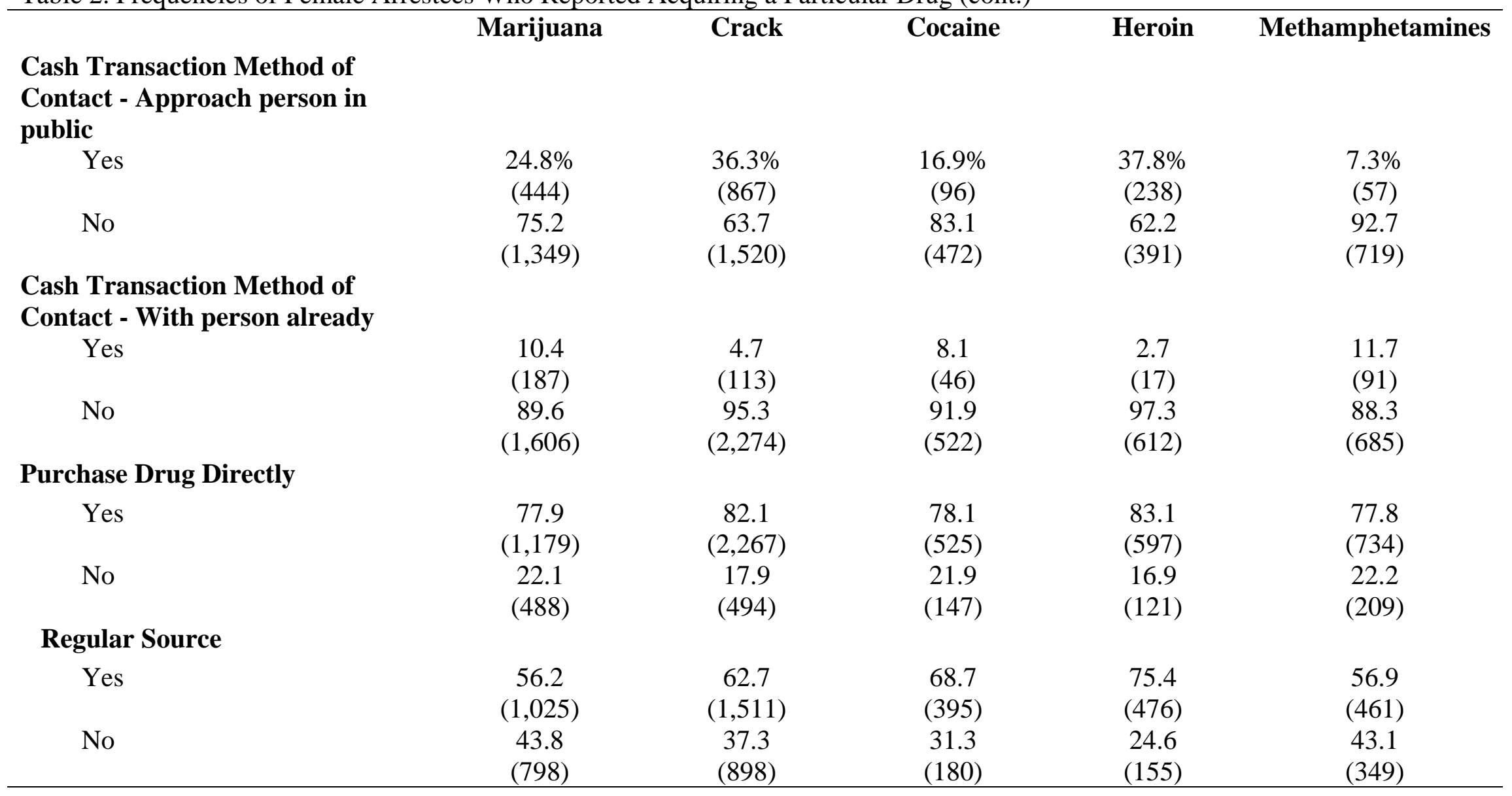


This document is a research report submitted to the U.S. Department of Justice. This report has not

and do not necessarily reflect the official position or policies of the U.S. Department of Justice.

Table 2. Frequencies of Female Arrestees Who Reported Acquiring a Particular Drug (cont.)

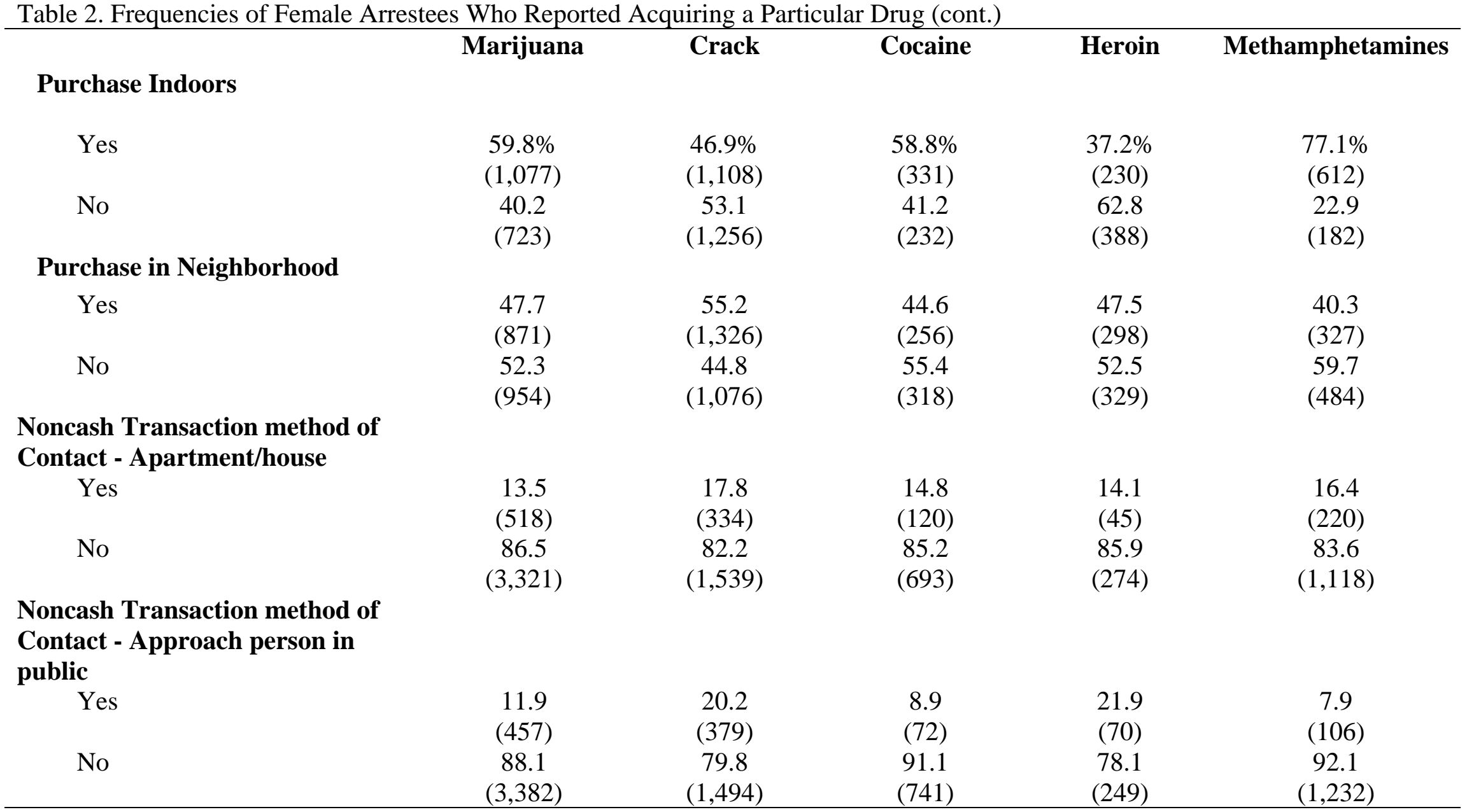


This document is a research report submitted to the U.S. Department of Justice. This report has not been published by the Department. Opinions or points of view expressed are those of the author(s)

and do not necessarily reflect the official position or policies of the U.S. Department of Justice.

Table 2. Frequencies of Female Arrestees Who Reported Acquiring a Particular Drug (cont.)

\begin{tabular}{|c|c|c|c|c|c|}
\hline & Marijuana & Crack & Cocaine & Heroin & Methamphetamines \\
\hline \multicolumn{6}{|c|}{$\begin{array}{l}\text { Noncash Transaction method of } \\
\text { Contact - With person already }\end{array}$} \\
\hline Yes & $\begin{array}{l}59.0 \% \\
(2,264)\end{array}$ & $\begin{array}{c}36.9 \% \\
(692)\end{array}$ & $\begin{array}{c}53.5 \% \\
(435)\end{array}$ & $\begin{array}{l}30.1 \% \\
(96)\end{array}$ & $\begin{array}{c}50.7 \% \\
(678)\end{array}$ \\
\hline No & $\begin{array}{c}41.0 \\
(1,575)\end{array}$ & $\begin{array}{c}63.1 \\
(1,181)\end{array}$ & $\begin{array}{c}46.5 \\
(378)\end{array}$ & $\begin{array}{c}69.9 \\
(223)\end{array}$ & $\begin{array}{c}49.3 \\
(660)\end{array}$ \\
\hline \multicolumn{6}{|c|}{$\begin{array}{l}\text { Noncash Transaction Method of } \\
\text { Acquisition }\end{array}$} \\
\hline On Credit & $\begin{array}{c}4.0 \\
(154)\end{array}$ & $\begin{array}{l}15.3 \\
(290)\end{array}$ & $\begin{array}{c}7.2 \\
(59)\end{array}$ & $\begin{array}{l}15.7 \\
(49)\end{array}$ & $\begin{array}{c}5.4 \\
(73)\end{array}$ \\
\hline Fronted to Sell & $\begin{array}{l}1.5 \\
(56)\end{array}$ & $\begin{array}{c}4.5 \\
(86)\end{array}$ & $\begin{array}{c}3.4 \\
(28)\end{array}$ & $\begin{array}{c}4.5 \\
(14)\end{array}$ & $\begin{array}{c}3.8 \\
(52)\end{array}$ \\
\hline Trade & $\begin{array}{c}2.9 \\
(111)\end{array}$ & $\begin{array}{c}7.0 \\
(133)\end{array}$ & $\begin{array}{l}4.7 \\
(39)\end{array}$ & $\begin{array}{c}9.3 \\
(29)\end{array}$ & $\begin{array}{c}7.9 \\
(107)\end{array}$ \\
\hline Sex & $\begin{array}{l}1.0 \\
(37)\end{array}$ & $\begin{array}{l}11.1 \\
(210)\end{array}$ & $\begin{array}{c}5.2 \\
(43)\end{array}$ & $\begin{array}{c}5.0 \\
(16)\end{array}$ & $\begin{array}{c}1.5 \\
(21)\end{array}$ \\
\hline Gift & $\begin{array}{c}90.5 \\
(3,406)\end{array}$ & $\begin{array}{c}62.0 \\
(1,173)\end{array}$ & $\begin{array}{c}79.4 \\
(653)\end{array}$ & $\begin{array}{c}65.5 \\
(205)\end{array}$ & $\begin{array}{c}81.4 \\
(1,105)\end{array}$ \\
\hline Age & $\begin{array}{c}\text { Mean }=29.18 ; \\
\text { S.D. }=8.76\end{array}$ & $\begin{array}{c}\text { Mean }=34.77 ; \\
\text { S.D. }=8.01\end{array}$ & $\begin{aligned} \text { Mean } & =31.27 ; \\
\text { S.D. } & =8.42\end{aligned}$ & $\begin{aligned} \text { Mean } & =34.12 ; \\
\text { S.D. } & =9.02\end{aligned}$ & $\begin{array}{c}\text { Mean = 30.32; } \\
\text { S.D. 8.22 }\end{array}$ \\
\hline Poverty Level & $\begin{array}{c}\text { Mean }=.19 ; \\
\text { S.D. }=.11\end{array}$ & $\begin{array}{c}\text { Mean }=.21 ; \\
\text { S.D. }=.11\end{array}$ & $\begin{array}{c}\text { Mean }=.19 \\
\text { S.D. }=.10\end{array}$ & $\begin{array}{c}\text { Mean }=.21 ; \\
\text { S.D. }=.11\end{array}$ & $\begin{array}{c}\text { Mean }=.15 ; \\
\text { S.D. }=.09\end{array}$ \\
\hline Female headed Household & $\begin{aligned} \text { Mean } & =.18 \\
\text { S.D. } & =.09\end{aligned}$ & $\begin{array}{c}\text { Mean }=.19 ; \\
\text { S.D. }=.09\end{array}$ & $\begin{array}{c}\text { Mean }=.16 ; \\
\text { S.D. }=.07\end{array}$ & $\begin{aligned} \text { Mean } & =.19 ; \\
\text { S.D. } & =.10\end{aligned}$ & $\begin{array}{c}\text { Mean }=.14 ; \\
\text { S.D. }=.05\end{array}$ \\
\hline Racial/ethnic Heterogeneity & $\begin{array}{c}\text { Mean }=.46 ; \\
\text { S.D. }=.17\end{array}$ & $\begin{array}{c}\text { Mean }=.45 \\
\text { S.D. }=.18\end{array}$ & $\begin{array}{c}\text { Mean }=.46 ; \\
\text { S.D. }=.16\end{array}$ & $\begin{array}{c}\text { Mean }=.43 \\
\text { S.D. }=.19\end{array}$ & $\begin{array}{c}\text { Mean }=.49 ; \\
\text { S.D. }=.16\end{array}$ \\
\hline
\end{tabular}


This document is a research report submitted to the U.S. Department of Justice. This report has not

been published by the Department. Opinions or points of view expressed are those of the author(s)

and do not necessarily reflect the official position or policies of the U.S. Department of Justice.

Table 3. Frequencies of Male Arrestees Who Reported Acquiring a Particular Drug

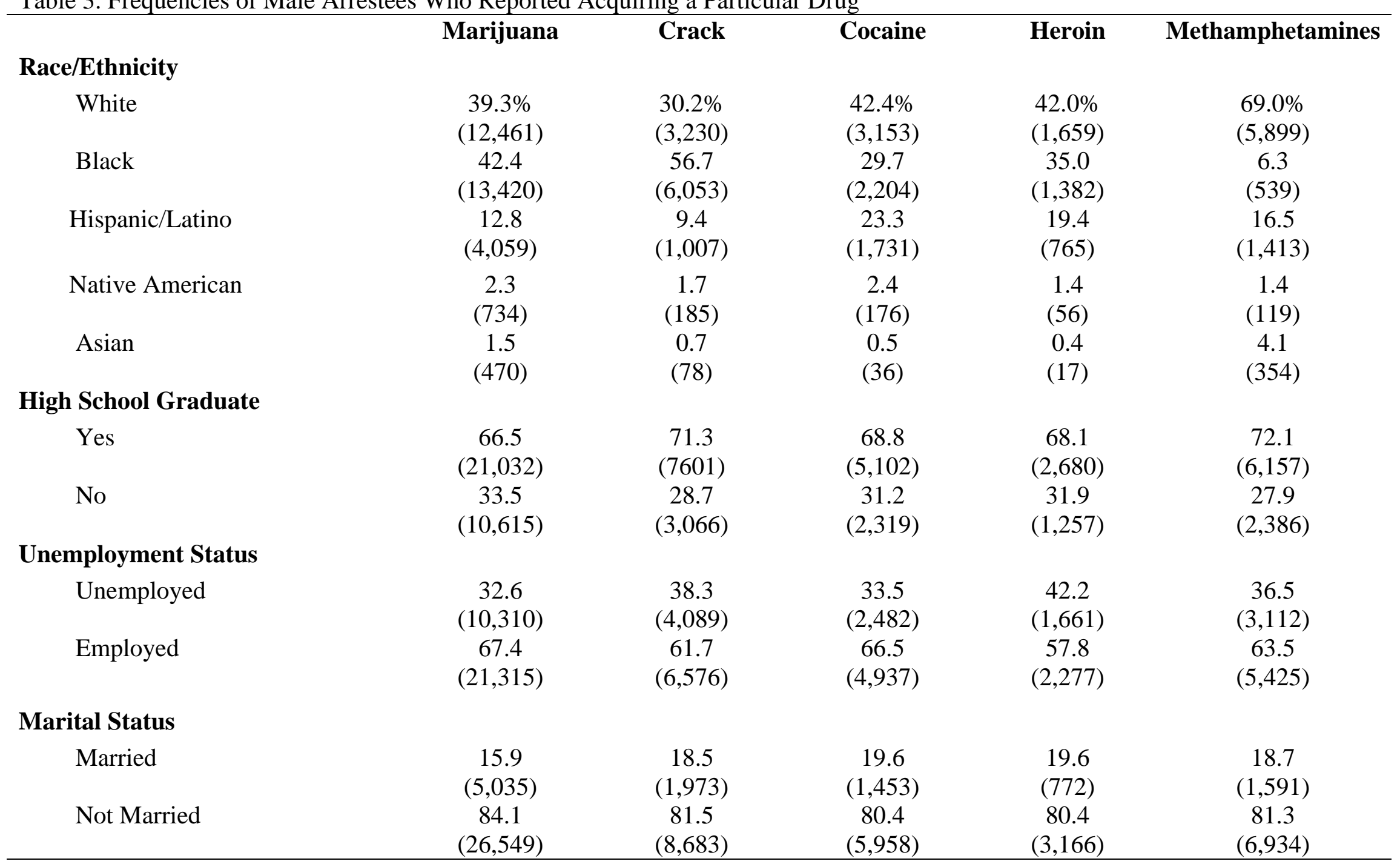


This document is a research report submitted to the U.S. Department of Justice. This report has not been published by the Department. Opinions or points of view expressed are those of the author(s)

and do not necessarily reflect the official position or policies of the U.S. Department of Justice.

Table 3. Frequencies of Male Arrestees Who Reported Acquiring a Particular Drug (cont.)

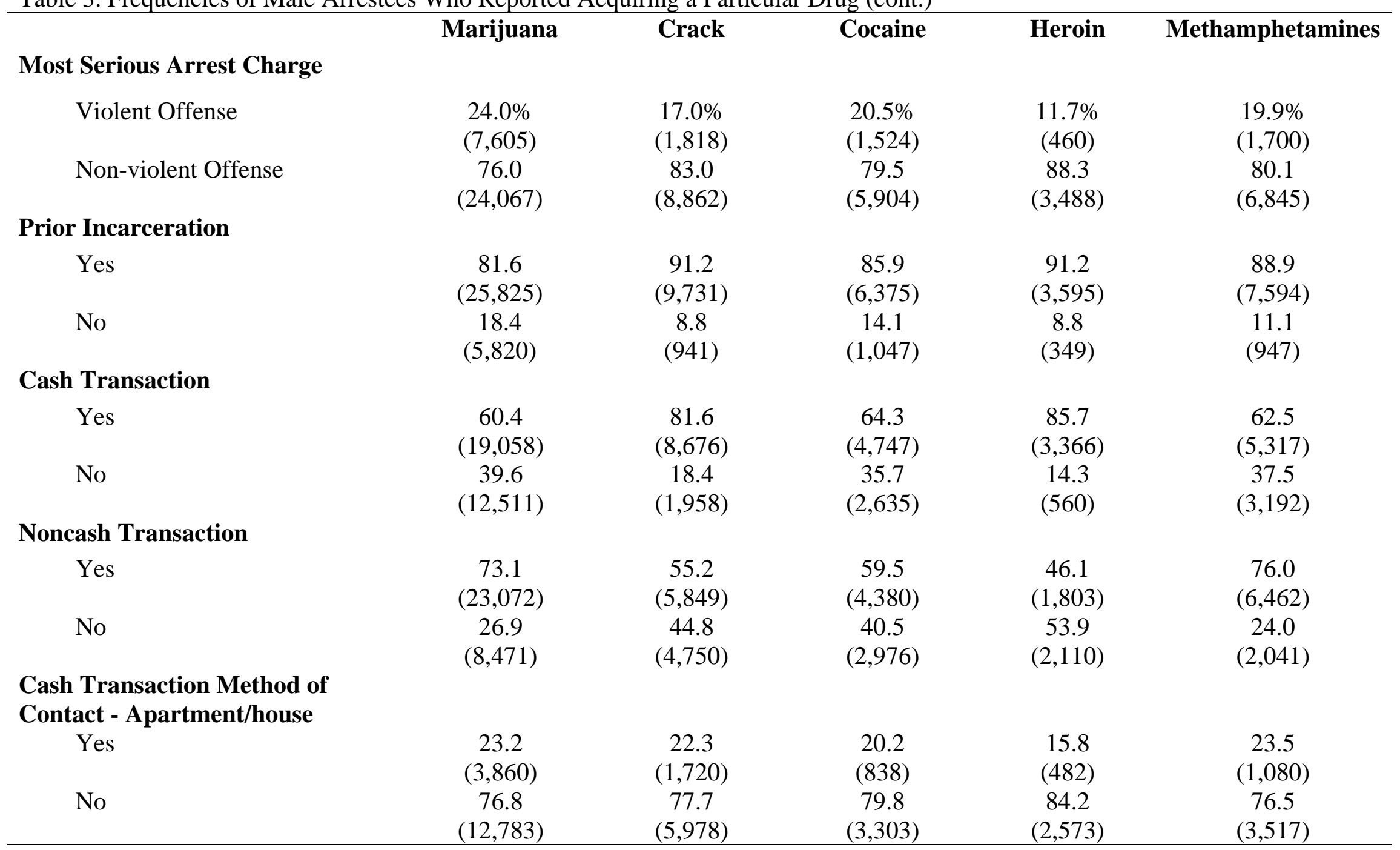


This document is a research report submitted to the U.S. Department of Justice. This report has not

and do not necessarily reflect the official position or policies of the U.S. Department of Justice.

Table 3. Frequencies of Male Arrestees Who Reported Acquiring a Particular Drug (cont.)

\begin{tabular}{|c|c|c|c|c|c|}
\hline 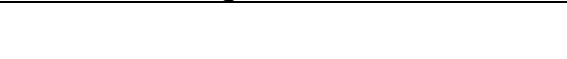 & Marijuana & Crack & Cocaine & Heroin & Methamphetamines \\
\hline \multicolumn{6}{|l|}{$\begin{array}{l}\text { Cash Transaction Method of } \\
\text { Contact - Approach person in } \\
\text { public }\end{array}$} \\
\hline Yes & $\begin{array}{l}32.8 \% \\
(5,457)\end{array}$ & $\begin{array}{l}43.2 \% \\
(3,323)\end{array}$ & $\begin{array}{l}24.3 \% \\
(1,007)\end{array}$ & $\begin{array}{l}40.8 \% \\
(1,245)\end{array}$ & $\begin{array}{l}11.2 \% \\
(517)\end{array}$ \\
\hline No & $\begin{array}{c}67.2 \\
(11,186)\end{array}$ & $\begin{array}{c}56.8 \\
(4,375)\end{array}$ & $\begin{array}{c}75.7 \\
(3,134)\end{array}$ & $\begin{array}{c}59.2 \\
(1,810)\end{array}$ & $\begin{array}{c}88.8 \\
(4,080)\end{array}$ \\
\hline \multicolumn{6}{|l|}{$\begin{array}{l}\text { Cash Transaction Method of } \\
\text { Contact - With person already }\end{array}$} \\
\hline Yes & $\begin{array}{c}10.1 \\
(1,675)\end{array}$ & $\begin{array}{c}4.0 \\
(311)\end{array}$ & $\begin{array}{c}7.7 \\
(317)\end{array}$ & $\begin{array}{c}3.0 \\
(93)\end{array}$ & $\begin{array}{c}10.1 \\
(464)\end{array}$ \\
\hline No & $\begin{array}{c}89.9 \\
(14,968)\end{array}$ & $\begin{array}{c}96.0 \\
(7,387)\end{array}$ & $\begin{array}{c}92.3 \\
(3,824)\end{array}$ & $\begin{array}{c}97.0 \\
(2,962)\end{array}$ & $\begin{array}{c}89.9 \\
(4,133)\end{array}$ \\
\hline \multicolumn{6}{|l|}{ Purchase Drug Directly } \\
\hline Yes & $\begin{array}{c}85.3 \\
(16,171)\end{array}$ & $\begin{array}{c}85.1 \\
(7,314)\end{array}$ & $\begin{array}{c}83.9 \\
(3,910)\end{array}$ & $\begin{array}{c}88.3 \\
(2,922)\end{array}$ & $\begin{array}{c}82.5 \\
(4,342)\end{array}$ \\
\hline No & $\begin{array}{c}14.7 \\
(2,790)\end{array}$ & $\begin{array}{c}14.9 \\
(1,277)\end{array}$ & $\begin{array}{c}16.1 \\
(753)\end{array}$ & $\begin{array}{c}11.7 \\
(386)\end{array}$ & $\begin{array}{c}17.5 \\
(924)\end{array}$ \\
\hline \multicolumn{6}{|l|}{ Regular Source } \\
\hline Yes & $\begin{array}{c}48.2 \\
(8,131)\end{array}$ & $\begin{array}{c}51.2 \\
(3,975)\end{array}$ & $\begin{array}{c}60.9 \\
(2,545)\end{array}$ & $\begin{array}{c}68.6 \\
(2,108)\end{array}$ & $\begin{array}{c}56.2 \\
(2,642)\end{array}$ \\
\hline No & $\begin{array}{c}51.8 \\
(8,727)\end{array}$ & $\begin{array}{c}48.8 \\
(3,794)\end{array}$ & $\begin{array}{c}39.1 \\
(1,637)\end{array}$ & $\begin{array}{c}31.4 \\
(964) \\
\end{array}$ & $\begin{array}{c}43.8 \\
(2,062)\end{array}$ \\
\hline
\end{tabular}


This document is a research report submitted to the U.S. Department of Justice. This report has not

and do not necessarily reflect the official position or policies of the U.S. Department of Justice.

Table 3. Frequencies of Male Arrestees Who Reported Acquiring a Particular Drug (cont.)

Marijuana Crack Cocaine

\section{Purchase Indoors}

$\begin{array}{lccccc}\text { Yes } & 50.9 \% & 41.3 \% & 50.2 \% & 32.9 \% & 71.2 \% \\ & (8,505) & (3,183) & (2,072) & (1,001) & (3,301) \\ \text { No } & 49.1 & 58.7 & 49.8 & 67.1 & 28.8 \\ & (8,216) & (4,521) & (2,056) & (2,038) & (1,338)\end{array}$

Yes

No

Noncash Transaction method of

Contact - Apartment/house

$\begin{array}{lcc}\text { Yes } & 15.7 & 19.0 \\ & (3,237) & (947) \\ \text { No } & 84.3 & 81.0 \\ & (17,439) & (4,029)\end{array}$

Noncash Transaction method of Contact - Approach person in public

$\begin{array}{ccc}\text { Yes } & 16.6 & 26.4 \\ & (3,436) & (1,313) \\ \text { No } & 83.4 & 73.6 \\ & (17,240) & (3,663)\end{array}$

$\begin{array}{ccccc}43.3 & 47.8 & 41.7 & 47.8 & 40.1 \\ (7,320) & (3,720) & (1,745) & (1,465) & (1,885) \\ 56.7 & 52.2 & 58.3 & 52.2 & 59.9 \\ (9,581) & (4,055) & (2,436) & (1,603) & (2,819)\end{array}$

15.8

16.2

83.8

20.1

(616)

$(3,294)$

$(1,380)$

79.9

$(4,434)$

59.9

$(2,819)$ 
This document is a research report submitted to the U.S. Department of Justice. This report has not been published by the Department. Opinions or points of view expressed are those of the author(s)

and do not necessarily reflect the official position or policies of the U.S. Department of Justice.

Table 3. Frequencies of Male Arrestees Who Reported Acquiring a Particular Drug (cont.)

\begin{tabular}{|c|c|c|c|c|c|}
\hline & Marijuana & Crack & Cocaine & Heroin & Methamphetamines \\
\hline \multicolumn{6}{|c|}{$\begin{array}{l}\text { Noncash Transaction method of } \\
\text { Contact - With person already }\end{array}$} \\
\hline Yes & $\begin{array}{c}50.4 \% \\
(10,421)\end{array}$ & $\begin{array}{c}31.1 \% \\
(1,550)\end{array}$ & $\begin{array}{c}45.7 \% \\
(1,785)\end{array}$ & $\begin{array}{l}30.1 \% \\
(96)\end{array}$ & $\begin{array}{l}40.2 \% \\
(2,232)\end{array}$ \\
\hline No & $\begin{array}{c}49.6 \\
(10,255)\end{array}$ & $\begin{array}{c}68.9 \\
(3,426)\end{array}$ & $\begin{array}{c}54.3 \\
(2,125)\end{array}$ & $\begin{array}{c}69.9 \\
(223)\end{array}$ & $\begin{array}{c}59.8 \\
(3,318)\end{array}$ \\
\hline \multicolumn{6}{|c|}{$\begin{array}{l}\text { Noncash Transaction Method of } \\
\text { Acquisition }\end{array}$} \\
\hline On Credit & $\begin{array}{c}6.9 \\
(1,408)\end{array}$ & $\begin{array}{l}15.5 \\
(748)\end{array}$ & $\begin{array}{c}9.1 \\
(360)\end{array}$ & $\begin{array}{l}16.5 \\
(264)\end{array}$ & $\begin{array}{c}8.4 \\
(464)\end{array}$ \\
\hline Fronted to Sell & $\begin{array}{c}3.3 \\
(682)\end{array}$ & $\begin{array}{c}8.6 \\
(417)\end{array}$ & $\begin{array}{c}5.7 \\
(222)\end{array}$ & $\begin{array}{c}8.5 \\
(136)\end{array}$ & $\begin{array}{c}7.3 \\
(402)\end{array}$ \\
\hline Trade & $\begin{array}{c}4.5 \\
(916)\end{array}$ & $\begin{array}{l}13.0 \\
(624)\end{array}$ & $\begin{array}{c}7.8 \\
(305)\end{array}$ & $\begin{array}{l}13.2 \\
(210)\end{array}$ & $\begin{array}{l}11.0 \\
(605)\end{array}$ \\
\hline Sex & $\begin{array}{c}0.3 \\
(57)\end{array}$ & $\begin{array}{c}0.8 \\
(38)\end{array}$ & $\begin{array}{c}0.7 \\
(28)\end{array}$ & $\begin{array}{l}0.4 \\
(7)\end{array}$ & $\begin{array}{l}0.8 \\
(43)\end{array}$ \\
\hline Gift & $\begin{array}{c}85.0 \\
(17,336)\end{array}$ & $\begin{array}{c}62.1 \\
(2,994)\end{array}$ & $\begin{array}{c}76.6 \\
(3,000)\end{array}$ & $\begin{array}{c}61.3 \\
(978)\end{array}$ & $\begin{array}{c}72.6 \\
(4,003)\end{array}$ \\
\hline Age & $\begin{array}{c}\text { Mean }=28.21 ; \\
\text { S.D. }=9.05\end{array}$ & $\begin{array}{c}\text { Mean }=35.90 ; \\
\text { S.D. }=9.42\end{array}$ & $\begin{aligned} \text { Mean } & =30.96 ; \\
\text { S.D. } & =9.39\end{aligned}$ & $\begin{aligned} \text { Mean } & =35.25 \\
\text { S.D. } & =9.89\end{aligned}$ & $\begin{array}{c}\text { Mean = 31.09; } \\
\text { S.D. } 8.80\end{array}$ \\
\hline Poverty Level & $\begin{array}{c}\text { Mean }=.19 ; \\
\text { S.D. }=.11\end{array}$ & $\begin{array}{c}\text { Mean }=.21 ; \\
\text { S.D. }=.11\end{array}$ & $\begin{array}{c}\text { Mean }=.19 ; \\
\text { S.D. }=.11\end{array}$ & $\begin{array}{c}\text { Mean }=.22 ; \\
\text { S.D. }=.12\end{array}$ & $\begin{array}{c}\text { Mean }=.15 ; \\
\text { S.D. }=.09\end{array}$ \\
\hline Female headed Household & $\begin{array}{c}\text { Mean }=.17 \\
\text { S.D. }=.09\end{array}$ & $\begin{aligned} \text { Mean } & =.18 ; \\
\text { S.D. } & =.10\end{aligned}$ & $\begin{array}{c}\text { Mean }=.16 ; \\
\text { S.D. }=.08\end{array}$ & $\begin{aligned} \text { Mean } & =.19 ; \\
\text { S.D. } & =.10\end{aligned}$ & $\begin{array}{c}\text { Mean }=.13 ; \\
\text { S.D. }=.05\end{array}$ \\
\hline Racial/ethnic Heterogeneity & $\begin{aligned} \text { Mean } & =.45 ; \\
\text { S.D. } & =.18\end{aligned}$ & $\begin{array}{c}\text { Mean }=.46 ; \\
\text { S.D. }=.18\end{array}$ & $\begin{array}{c}\text { Mean }=.45 ; \\
\text { S.D. }=.18\end{array}$ & $\begin{aligned} \text { Mean } & =.44 ; \\
\text { S.D. } & =.19\end{aligned}$ & $\begin{array}{c}\text { Mean }=.48 \\
\text { S.D. }=.17\end{array}$ \\
\hline
\end{tabular}


This document is a research report submitted to the U.S. Department of Justice. This report has not

and do not necessarily reflect the official position or policies of the U.S. Department of Justice.

Table 4. Summary of Significant Gender Effects in Drug Market Indicators - Male and Female Samples Combined

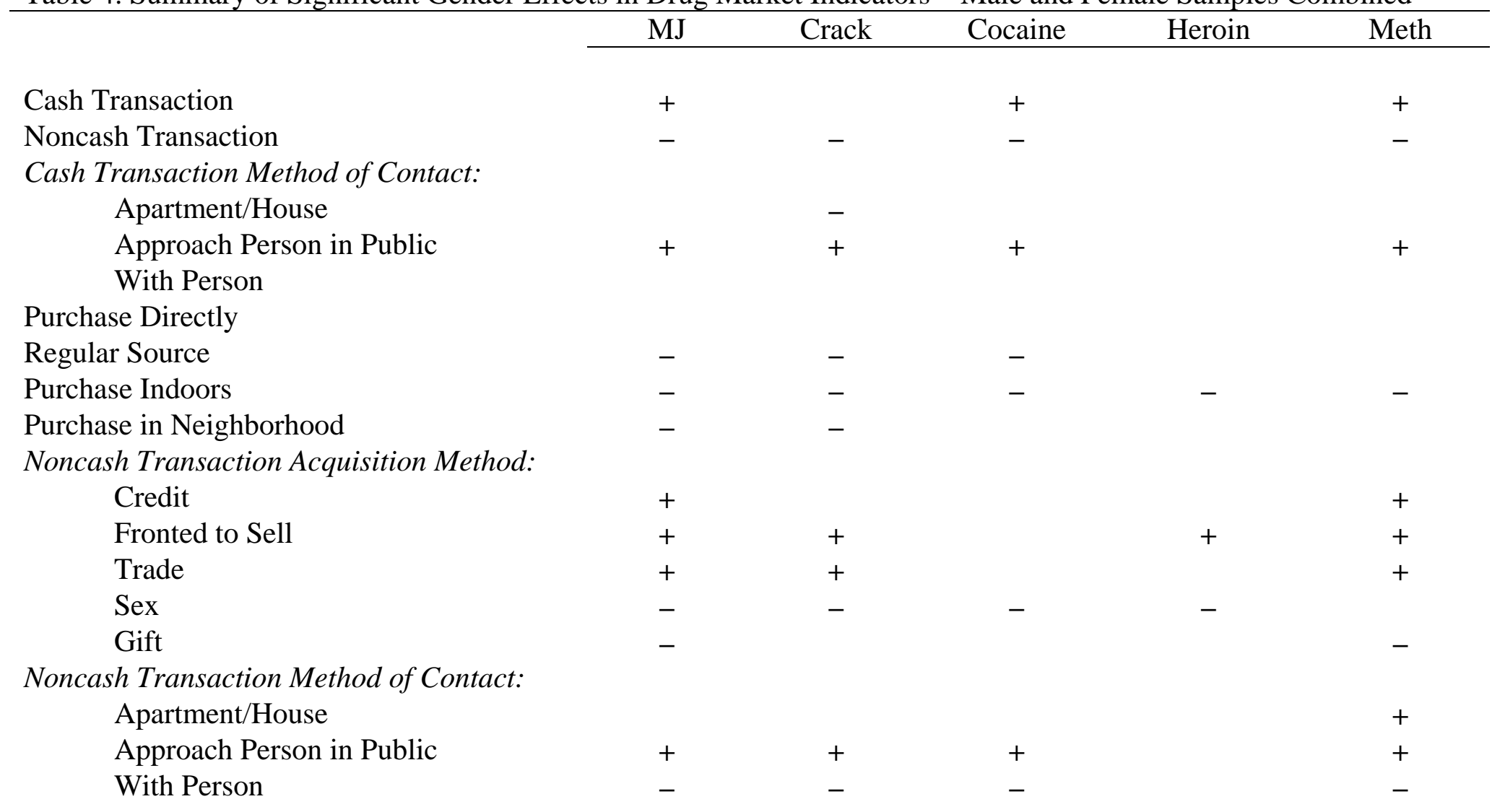

Note: A “+” symbol represents a positive effect; “-” represents a negative effect. Gender is coded as male $=1$, female $=0$. A .05 level of significance was applied. 
This document is a research report submitted to the U.S. Department of Justice. This report has not

and do not necessarily reflect the official position or policies of the U.S. Department of Justice.

Table 5. Summary of Significant Poverty Effects in Drug Market Indicators - Female Sample

\begin{tabular}{lllllll}
\hline & MJ & Crack & Cocaine & Heroin & Meth
\end{tabular}

Cash Transaction

Noncash Transaction

Cash Transaction Method of Contact:

\section{Apartment/House \\ Approach Person in Public \\ With Person}

Purchase Directly

Regular Source

Purchase Indoors

Purchase in Neighborhood

Noncash Transaction Acquisition Method:

Credit

Fronted to Sell

Trade

Sex

Gift

Noncash Transaction Method of Contact:

Apartment/House

Approach Person in Public

With Person

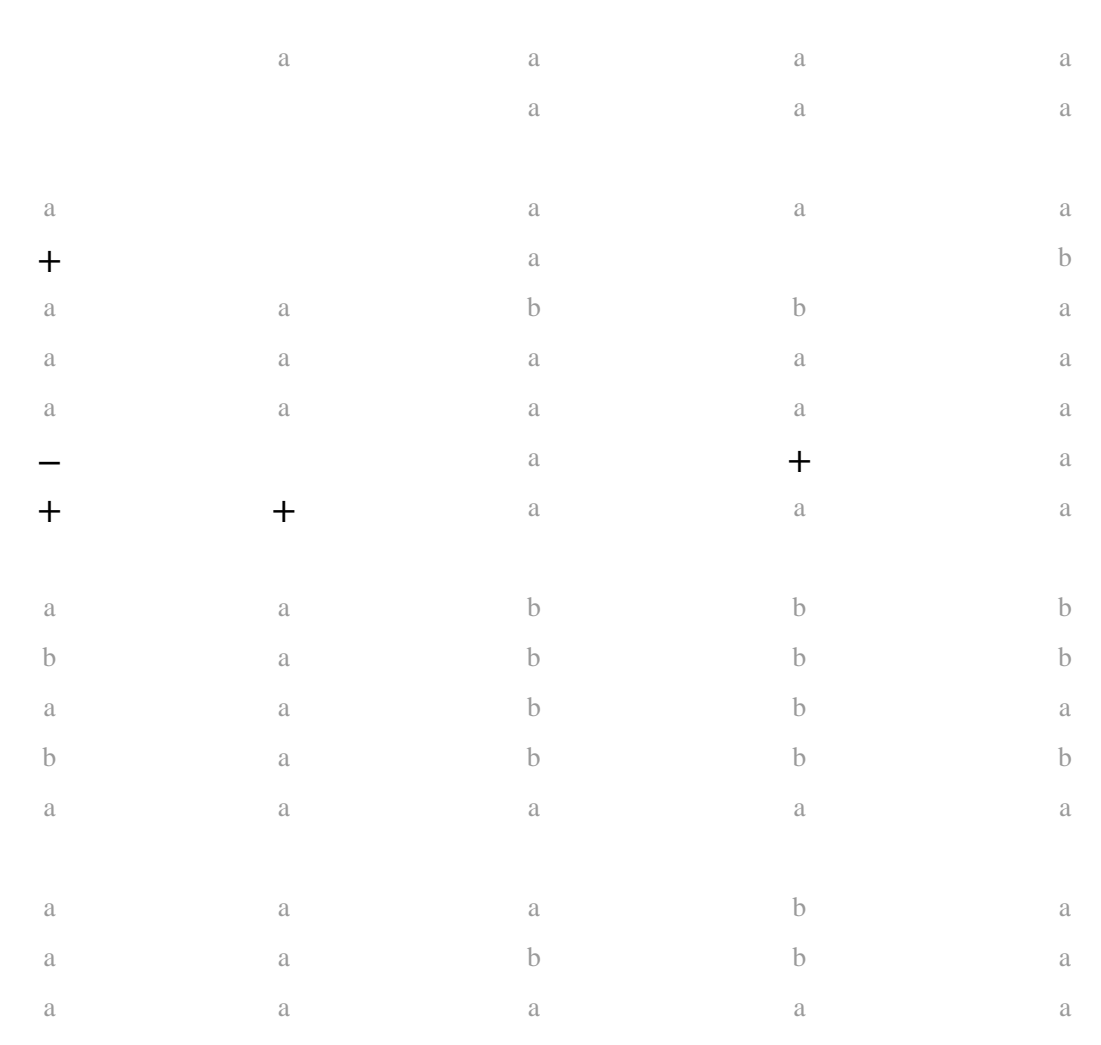

Note: An "a” represents models where the dependent variable did not vary across zip codes. Thus, only Level 1 variables were analyzed in these models. A "b” represents cases where sample size prohibited running a HGLM model. A .05 level of significance was applied. 
This document is a research report submitted to the U.S. Department of Justice. This report has not

and do not necessarily reflect the official position or policies of the U.S. Department of Justice.

Table 6. Summary of Significant Female Headed Household Effects in Drug Market Indicators - Female Sample

\begin{tabular}{|c|c|c|c|c|c|}
\hline 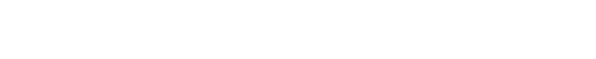 & $\mathrm{MJ}$ & Crack & Cocaine & Heroin & Meth \\
\hline Cash Transaction & + & a & a & a & a \\
\hline Noncash Transaction & - & - & a & a & a \\
\hline \multicolumn{6}{|l|}{ Cash Transaction Method of Contact: } \\
\hline Apartment/House & a & - & a & a & a \\
\hline Approach Person in Public & + & + & a & + & $\mathrm{b}$ \\
\hline With Person & a & a & $\mathrm{b}$ & $\mathrm{b}$ & a \\
\hline Purchase Directly & a & a & a & a & a \\
\hline Regular Source & a & a & a & a & a \\
\hline Purchase Indoors & - & - & a & - & a \\
\hline Purchase in Neighborhood & + & & a & a & a \\
\hline \multicolumn{6}{|c|}{ Noncash Transaction Acquisition Method: } \\
\hline Credit & a & a & $\mathrm{b}$ & $\mathrm{b}$ & $\mathrm{b}$ \\
\hline Fronted to Sell & $\mathrm{b}$ & a & b & $\mathrm{b}$ & $\mathrm{b}$ \\
\hline Trade & a & a & $\mathrm{b}$ & $\mathrm{b}$ & a \\
\hline Sex & $\mathrm{b}$ & a & b & $\mathrm{b}$ & $\mathrm{b}$ \\
\hline Gift & a & a & a & a & a \\
\hline \multicolumn{6}{|c|}{ Noncash Transaction Method of Contact: } \\
\hline Apartment/House & a & $\mathrm{a}$ & a & $\mathrm{b}$ & a \\
\hline Approach Person in Public & a & a & $\mathrm{b}$ & $\mathrm{b}$ & a \\
\hline With Person & a & a & a & a & a \\
\hline
\end{tabular}

Note: An "a” represents models where the dependent variable did not vary across zip codes. Thus, only Level 1 variables were analyzed in these models. A "b” represents cases where sample size prohibited running a HGLM model. A .05 level of significance was applied. 
This document is a research report submitted to the U.S. Department of Justice. This report has not

and do not necessarily reflect the official position or policies of the U.S. Department of Justice.

Table 7. Summary of Significant Female Racial/ethnic Heterogeneity Effects in Drug Market Indicators - Female Sample Cocaine Heroin Meth

Cash Transaction

Noncash Transaction

Cash Transaction Method of Contact:

\section{Apartment/House \\ Approach Person in Public \\ With Person}

Purchase Directly

Regular Source

Purchase Indoors

Purchase in Neighborhood

Noncash Transaction Acquisition Method:

Credit

Fronted to Sell

Trade

Sex

Gift

Noncash Transaction Method of Contact:

Apartment/House

Approach Person in Public

With Person

+
+
a
a
a
а

Note: An "a” represents models where the dependent variable did not vary across zip codes. Thus, only Level 1 variables were analyzed in these models. A "b" represents cases where sample size prohibited running a HGLM model. A .05 level of significance was applied. 
This document is a research report submitted to the U.S. Department of Justice. This report has not

and do not necessarily reflect the official position or policies of the U.S. Department of Justice.

Table 8. Summary of Significant Poverty Effects in Drug Market Indicators - Male Sample

MJ Crack

Cocaine

Heroin

Meth

Cash Transaction

Non-Cash Transaction

Cash Transaction Method of Contact:

\section{Apartment/House \\ Approach Person in Public \\ With Person}

Purchase Directly

Regular Source

Purchase Indoors

Purchase in Neighborhood

Non-Cash Transaction Acquisition Method:

Credit

Fronted to Sell

Trade

Sex

Gift

Non-Cash Transaction Method of Contact:

Apartment/House

Approach Person in Public

With Person

$\begin{array}{lll}+ & & + \\ + & + & + \\ - & \text { a } & \text { a } \\ \text { a } & \text { a } & \text { a } \\ & & \text { a }\end{array}$

$+$

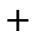

$+$

Note: An "a” represents models where the dependent variable did not vary across zip codes. Thus, only Level 1 variables were analyzed in these models. A "b" represents cases where sample size prohibited running a HGLM model. A .05 level of significance was applied. 
This document is a research report submitted to the U.S. Department of Justice. This report has not

and do not necessarily reflect the official position or policies of the U.S. Department of Justice.

Table 9. Summary of Significant Female Headed Household Effects in Drug Market Indicators - Male Sample

\begin{tabular}{|c|c|c|c|c|c|}
\hline & MJ & Crack & Cocaine & Heroin & Meth \\
\hline Cash Transaction & + & + & & a & a \\
\hline Noncash Transaction & - & - & - & - & \\
\hline \multicolumn{6}{|l|}{ Cash Transaction Method of Contact: } \\
\hline Apartment/House & - & & & a & a \\
\hline Approach Person in Public & + & + & + & + & a \\
\hline With Person & - & a & a & a & a \\
\hline Purchase Directly & a & a & a & a & a \\
\hline Regular Source & & & a & a & a \\
\hline Purchase Indoors & - & - & - & - & \\
\hline Purchase in Neighborhood & + & + & a & & \\
\hline \multicolumn{6}{|c|}{ Noncash Transaction Acquisition Method: } \\
\hline Credit & a & a & a & a & a \\
\hline Fronted to Sell & a & a & a & a & a \\
\hline Trade & $\mathrm{a}$ & a & a & a & a \\
\hline Sex & $\mathrm{b}$ & $\mathrm{b}$ & $\mathrm{b}$ & $\mathrm{b}$ & $\mathrm{b}$ \\
\hline Gift & a & - & a & a & a \\
\hline \multicolumn{6}{|c|}{ Noncash Transaction Method of Contact: } \\
\hline Apartment/House & - & & a & a & \\
\hline Approach Person in Public & + & + & a & + & a \\
\hline With Person & - & a & a & a & a \\
\hline
\end{tabular}

Note: An "a” represents models where the dependent variable did not vary across zip codes. Thus, only Level 1 variables were analyzed in these models. A "b” represents cases where sample size prohibited running a HGLM model. A .05 level of significance was applied. 
This document is a research report submitted to the U.S. Department of Justice. This report has not

and do not necessarily reflect the official position or policies of the U.S. Department of Justice.

Table 10. Summary of Significant Racial/ethnic Heterogeneity Effects in Drug Market Indicators - Male Sample

\begin{tabular}{|c|c|c|c|c|c|}
\hline & MJ & Crack & Cocaine & Heroin & Meth \\
\hline Cash Transaction & - & & - & a & a \\
\hline Noncash Transaction & + & & & & \\
\hline \multicolumn{6}{|l|}{ Cash Transaction Method of Contact: } \\
\hline Apartment/House & - & & - & a & a \\
\hline Approach Person in Public & + & + & & & a \\
\hline With Person & & a & a & a & a \\
\hline Purchase Directly & a & a & a & a & a \\
\hline Regular Source & & & a & a & a \\
\hline Purchase Indoors & - & & - & & - \\
\hline Purchase in Neighborhood & + & & a & + & + \\
\hline \multicolumn{6}{|c|}{ Noncash Transaction Acquisition Method: } \\
\hline Credit & a & a & a & a & a \\
\hline Fronted to Sell & a & a & a & a & a \\
\hline Trade & a & a & a & a & a \\
\hline Sex & $\mathrm{b}$ & b & b & $\mathrm{b}$ & $\mathrm{b}$ \\
\hline Gift & a & & a & a & a \\
\hline \multicolumn{6}{|c|}{ Noncash Transaction Method of Contact: } \\
\hline Apartment/House & & & a & a & \\
\hline Approach Person in Public & + & + & a & & a \\
\hline With Person & - & a & a & a & a \\
\hline
\end{tabular}

Note: An "a” represents models where the dependent variable did not vary across zip codes. Thus, only Level 1 variables were analyzed in these models. A "b” represents cases where sample size prohibited running a HGLM model. A .05 level of significance was applied. 


\section{APPENDIX A. Description of Models}

Leve1 1 and 2 models for the examination of the dependent variables are presented below:

Level 1: (individual)

$$
\begin{gathered}
\eta_{i j}=\beta_{0 j}+\beta_{1 j}\left(X_{1 i j}-X_{1 j}\right)+\ldots+\bar{\beta}_{p j}\left(X_{p i j}-X_{p j}\right)+e_{i j} \\
\text { Level 2: (community) } \\
\beta_{0 j}=\gamma_{00}+\gamma_{01} w_{1 j}+\ldots .+\gamma_{0 q} w_{q j}+u_{0 j}
\end{gathered}
$$

Equation 1 includes variables at the individual level while Equation 2 includes zip code level measures. In Equation 1, $\eta_{i j}$ represents the log-odds of the dependent variables (i.e., log-odds of methamphetamine use) for arrestee $i$ in zip code $j$. In the Level 1 model, $\left(\mathrm{X}_{p i j}-\overline{\mathrm{X}}_{p j}\right)$ refers to the independent variables measured at the individual level. The independent variables are centered around the Level 2 means (group mean centering) given the interest in examining potential differences across zip codes. The $\beta$ coefficients in this model estimates the magnitude of the independent variables' impact on the dependent variable. Subscript $p$ represents the number of individual-level variables (error term $\left(e_{i j}\right)$ represents the variation in error among arrestees). Subscript $q$ represents the number of community-level variables. In Equation $2, \beta_{0 j}$ represents the intercept in Equation 1. This model attempts to predict mean differences in the Level 1 outcome variable across zip codes. In the Level 2 model, $w$ refers to the independent variables measured at the zip code level while the $\gamma$ coefficients represent their effects. Error term in the Level 2 model $\left(u_{p j}\right)$ represents the error across zip codes. 
This document is a research report submitted to the U.S. Department of Justice. This report has not been published by the Department. Opinions or points of view expressed are those of the author(s) and do not necessarily reflect the official position or policies of the U.S. Department of Justice.

APPENDIX B. Models of Combined Samples 


\section{A. Marijuana Models}

Table 1. HLM Regression Estimates of Cash and Noncash Transactions

\begin{tabular}{|c|c|c|}
\hline & Cash $^{b}$ & Noncash $^{c}$ \\
\hline \multicolumn{3}{|l|}{ Fixed Effects } \\
\hline \multirow[t]{2}{*}{ Intercept $^{\mathrm{a}}$} & $.285 * *$ & $1.151 * *$ \\
\hline & $(.081)$ & $(.021)$ \\
\hline \multicolumn{3}{|l|}{ Community-Level Indicators } \\
\hline \multirow[t]{2}{*}{ Poverty Level } & -.317 & .282 \\
\hline & $(.215)$ & $(.254)$ \\
\hline \multirow[t]{2}{*}{ Racial/Ethnic Heterogeneity } & $-.324 * *$ & $.352 * *$ \\
\hline & $(.092)$ & (.108) \\
\hline \multirow[t]{2}{*}{ Female-headed Household } & $2.982 * *$ & $-3.119 * *$ \\
\hline & $(.285)$ & (.330) \\
\hline \multicolumn{3}{|l|}{ Individual-Level Indicators } \\
\hline \multirow[t]{2}{*}{ Gender } & $.598 * *$ & $-.481 * *$ \\
\hline & $(.035)$ & $(.043)$ \\
\hline \multirow[t]{2}{*}{ Age } & $-.021 * *$ & $-.011 * *$ \\
\hline & $(.001)$ & $(.002)$ \\
\hline \multirow[t]{2}{*}{ Black } & $.186 * *$ & $-.190 * *$ \\
\hline & $(.033)$ & $(.037)$ \\
\hline \multirow[t]{2}{*}{ Hispanic/Latino } & $-.196 * *$ & -.015 \\
\hline & $(.043)$ & $(.051)$ \\
\hline \multirow[t]{2}{*}{ Native American } & -.036 & .006 \\
\hline & $(.081)$ & $(.101)$ \\
\hline \multirow[t]{2}{*}{ Violent Offense } & .005 & .036 \\
\hline & $(.028)$ & $(.032)$ \\
\hline \multirow[t]{2}{*}{ Ever Incarcerated } & $.147 * *$ & $.196 * *$ \\
\hline & $(.031)$ & $(.034)$ \\
\hline \multirow[t]{2}{*}{ H.S Education } & $.082 * *$ & $.109 * *$ \\
\hline & $(.026)$ & $(.029)$ \\
\hline \multirow[t]{2}{*}{ Unemployed } & $-.130 * *$ & $.144 * *$ \\
\hline & $(.025)$ & $(.029)$ \\
\hline \multirow[t]{2}{*}{ Married } & .033 & $-.141 * *$ \\
\hline & $(.033)$ & $(.037)$ \\
\hline \multicolumn{3}{|l|}{ Variance Component } \\
\hline Intercept & $.160 * *$ & $.234^{* *}$ \\
\hline
\end{tabular}

${ }^{\mathrm{a}}$ White arrestees represent the reference category.

${ }^{\mathrm{b}}$ Chi-square $=4,128.461 ; \mathrm{df}=2,936$

${ }^{\mathrm{c}}$ Chi-square $=4,220.524 ; \mathrm{df}=2,936$

${ }^{*} \mathrm{p}<.05$; ** $\mathrm{p}<.01$; Standard errors in parentheses. 
Table 2. HLM Regression Estimates of Noncash Acquisition Methods

\section{Fixed Effects}

Intercept $^{\mathrm{a}}$

Community-Level Indicators

Trade $^{d}$

$$
\text { Credit }^{\mathrm{b}} \quad \text { Fronted }^{\mathrm{c}}
$$

$$
-2.723 * *
$$

$-3.555^{* *}$

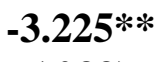

(.047)

(.039)
$1.740 * *$
(.022)

$-6.056 * *$

(.033)

Poverty Level

Racial/Ethnic Heterogeneity

\begin{tabular}{|c|c|c|c|c|c|}
\hline Gender & $\begin{array}{l}.509 * * \\
(.097)\end{array}$ & $\begin{array}{l}.796 * * \\
(.148)\end{array}$ & $\begin{array}{l}.504 * * \\
(.116)\end{array}$ & $\begin{array}{c}-.514 * * \\
(.064)\end{array}$ & $\begin{array}{c}-1.783^{* *} \\
(.271)\end{array}$ \\
\hline \multirow[t]{2}{*}{ Age } & $-.020 * *$ & $-.041 * *$ & $.022 * *$ & $.012 * *$ & .005 \\
\hline & $(.004)$ & $(.006)$ & $(.004)$ & $(.003)$ & $(.014)$ \\
\hline \multirow[t]{2}{*}{ Black } & .100 & $-.534 * *$ & $-.273 * *$ & $.162 * *$ & -.067 \\
\hline & (.083) & $(.121)$ & $(.101)$ & $(.057)$ & $(.344)$ \\
\hline \multirow[t]{2}{*}{ Hispanic/Latino } & -.038 & -.292 & -.231 & $.158 *$ & -.171 \\
\hline & $(.110)$ & (151) & $(.134)$ & (.074) & $(.470)$ \\
\hline \multirow[t]{2}{*}{ Native American } & .279 & -.009 & $-.663^{*}$ & .013 & .951 \\
\hline & $(.191)$ & $(.262)$ & $(.288)$ & $(.134)$ & $(.574)$ \\
\hline \multirow{2}{*}{ Violent Offense } & -.038 & -.003 & $-.451 * *$ & $.178 * *$ & $-.796 *$ \\
\hline & $(.070)$ & $(.100)$ & $(.096)$ & $(.049)$ & $(.375)$ \\
\hline \multirow[t]{2}{*}{ Ever Incarcerated } & $.187^{*}$ & $.474 * *$ & $.454 * *$ & $-.368 * *$ & 1.098* \\
\hline & (.081) & $(.122)$ & (.113) & $(.058)$ & $(.422)$ \\
\hline \multirow[t]{2}{*}{ H.S. Education } & $-.132 *$ & .028 & .147 & -.005 & -.146 \\
\hline & (.064) & $(.092)$ & $(.083)$ & $(.045)$ & $(.267)$ \\
\hline \multirow[t]{2}{*}{ Unemployed } & $-.164 *$ & $.156^{*}$ & $.492 * *$ & $-155^{* *}$ & -.165 \\
\hline & (.064) & (.088) & (.075) & $(.043)$ & $(.261)$ \\
\hline \multirow[t]{2}{*}{ Married } & .098 & -.025 & .162 & -.100 & $-.726 *$ \\
\hline & $(.084)$ & $(.125)$ & $(.098)$ & $(.057)$ & $(.291)$ \\
\hline \multicolumn{6}{|l|}{ riance Component } \\
\hline arcept & .184 & .211 & .072 & .067 & .264 \\
\hline $\begin{array}{l}\text { hite arrestees repre } \\
\text { hi-square }=2,264.8 \\
\text { hi-square }=2,386.7 \\
\text { hi-square }=2,271.5 \\
\text { hi-square }=2,462.8 \\
\text { hi-square }=1,525.10\end{array}$ & $\begin{array}{l}\text { ence cate } \\
2 \\
2 \\
2 \\
2 \\
2\end{array}$ & & & & \\
\hline
\end{tabular}

Female-Headed Household

Individual-Level Indicators 
Table 3. HLM Regression Estimates of Cash Transactions and Method of Contact

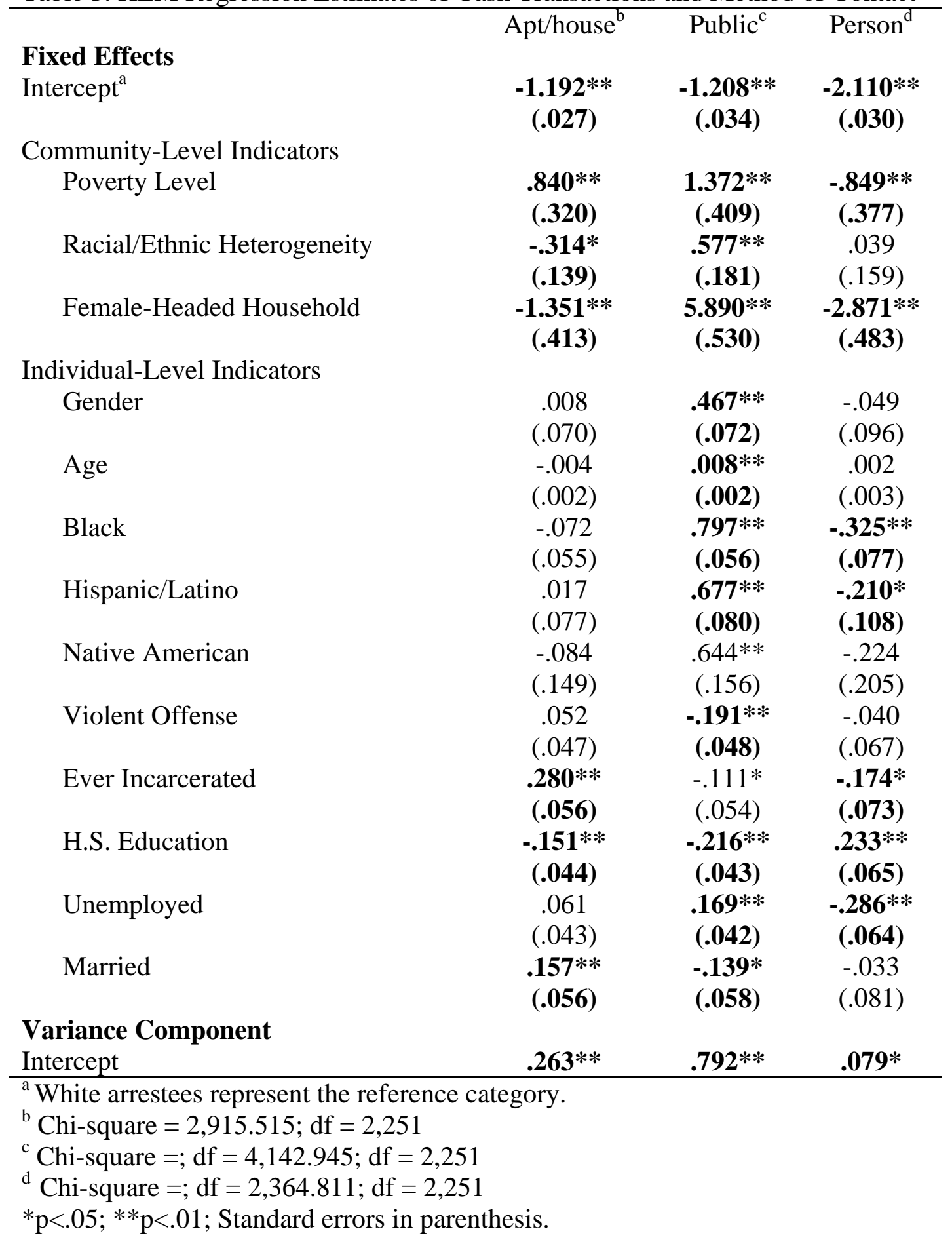


Table 4. HLM Regression Estimates of Noncash Transactions and Method of Contact

\section{Fixed Effects}

Intercept $^{\mathrm{a}}$ Apt/house ${ }^{b} \quad$ Public $^{c} \quad$ Person $^{d}$

Community-Level Indicators

Poverty Level

$\begin{array}{ccc}-1.724 * * & -1.973 * * & .103 * * \\ (.024) & (.031) & (.018)\end{array}$

Racial/Ethnic Heterogeneity

$\begin{array}{ccc}.416 & \mathbf{1 . 8 1 9 * *} & -.207 \\ (.297) & (.326) & (.218) \\ .079 & .522 * * & -.206 * \\ (.131) & (.151) & (.095) \\ -1.369 * * & 3.446 * * & -1.380 * * \\ (.400) & (.432) & \mathbf{( . 2 8 9 )}\end{array}$

Individual-Level Indicators

Female-Headed Household

Gender

(.060)

Age

$-.282 * *$

(.002)

Black

Hispanic/Latino

Native American

$-.053$

(.002)

$.658 * *$

(.002)

Native American

(.135)

Violent Offense

Ever Incarcerated

Ever Incarcerated

$.305 * *$

(.076)

H.S. Education

(.057)

.259

(.053)

Unemployed

$-.044$

(.144)

$-.026$

Unemployed

$(.045)$

$-.185^{* *}$

(.050)

(.035)

$.156 * * \quad-.368 * *$

Married

\section{Variance Component}

${ }^{\mathrm{a}}$ White arrestees represent the reference category.

${ }^{\mathrm{b}}$ Chi-square $=2,733.598 ; \mathrm{df}=2,459$

${ }^{\mathrm{c}}$ Chi-square $=2,987.457 ; \mathrm{df}=2,459$

${ }^{\mathrm{d}}$ Chi-square $=2,831.064 ; \mathrm{df}=2,459$

${ }^{*} \mathrm{p}<.05 ;{ }^{*} \mathrm{p}<.01$; Standard errors in parenthesis. 
Table 5. HLM Regression Estimates of Cash Transactions: Purchase Directly and Source

\section{Fixed Effects}

Intercept $^{\mathrm{a}}$

Community-Level Indicators

Poverty Level

Racial/Ethnic Heterogeneity

Female-Headed Household

$$
\text { Direct }^{\text {b }} \quad \text { Regular }^{\mathrm{C}}
$$

$\begin{array}{cc}\text { 3.038** } & -.037 \\ \mathbf{( . 0 3 9 )} & (.020)\end{array}$

ndividual-Level Indicators

Gender

.224

(.128)

Age

$-.013 * *$

(.005)

Black

.140

(.110)

Hispanic/Latino

.004

(.153)

Native American

$-.273$

(.264)

Violent Offense

.053

(.095)

Ever Incarcerated

.201*

(.102)

H.S. Education

.198*

(.086)

Unemployed

.092

(.086)

$-.097$

(.109)

.148

(.226)

$-.048$

(.098)

.093

(.286)

Married

Variance Component

.089
$-.370 * *$

(.058)

$-.001$

(.002)

$-.175 * *$

(.046)

$-.200 * *$

(.065)

$-.310 *$

(.125)

.084*

(.039)

$.236 * *$

(.045)

$-.071$

(.037)

$-.007$

(.036)

.105*

(.048)
Intercept

$.044 *$

${ }^{\mathrm{a}}$ White arrestees represent the reference category.

${ }^{\mathrm{b}}$ Chi-square $=2,238.121 ; \mathrm{df}=2,254$

${ }^{\mathrm{c}}$ Chi-square $=2,389.517 ; \mathrm{df}=2,251$

${ }^{*} \mathrm{p}<.05 ;{ }^{* *} \mathrm{p}<.01$; Standard errors in parenthesis. 
Table 6. HLM Regression Estimates of Cash Transaction Location Purchase

\begin{tabular}{|c|c|c|}
\hline & House $^{b}$ & $\operatorname{Hood}^{\mathrm{C}}$ \\
\hline \multicolumn{3}{|l|}{ Fixed Effects } \\
\hline \multirow[t]{2}{*}{ Intercept $^{\mathrm{a}}$} & $.324 * *$ & $-.443 * *$ \\
\hline & $(.029)$ & $(.022)$ \\
\hline \multicolumn{3}{|l|}{ Community-Level Indicators } \\
\hline \multirow[t]{2}{*}{ Poverty Level } & $-1.004 * *$ & $1.969 * *$ \\
\hline & $(.353)$ & $(.260)$ \\
\hline \multirow[t]{2}{*}{ Racial/Ethnic Heterogeneity } & $-.553 * *$ & $.360 * *$ \\
\hline & $(.152)$ & $(.114)$ \\
\hline \multirow[t]{2}{*}{ Female-Headed Household } & $-4.413 * *$ & $1.195 * *$ \\
\hline & $(.460)$ & (.331) \\
\hline \multicolumn{3}{|l|}{ Individual-Level Indicators } \\
\hline \multirow[t]{2}{*}{ Gender } & $-.415 * *$ & $-.212 * *$ \\
\hline & $(.063)$ & $(.059)$ \\
\hline \multirow[t]{2}{*}{ Age } & -.000 & $.007 * *$ \\
\hline & $(.002)$ & $(.002)$ \\
\hline \multirow[t]{2}{*}{ Black } & $-.659 * *$ & $.007 * *$ \\
\hline & $(.049)$ & $(.002)$ \\
\hline \multirow[t]{2}{*}{ Hispanic/Latino } & $-.365 * *$ & -.121 \\
\hline & $(.070)$ & $(.067)$ \\
\hline \multirow[t]{2}{*}{ Native American } & $-.498 * *$ & $-.354 * *$ \\
\hline & (.130) & $(.132)$ \\
\hline \multirow[t]{2}{*}{ Violent Offense } & $.149 * *$ & -.002 \\
\hline & $(.043)$ & $(.041)$ \\
\hline \multirow[t]{2}{*}{ Ever Incarcerated } & $.104 *$ & $.346 * *$ \\
\hline & (.049) & $(.046)$ \\
\hline \multirow[t]{2}{*}{ H.S. Education } & $.161 * *$ & -.058 \\
\hline & $(.040)$ & $(.038)$ \\
\hline \multirow[t]{2}{*}{ Unemployed } & -.041 & $.176 * *$ \\
\hline & $(.039)$ & $(.037)$ \\
\hline \multirow[t]{2}{*}{ Married } & $.103^{*}$ & $-.125 *$ \\
\hline & $(.052)$ & (.049) \\
\hline \multicolumn{3}{|l|}{ Variance Component } \\
\hline Intercept & $.551 * *$ & $.129 * *$ \\
\hline \multicolumn{3}{|c|}{${ }^{\mathrm{a}}$ White arrestees represent the reference category, } \\
\hline \multicolumn{3}{|c|}{${ }^{\mathrm{b}}$ Chi-square $=4017.831 ; \mathrm{df}=2251$} \\
\hline \multicolumn{3}{|l|}{${ }^{\mathrm{c}}$ Chi-square $=2756.301 ; \mathrm{df}=2251$} \\
\hline$* \mathrm{p}<.05 ; * * \mathrm{p}<.01 ;$ Standard errors in & & \\
\hline
\end{tabular}


B. Crack Models

Table 1. HLM Regression Estimates of Cash and Noncash Transactions

\begin{tabular}{|c|c|c|}
\hline & Cash $^{b}$ & Noncash $^{\mathrm{c}}$ \\
\hline \multicolumn{3}{|l|}{ Fixed Effects } \\
\hline Intercept $^{\mathrm{a}}$ & $\begin{array}{c}1.406 * * \\
(.029)\end{array}$ & $\begin{array}{l}.340 * * \\
(.026)\end{array}$ \\
\hline \multicolumn{3}{|l|}{ Community-Level Indicators } \\
\hline Poverty Level & $\begin{array}{c}.587 \\
(.312)\end{array}$ & $\begin{array}{c}-.318 \\
(.275)\end{array}$ \\
\hline Racial/Ethnic Heterogeneity & $\begin{array}{c}-.090 \\
(.152)\end{array}$ & $\begin{array}{c}.020 \\
(.134)\end{array}$ \\
\hline Female-Headed Household & $\begin{array}{c}1.368^{* * *} \\
(.399)\end{array}$ & $\begin{array}{c}-1.704^{* *} \\
(.353)\end{array}$ \\
\hline \multicolumn{3}{|l|}{ Individual-Level Indicators } \\
\hline Gender & $\begin{array}{l}-.064 \\
(.061)\end{array}$ & $\begin{array}{c}-.226 * * \\
(.048)\end{array}$ \\
\hline Age & $\begin{array}{l}.028 * * \\
(.003)\end{array}$ & $\begin{array}{c}-.009 * * \\
(.002)\end{array}$ \\
\hline Black & $\begin{array}{c}.026 \\
(.066)\end{array}$ & $\begin{array}{l}.113^{*} \\
(.052)\end{array}$ \\
\hline Hispanic/Latino & $\begin{array}{c}-.294^{* *} \\
(.101)\end{array}$ & $\begin{array}{l}.110 \\
(.085)\end{array}$ \\
\hline Native American & $\begin{array}{c}-.650^{* * *} \\
(.163)\end{array}$ & $\begin{array}{c}.215 \\
(.155)\end{array}$ \\
\hline Violent Offense & $\begin{array}{c}-.297 * * \\
(.065)\end{array}$ & $\begin{array}{l}-.035 \\
(.054)\end{array}$ \\
\hline Ever Incarcerated & $\begin{array}{l}.458 * * \\
(.078)\end{array}$ & $\begin{array}{l}.124 \\
(.066)\end{array}$ \\
\hline H.S. Education & $\begin{array}{l}.122^{*} \\
(.054)\end{array}$ & $\begin{array}{l}.223 * * \\
(.043)\end{array}$ \\
\hline Unemployed & $\begin{array}{l}.067 \\
(.051)\end{array}$ & $\begin{array}{l}.169 * * \\
(.040)\end{array}$ \\
\hline Married & $\begin{array}{l}.004 \\
(.064)\end{array}$ & $\begin{array}{c}.005 \\
(.051)\end{array}$ \\
\hline Variance Component & & \\
\hline
\end{tabular}

\footnotetext{
${ }^{a}$ White arrestees represent the reference category.

${ }^{\mathrm{b}}$ Chi-square $=2,017.401 ; \mathrm{df}=1,876$

${ }^{\mathrm{c}}$ Chi-square $=2,354.156 ; \mathrm{df}=1,876$

${ }^{*} \mathrm{p}<.05 ;{ }^{* *} \mathrm{p}<.01$; Standard errors in parenthesis.
} 
Table 2. HLM Regression Estimates of Noncash Acquisition Methods

\begin{tabular}{|c|c|c|c|c|c|}
\hline 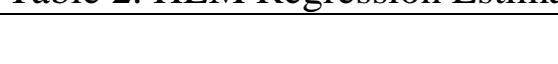 & Credit $^{b}$ & Fronted $^{\mathrm{c}}$ & Trade $^{\mathrm{d}}$ & $\mathrm{Gift}^{\mathrm{e}}$ & Sex $^{f}$ \\
\hline \multicolumn{6}{|l|}{ Fixed Effects } \\
\hline Intercept $^{\mathrm{a}}$ & $\begin{array}{c}-1.715^{* *} \\
(.039)\end{array}$ & $\begin{array}{c}-2.690 * * \\
(.058)\end{array}$ & $\begin{array}{c}-1.987 * * \\
(.048)\end{array}$ & $\begin{array}{l}.390 * * \\
(.034)\end{array}$ & $\begin{array}{c}-3.900 * * \\
(.109)\end{array}$ \\
\hline \multicolumn{6}{|l|}{ Community-Level Indicators } \\
\hline Poverty Level & & & $\begin{array}{c}-1.174 * \\
(.541)\end{array}$ & $\begin{array}{c}.613 \\
(.362)\end{array}$ & \\
\hline Racial/Ethnic Heterogeneity & & & $\begin{array}{l}-.112 \\
(.256)\end{array}$ & $\begin{array}{c}.330 \\
(.176)\end{array}$ & \\
\hline Female-Headed Household & & & $\begin{array}{l}-.607 \\
(.687)\end{array}$ & $\begin{array}{c}-1.008 * \\
(.466)\end{array}$ & \\
\hline \multicolumn{6}{|l|}{ Individual-Level Indicators } \\
\hline Gender & $\begin{array}{l}-.102 \\
(.096)\end{array}$ & $\begin{array}{c}.676 * * \\
(.144)\end{array}$ & $\begin{array}{c}.565^{* *} \\
(.117)\end{array}$ & $\begin{array}{l}-.033 \\
(.071)\end{array}$ & $\begin{array}{c}-2.582 * * \\
(.199)\end{array}$ \\
\hline Age & $\begin{array}{c}.008 \\
(.005)\end{array}$ & $\begin{array}{c}-.073 * * \\
(.007)\end{array}$ & $\begin{array}{l}-.001 \\
(.006)\end{array}$ & $\begin{array}{l}.024 * * \\
(.004)\end{array}$ & $\begin{array}{c}-.031 * * \\
(.010)\end{array}$ \\
\hline Black & $\begin{array}{l}.050 \\
(.110)\end{array}$ & $\begin{array}{l}.487 * * \\
(.154)\end{array}$ & $\begin{array}{c}-.397 * * \\
(.120)\end{array}$ & $\begin{array}{c}.057 \\
(.081)\end{array}$ & $\begin{array}{l}-.196 \\
(.202)\end{array}$ \\
\hline Hispanic/Latino & $\begin{array}{l}.315 \\
(.179)\end{array}$ & $\begin{array}{l}-.396 \\
(.259)\end{array}$ & $\begin{array}{l}-.479 * \\
(.203)\end{array}$ & $\begin{array}{l}.269 * \\
(.134)\end{array}$ & $\begin{array}{l}-.562 \\
(.366)\end{array}$ \\
\hline Native American & $\begin{array}{l}-.306 \\
(.315)\end{array}$ & $\begin{array}{l}.338 \\
(.365)\end{array}$ & $\begin{array}{l}-.797^{*} \\
(.372)\end{array}$ & $\begin{array}{l}.557^{*} \\
(.221)\end{array}$ & $\begin{array}{c}1.401 * \\
(.680)\end{array}$ \\
\hline Violent Offense & $\begin{array}{l}-.126 \\
(.118)\end{array}$ & $\begin{array}{l}-.058 \\
(.157)\end{array}$ & $\begin{array}{l}-.320 * \\
(.138)\end{array}$ & $\begin{array}{l}.294 * * \\
(.087)\end{array}$ & $\begin{array}{l}-.288 \\
(.263)\end{array}$ \\
\hline Ever Incarcerated & $\begin{array}{l}.268 \\
(.156)\end{array}$ & $\begin{array}{l}-.160 \\
(.195)\end{array}$ & $\begin{array}{l}.194 \\
(.182)\end{array}$ & $\begin{array}{l}-.168 \\
(.111)\end{array}$ & $\begin{array}{l}.390 \\
(.285)\end{array}$ \\
\hline H.S. Education & $\begin{array}{l}-.020 \\
(.092)\end{array}$ & $\begin{array}{l}.034 \\
(.127)\end{array}$ & $\begin{array}{l}.240 * \\
(.110)\end{array}$ & $\begin{array}{l}-.092 \\
(.069)\end{array}$ & $\begin{array}{l}.107 \\
(.175)\end{array}$ \\
\hline Unemployed & $\begin{array}{c}.003 \\
(.083)\end{array}$ & $\begin{array}{l}-.066 \\
(.115)\end{array}$ & $\begin{array}{l}.133 \\
(.095)\end{array}$ & $\begin{array}{l}-.077 \\
(.062)\end{array}$ & $\begin{array}{l}.331 * \\
(.160)\end{array}$ \\
\hline Married & $\begin{array}{l}.092 \\
(.105)\end{array}$ & $\begin{array}{c}.069 \\
(.152)\end{array}$ & $\begin{array}{l}.106 \\
(.121)\end{array}$ & $\begin{array}{l}-.051 \\
(.080)\end{array}$ & $\begin{array}{c}.091 \\
(.210)\end{array}$ \\
\hline Variance Component & & & & & \\
\hline Intercept & .116 & .071 & .137 & $.108 * *$ & .493 \\
\hline
\end{tabular}

${ }^{\mathrm{a}}$ White arrestees represent the reference category.

${ }^{\mathrm{b}}$ Chi-square $=1,353.721 ; \mathrm{df}=1,300$

${ }^{\mathrm{c}}$ Chi-square $=1,197.197 ; \mathrm{df}=1,300$

${ }^{\mathrm{d}}$ Chi-square $=1,338.057 ; \mathrm{df}=1,297$

${ }^{\mathrm{e}}$ Chi-square $=1,443.396 ; \mathrm{df}=1,297$

${ }^{\mathrm{f}}$ Chi-square $=1,345.895 ; \mathrm{df}=1,300$

${ }^{*} \mathrm{p}<.05 ;{ }^{* *} \mathrm{p}<.01$; Standard errors in parenthesis. 
Table 3. HLM Regression Estimates of Cash Transactions and Method of Contact

\section{Fixed Effects}

Intercept $^{\mathrm{a}}$

$\begin{array}{ccc}\text { Apt}_{\text {house }}{ }^{\mathrm{b}} & \text { Public }^{\mathrm{c}} & \text { Person }^{\mathrm{d}} \\ \mathbf{- 1 . 2 2 6 * *}^{*} & -\mathbf{6 0 6 * *} & \mathbf{- . 1 5 4 * *} \\ \mathbf{( . 0 4 0 )} & \mathbf{( . 0 4 0 )} & \mathbf{( . 0 5 6 )}\end{array}$

Community-Level Indicators

Poverty Level

$\begin{array}{cc}.515 & 1.039 * \\ (.434) & (.439) \\ -.012 & .443^{*} \\ (.211) & (.212) \\ -1.156 * & 3.936^{* *} \\ \mathbf{( . 5 6 0 )} & \mathbf{( . 5 6 4 )}\end{array}$

Individual-Level Indicators

Gender

Age

(.065)

Black

$.016 * *$

$-.006$

$-.029$

(.003)

(.007)

Hispanic/Latino

(.076)

$.555^{* *}$

$-.143$

.107

(.069)

(.153)

Native American

(.123)

$.345 * *$

$-.167$

$-.238$

(.121)

(.261)

Violent Offense

(.273)

.664**

.410

.072

(.238)

(.442)

Ever Incarcerated

(.081)

$-.152 *$

$-.113$

Ever Incarcerated

.189

(.074)

(.173)

(.106)

$-.277 * *$

$-.342$

H.S. Education

.063

(.091)

(.188)

Unemployed

(.064)

$-.202 * *$

$-.007$

(.056)

(.129)

(.059)

.086

$-.192$

Married

$.205^{* *}$

(.052)

(.120)

(.072)

(.067)

Variance Component

$.543^{* *}$

.158

\footnotetext{
${ }^{\mathrm{a}}$ White arrestees represent the reference category.

${ }^{\mathrm{b}}$ Chi-square $=2,290.347 ; \mathrm{df}=1,616$

${ }^{\mathrm{c}}$ Chi-square $=2,775.205 ; \mathrm{df}=1,616$

${ }^{\mathrm{d}}$ Chi-square $=1,385.486 ; \mathrm{df}=1,619$

${ }^{*} \mathrm{p}<.05 ;{ }^{* *} \mathrm{p}<.01$; Standard errors in parenthesis.
} 
Table 4. HLM Regression Estimates of Noncash Transactions and Method of Contact

Fixed Effects

Intercept $^{\mathrm{a}}$ Apt/house ${ }^{b}$ Public $^{\mathrm{b}}$ Person $^{\mathrm{d}}$

$\begin{array}{ccc}-1.472 * * & -1.383 * * & -.728 * * \\ (.042) & (.045) & (.030)\end{array}$

Community-Level Indicators

Poverty Level

$-.228$

$1.280 * *$

Racial/Ethnic Heterogeneity

$(.466)$

(.445)

$-.349$

.611**

Female-Headed Household

(.225)

(.226)

$-.474$

3.042**

Individual-Level Indicators

(.600)

(.580)

Gender

.013

(.092)

Age

.003

Black

(.005)

.067

(.103)

Hispanic/Latino

$.432 * *$

(.162)

.126

(.268)

Violent Offense

(.105)

Ever Incarcerated

H.S. Education

.113

(.088)

$.477^{* *}$

(.085)

$-.265 * *$

$-.007$

(.074)

(.004)

$.013^{* *}$

$.644 * *$

(.004)

(.097)

$-.283 * *$

.131

(.084)

(.164)

$-.117$

.248

(.139)

(.261)

.261

$-.261 *$

(.212)

(.101)

.215*

$-.063$

(.087)

(.126)

$-.196$

-.192*

(.112)

(.077)

.091

Unemployed

$.180 *$

(.072)

Married

(.071)

$-.204 * *$

.122

$-.248 *$

(.065)

(.099)

(.095)

.024

(.082)

\section{Variance Component}

.198

$.261 * *$

.061

\footnotetext{
${ }^{\mathrm{a}}$ White arrestees represent the reference category.

${ }^{\mathrm{b}}$ Chi-square $=1,380.738 ; \mathrm{df}=1,297$

${ }^{\mathrm{c}}$ Chi-square $=1,498.107 ; \mathrm{df}=1,297$

${ }^{\mathrm{d}}$ Chi-square $=1,341.703 ; \mathrm{df}=1,300$

${ }^{*} \mathrm{p}<.05 ;{ }^{* *} \mathrm{p}<.01$; Standard errors in parenthesis.
} 
Table 5. HLM Regression Estimates of Cash Transactions: Purchase Directly and Source

\section{Fixed Effects}

Intercept $^{\mathrm{a}}$

$$
\text { Direct }^{\mathrm{b}} \quad \text { Regular }^{\mathrm{C}}
$$

$\begin{array}{cc}2.717 * * & .201 * * \\ (.049) & (.028)\end{array}$

Community-Level Indicators

Poverty Level

Racial/Ethnic Heterogeneity

Female-Headed Household

Individual-Level Indicators

Gender

Age

Black

Hispanic/Latino

Native American

Violent Offense

Ever Incarcerated

H.S. Education

Unemployed

Married

\section{Variance Component}

.012

(.120)

$-.003$

(.006)

(.126)

$-.016$

(.209)

$-.360$

(.375)

$-.141$

(.133)

.284

$(.161)$

$-.016$

(.106)

$-.022$

(.124)
$-.489 * *$

(.059)

$-.011 * *$

(.003)

-.196**

(.063)

$-.284 * *$

(.106)

$-.445 *$

(.214)

$-.019$

(.068)

$.239 * *$

(.084)

.012

(.052)

.116*

(.048)

$-.008$

$(.061)$

Intercept

.277

.074*

\footnotetext{
${ }^{\mathrm{a}}$ White arrestees represent the reference category.

${ }^{\mathrm{b}}$ Chi-square $=1,614.880 ; \mathrm{df}=1,619$

${ }^{\mathrm{c}}$ Chi-square $=1,745.209 ; \mathrm{df}=1,616$

${ }^{*} \mathrm{p}<.05 ;{ }^{* *} \mathrm{p}<.01$; Standard errors in parenthesis.
} 
Table 6. HLM Regression Estimates of Cash Transaction Location Purchase

\begin{tabular}{|c|c|c|}
\hline \multirow{2}{*}{\multicolumn{3}{|c|}{ Fixed Effects }} \\
\hline & & \\
\hline Intercept $^{\mathrm{a}}$ & $\begin{array}{c}-.151 * * \\
(.036)\end{array}$ & $\begin{array}{c}-.305 * * \\
(.030)\end{array}$ \\
\hline \multicolumn{3}{|l|}{ Community-Level Indicators } \\
\hline Poverty Level & $\begin{array}{l}-.286 \\
(.401)\end{array}$ & $\begin{array}{c}2.187^{* *} \\
(.312)\end{array}$ \\
\hline Racial/Ethnic Heterogeneity & $\begin{array}{l}-.293 \\
(.192)\end{array}$ & $\begin{array}{c}.272 \\
(.154)\end{array}$ \\
\hline Female-Headed Household & $\begin{array}{c}-2.844^{* *} \\
(.517)\end{array}$ & $\begin{array}{c}1.773 * * \\
(.393)\end{array}$ \\
\hline \multicolumn{3}{|l|}{ Individual-Level Indicators } \\
\hline Gender & $\begin{array}{c}-.274 * * \\
(.062)\end{array}$ & $\begin{array}{c}-.225^{* *} \\
(.059)\end{array}$ \\
\hline Age & $\begin{array}{c}-.009 * * \\
(.003)\end{array}$ & $\begin{array}{l}.006 * \\
(.003)\end{array}$ \\
\hline Black & $\begin{array}{c}-.278 * * \\
(.065)\end{array}$ & $\begin{array}{c}.050 \\
(.063)\end{array}$ \\
\hline Hispanic/Latino & $\begin{array}{l}-.136 \\
(.110)\end{array}$ & $\begin{array}{l}.062 \\
(.107)\end{array}$ \\
\hline Native American & $\begin{array}{l}-.441 * \\
(.220)\end{array}$ & $\begin{array}{l}.085 \\
(.217)\end{array}$ \\
\hline Violent Offense & $\begin{array}{l}.218 * * \\
(.070)\end{array}$ & $\begin{array}{l}.154 * \\
(.069)\end{array}$ \\
\hline Ever Incarcerated & $\begin{array}{c}.145 \\
(.090)\end{array}$ & $\begin{array}{l}.276 * * \\
(.003)\end{array}$ \\
\hline H.S. Education & $\begin{array}{l}.162 * * \\
(.055)\end{array}$ & $\begin{array}{l}-.034 \\
(.053)\end{array}$ \\
\hline Unemployed & $\begin{array}{c}-.134 * * \\
(.051)\end{array}$ & $\begin{array}{l}.189 * * \\
(.049)\end{array}$ \\
\hline Married & $\begin{array}{l}.157^{*} \\
(.064)\end{array}$ & $\begin{array}{l}-.136 * \\
(.062)\end{array}$ \\
\hline Variance Component & & \\
\hline Intercept & $.538 * *$ & $.143 * *$ \\
\hline
\end{tabular}




\section{Cocaine Models}

Table 1. HLM Regression Estimates of Cash and Noncash Transactions

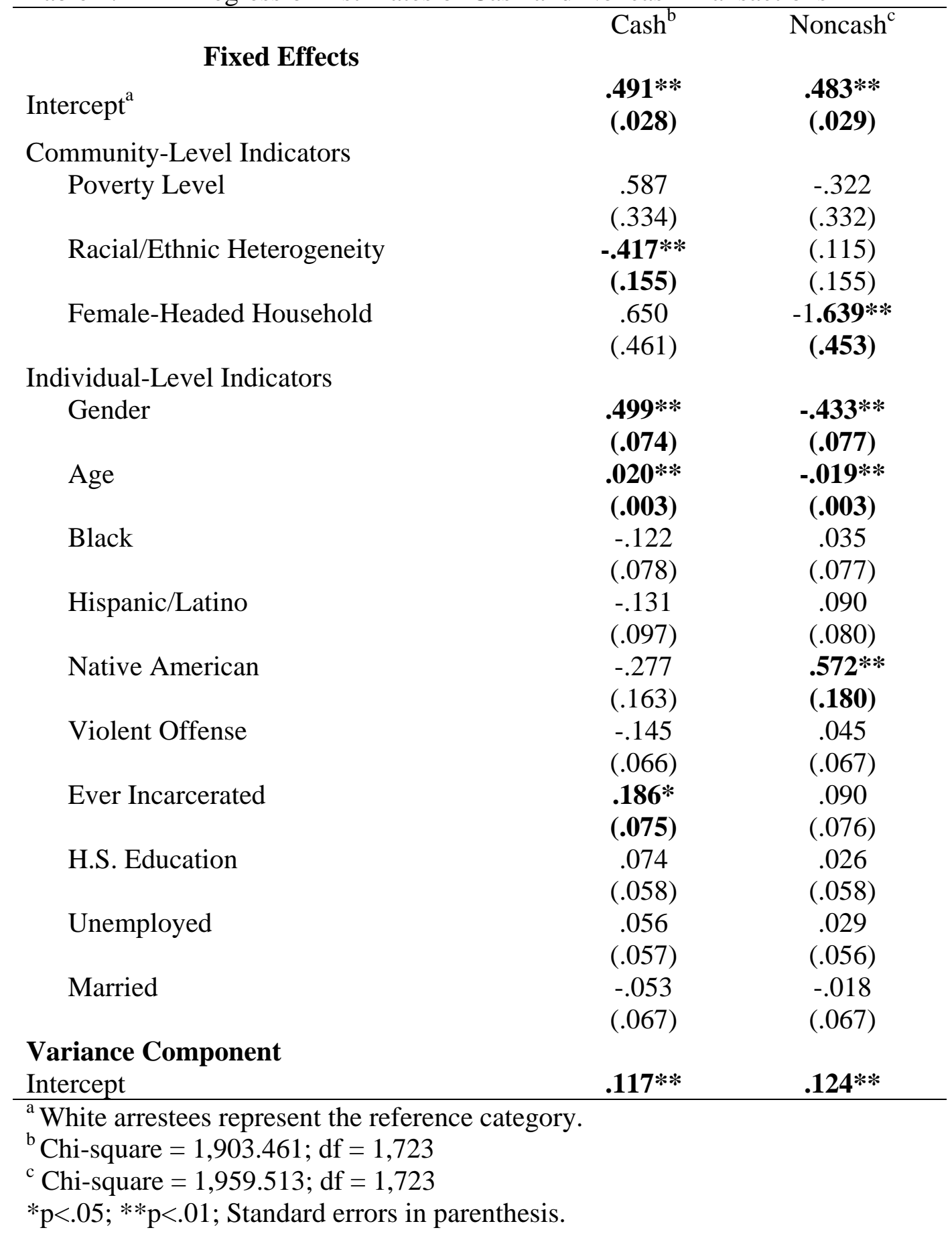


Table 2. HLM Regression Estimates of Noncash Acquisition Methods

Credit $^{\mathrm{b}} \quad$ Fronted $^{\mathrm{c}} \quad$ Trade $^{\mathrm{d}} \quad$ Gift $^{\mathrm{e}} \quad$ Sex $^{\mathrm{f}}$

Fixed Effects

Intercept $^{\mathrm{a}}$

$\begin{array}{ccccc}-2.386 * * & -2.971 * * & -2.583 * * & 1.128 * * & -4.623 * * \\ (.057) & (.078) & (.065) & (.038) & (.170)\end{array}$

Community-Level Indicators

Poverty Level

Racial/Ethnic Heterogeneity

Female-Headed Household

Individual-Level Indicators

Gender

$$
\begin{gathered}
.196 \\
(.190) \\
.008
\end{gathered}
$$

.464

Age

(.252)

$(.008)$

$-.044 * *$

.247

$(.205)$

$.026 * *$

$-.159$

$-2.177^{* *}$

Black

.467*

(.010)

(.008)

(.122)

(.342)

Black

(.197)

$.630 * *$

$-.107$

$-.002$

.024

Hispanic/Latin

.228

(.239)

(.211)

(.005)

(.018)

-

(.198)

$-.209$

$-.255$

$-.269 *$

$-.478$

Native American

.726*

(.253)

(.211)

(.130)

(.481)

Violent Offense

(.329)

$-.365$

$-.601$

.146

$-.663$

(.129)

(.455)

$-.303$

(.519)

(.446)

.181

$-1.096$

Ever Incarcerated

(.173)

.050

$-.093$

(.249)

(.974)

.526*

(.209)

(.183)

.204

.304

H.S. Education

(.218)

.559**

$-910 * *$

(.112)

(.397)

$-.199$

(.274)

(.259)

$-.736 * *$

.941

.120

.121

(.143)

(.548)

Unemployed

(.144)

(.186)

(.159)

$-.005$

.011

$-.174$

.155

(.096)

(.341)

Married

(.143)

(.176)

$.347^{*}$

$-.137$

.195

.030

$-.211$

(.148)

(.092)

(.324)

(.170)

(.230)

$-.012$

.081

(.183)

(.114)

$-.205$

(.409)

\section{Variance Component}

.037

.316

.138

.039

${ }^{\mathrm{a}}$ White arrestees represent the reference category.

${ }^{\mathrm{b}}$ Chi-square $=1,164.675 ; \mathrm{df}=1,276$

${ }^{\mathrm{c}}$ Chi-square $=1,178.721 ; \mathrm{df}=1,276$

${ }^{\mathrm{d}}$ Chi-square $=1,306.558 ; \mathrm{df}=1,276$

${ }^{\text {e }}$ Chi-square $=1,314.628 ; \mathrm{df}=1,276$

${ }^{\mathrm{f}}$ Chi-square $=, 1274.803 ; \mathrm{df}=1,276$

${ }^{*} \mathrm{p}<.05 ;{ }^{*} \mathrm{p}<.01$; Standard errors in parenthesis. 
Table 3. HLM Regression Estimates of Cash Transactions and Method of Contact

\begin{tabular}{|c|c|c|c|}
\hline & Apt/house $^{b}$ & Public $^{\mathrm{c}}$ & Person $^{\mathrm{d}}$ \\
\hline \multicolumn{4}{|l|}{ Fixed Effects } \\
\hline Intercept $^{\mathrm{a}}$ & $\begin{array}{c}-1.481 * * \\
(.049)\end{array}$ & $\begin{array}{c}-1.421^{* *} \\
(.056)\end{array}$ & $\begin{array}{c}-2.562 * * \\
(.063)\end{array}$ \\
\hline \multicolumn{4}{|l|}{ Community-Level Indicators } \\
\hline Poverty Level & $\begin{array}{c}2.160 * * \\
(.537)\end{array}$ & $\begin{array}{l}1.226 * \\
(.616)\end{array}$ & \\
\hline Racial/Ethnic Heterogeneity & $\begin{array}{l}-.518 \\
(.267)\end{array}$ & $\begin{array}{c}.483 \\
(.302)\end{array}$ & \\
\hline Female-Headed Household & $\begin{array}{l}-1.137 \\
(.730)\end{array}$ & $\begin{array}{c}4.731 * * \\
(.811)\end{array}$ & \\
\hline \multicolumn{4}{|l|}{ Individual-Level Indicators } \\
\hline Gender & $\begin{array}{l}-.046 \\
(.144)\end{array}$ & $\begin{array}{l}.346^{*} \\
(.156)\end{array}$ & $\begin{array}{l}.026 \\
(.218)\end{array}$ \\
\hline Age & $\begin{array}{c}.005 \\
(.005)\end{array}$ & $\begin{array}{l}.008 \\
(.006)\end{array}$ & $\begin{array}{l}-.016 \\
(.008)\end{array}$ \\
\hline Black & $\begin{array}{l}.180 \\
(.141)\end{array}$ & $\begin{array}{l}.445 * * \\
(.138)\end{array}$ & $\begin{array}{l}-.319 \\
(.217)\end{array}$ \\
\hline Hispanic/Latino & $\begin{array}{l}.081 \\
(.143)\end{array}$ & $\begin{array}{l}.614^{* *} \\
(.138)\end{array}$ & $\begin{array}{c}.344 \\
(.213)\end{array}$ \\
\hline Native American & $\begin{array}{l}-.024 \\
(.315)\end{array}$ & $\begin{array}{c}.055 \\
(.364)\end{array}$ & $\begin{array}{c}1.156 * * \\
(.368)\end{array}$ \\
\hline Violent Offense & $\begin{array}{l}.227 \\
(.118)\end{array}$ & $\begin{array}{l}-.065 \\
(.127)\end{array}$ & $\begin{array}{l}-.027 \\
(.184)\end{array}$ \\
\hline Ever Incarcerated & $\begin{array}{l}.317 \\
(.151)\end{array}$ & $\begin{array}{l}-.334^{*} \\
(.143)\end{array}$ & $\begin{array}{c}-.644 * * \\
(.193)\end{array}$ \\
\hline H.S. Education & $\begin{array}{l}.016 \\
(.103)\end{array}$ & $\begin{array}{c}-.273 * * \\
(.105)\end{array}$ & $\begin{array}{l}.294 \\
(.161)\end{array}$ \\
\hline Unemployed & $\begin{array}{l}.024 \\
(.099)\end{array}$ & $\begin{array}{c}.026 \\
(.101)\end{array}$ & $\begin{array}{l}-.284 \\
(.155)\end{array}$ \\
\hline Married & $\begin{array}{l}.011 \\
(.117)\end{array}$ & $\begin{array}{l}.130 \\
(.121)\end{array}$ & $\begin{array}{l}-.044 \\
(.182)\end{array}$ \\
\hline $\begin{array}{l}\text { Variance Component } \\
\text { Intercept }\end{array}$ & $.375^{*}$ & $.865 * *$ & .098 \\
\hline
\end{tabular}

\footnotetext{
${ }^{\mathrm{a}}$ White arrestees represent the reference category.
}

${ }^{\mathrm{b}}$ Chi-square $=1,386.089 ; \mathrm{df}=1,287$

${ }^{\text {c }}$ Chi-square $=1,713.122 ; \mathrm{df}=1,287$

${ }^{\mathrm{d}}$ Chi-square $=1,303.922 ; \mathrm{df}=1,290$

${ }^{*} \mathrm{p}<.05 ;{ }^{*} \mathrm{p}<.01$; Standard errors in parenthesis. 
Table 4. HLM Regression Estimates of Noncash Transactions and Method of Contact

Fixed Effects

Intercept $^{\mathrm{a}}$

Community-Level Indicators

Poverty Level

Racial/Ethnic Heterogeneity

Female-Headed Household

Individual-Level Indicators

Gender

Age

Black

Hispanic/Latino

Native American

Violent Offense

Ever Incarcerated

H.S. Education

Unemployment

Married

$\begin{array}{ccc}-1.717 * * & -1.955^{* *} & -.123 * * \\ (.046) & (.053) & (.033)\end{array}$ \\ Apt/house $^{b} \quad$ Public $^{c} \quad$ Person $^{\mathrm{d}}$}


Table 5. HLM Regression Estimates of Cash Transactions: Purchase Directly and Source

Intercept $^{\mathrm{a}}$ Direct $^{\mathrm{b}} \quad$ Regular $^{\mathrm{C}}$

\section{Fixed Effects}

Community-Level Indicators

$\begin{array}{cc}2.619 * * & .500 * * \\ (.062) & (.032)\end{array}$

Poverty Level

Racial/Ethnic Heterogeneity

Female-Headed Household

Individual-Level Indicators

\begin{tabular}{|c|c|c|}
\hline Gender & $\begin{array}{c}.292 \\
(.216)\end{array}$ & $\begin{array}{l}-.243^{*} \\
(.121)\end{array}$ \\
\hline Age & $\begin{array}{l}-.009 \\
(.008)\end{array}$ & $\begin{array}{l}.010 * \\
(.005)\end{array}$ \\
\hline Black & $\begin{array}{l}-.093 \\
(.214)\end{array}$ & $\begin{array}{l}-.094 \\
(.114)\end{array}$ \\
\hline Hispanic/Latino & $\begin{array}{l}.032 \\
(.228)\end{array}$ & $\begin{array}{l}-.250^{*} \\
(.120)\end{array}$ \\
\hline Native American & $\begin{array}{c}.835 \\
(.599)\end{array}$ & $\begin{array}{l}-.294 \\
(.255)\end{array}$ \\
\hline Violent Offense & $\begin{array}{l}-.457 * \\
(.178)\end{array}$ & $\begin{array}{l}-.045 \\
(.100)\end{array}$ \\
\hline Ever Incarcerated & $\begin{array}{l}.155 \\
(.220)\end{array}$ & $\begin{array}{l}.354^{* *} \\
(.118)\end{array}$ \\
\hline H.S. Education & $\begin{array}{l}.122 \\
(.161)\end{array}$ & $\begin{array}{l}-.021 \\
(.086)\end{array}$ \\
\hline Unemployed & $\begin{array}{l}.256 \\
(.158)\end{array}$ & $\begin{array}{l}.275^{* *} \\
(.082)\end{array}$ \\
\hline Married & $\begin{array}{l}.333 \\
(.194)\end{array}$ & $\begin{array}{l}-.005 \\
(.098)\end{array}$ \\
\hline $\begin{array}{l}\text { ance Component } \\
\text { cept }\end{array}$ & .011 & .001 \\
\hline
\end{tabular}


Table 6. HLM Regression Estimates of Cash Transaction Location Purchase

\section{Fixed Effects}

Intercept $^{\mathrm{a}}$ House $^{\mathrm{b}} \quad$ Hood $^{\mathrm{c}}$

Community-Level Indicators

Poverty Level

$\begin{array}{cc}.079 * & -.336 * * \\ \mathbf{( . 0 4 0 )} & (.034)\end{array}$

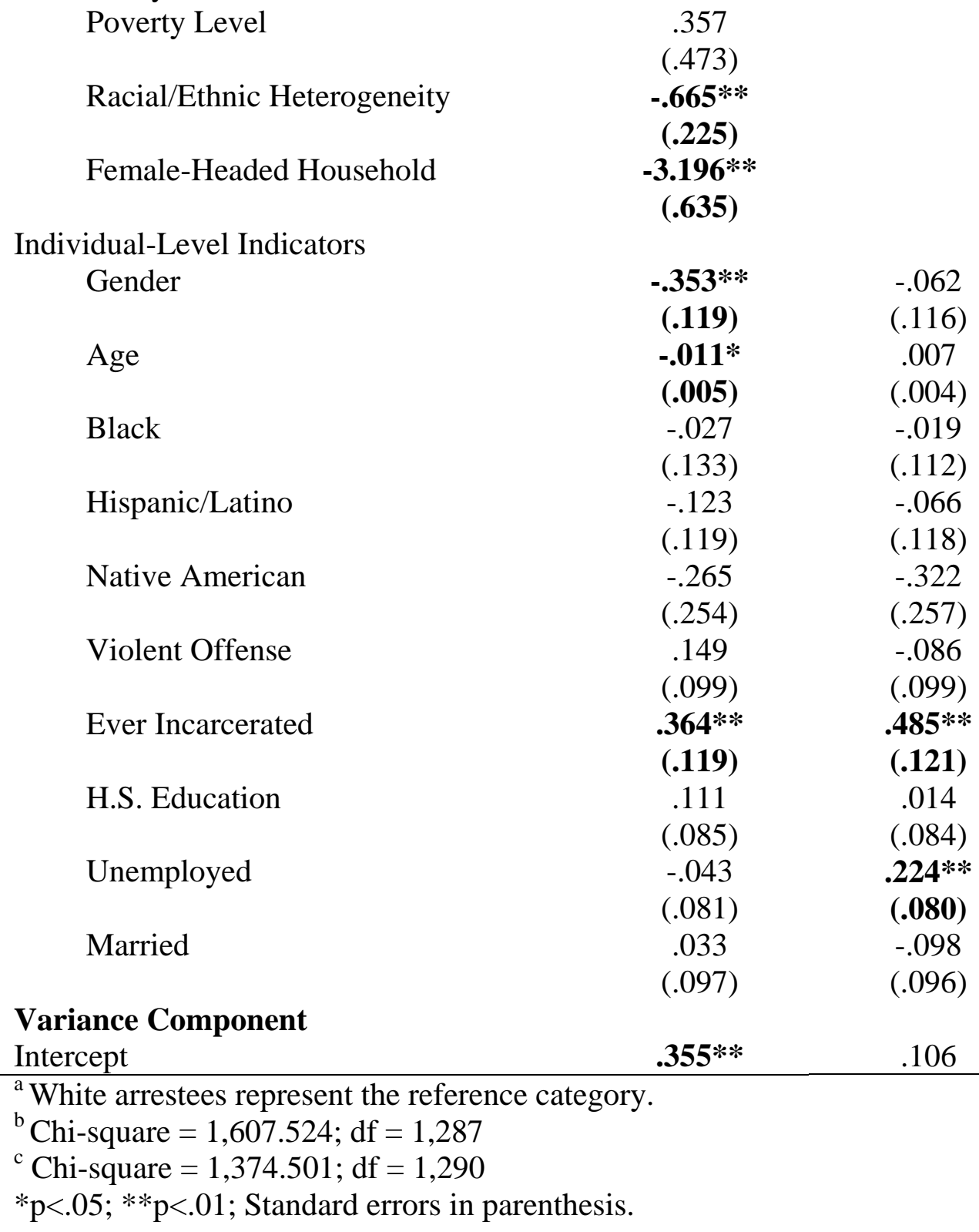


D. Heroin Models

Table 1. HLM Regression Estimates of Cash and Noncash Transactions

$\begin{array}{lcc} & \text { Cash }^{\mathrm{b}} & \text { Noncash }^{\mathrm{c}} \\ & \mathbf{1 . 7 7 5 * *} & \mathbf{- . 1 3 3 * *} \\ & \mathbf{( . 0 4 7 )} & \mathbf{( . 0 3 8 )}\end{array}$

Community-Level Indicators

Poverty Level

.422

Racial/Ethnic Heterogeneity

.214

Female-Headed Household

$-2.339 * *$

Individual-Level Indicators

(.542)

Gender

$-.125$

.126

Age

(.137)

$.017 * *$

(.006)

Black

$-.276$

(.097)

Black

(.164)

Hispanic/Latino

$-.172$

(.168)

Native American

.786

$-.013^{* *}$

Violent Offense

(.520)

(004)

Violent Offense

$-.328 *$

.212

Ever Incarcerated

(.152)

$-.215$

(.177)

H.S. Education

.110

(.118)

.090

(.121)

$-.061$

(.117)

$.467 * *$

(.124)

.082

Unemployed

(.110)

(.079)

.049

.093

(.102)

(.073)

Married

Variance Component

${ }^{a}$ White arrestees represent the reference category.

${ }^{\mathrm{b}}$ Chi-square $=1,236.725 ; \mathrm{df}=1,206$

${ }^{\text {c }}$ Chi-square $=1,357.139 ; \mathrm{df}=1,203$

${ }^{*} \mathrm{p}<.05$; ${ }^{* *} \mathrm{p}<.01$; Standard errors in parenthesis. 
Table 2. HLM Regression Estimates of Noncash Acquisition Methods

\begin{tabular}{|c|c|c|c|c|c|}
\hline \multicolumn{6}{|l|}{ Fixed Effects } \\
\hline Intercept $^{\mathrm{a}}$ & $\begin{array}{c}-1.688^{* *} \\
(.070)\end{array}$ & $\begin{array}{c}-2.614^{* *} \\
(.101)\end{array}$ & $\begin{array}{c}-1.993^{* *} \\
(.080)\end{array}$ & $\begin{array}{l}.407 * * \\
(.052)\end{array}$ & $\begin{array}{c}-4.996 * * \\
(.312)\end{array}$ \\
\hline \multicolumn{6}{|l|}{ Community-Level Indicators } \\
\hline \multicolumn{6}{|l|}{ Poverty Level } \\
\hline \multicolumn{6}{|l|}{ Racial/Ethnic Heterogeneity } \\
\hline \multicolumn{6}{|l|}{ Female-Headed Household } \\
\hline \multicolumn{6}{|l|}{ Individual-Level Indicators } \\
\hline Gender & $\begin{array}{c}.101 \\
(.246)\end{array}$ & $\begin{array}{l}.745^{*} \\
(.387)\end{array}$ & $\begin{array}{c}.535 \\
(.296)\end{array}$ & $\begin{array}{l}-.350 \\
(.188)\end{array}$ & $\begin{array}{c}-2.812^{* * *} \\
(.618)\end{array}$ \\
\hline Age & $\begin{array}{l}.020 * \\
(.010)\end{array}$ & $\begin{array}{l}-.021 \\
(.014)\end{array}$ & $\begin{array}{l}-.013 \\
(.011)\end{array}$ & $\begin{array}{l}-.003 \\
(.007)\end{array}$ & $\begin{array}{c}.021 \\
(.032)\end{array}$ \\
\hline Black & $\begin{array}{l}-.290 \\
(.296)\end{array}$ & $\begin{array}{l}.558 \\
(.403)\end{array}$ & $\begin{array}{l}-.481 \\
(.335)\end{array}$ & $\begin{array}{c}.389 \\
(.223)\end{array}$ & $\begin{array}{l}-1.120 \\
(1.032)\end{array}$ \\
\hline Hispanic/Latino & $\begin{array}{l}-.151 \\
(.297)\end{array}$ & $\begin{array}{c}.434 \\
(.429)\end{array}$ & $\begin{array}{l}-.360 \\
(.329)\end{array}$ & $\begin{array}{l}.182 \\
(.225)\end{array}$ & $\begin{array}{l}-1.597 \\
(.907)\end{array}$ \\
\hline Native American & $\begin{array}{l}.138 \\
(.674)\end{array}$ & $\begin{array}{c}.701 \\
(.912)\end{array}$ & $\begin{array}{l}-.258 \\
(.805)\end{array}$ & $\begin{array}{l}-.300 \\
(.516)\end{array}$ & $\begin{array}{c}-.138 \\
(1.927)\end{array}$ \\
\hline Violent Offense & $\begin{array}{l}-.546 \\
(.304)\end{array}$ & $\begin{array}{l}-.461 \\
(.425)\end{array}$ & $\begin{array}{l}.040 \\
(.314)\end{array}$ & $\begin{array}{c}.402 \\
(.217)\end{array}$ & $\begin{array}{c}.204 \\
(.977)\end{array}$ \\
\hline Ever Incarcerated & $\begin{array}{l}-.566 \\
(.334)\end{array}$ & $\begin{array}{c}.448 \\
(.526)\end{array}$ & $\begin{array}{l}-.372 \\
(.378)\end{array}$ & $\begin{array}{c}.454 \\
(.262)\end{array}$ & $\begin{array}{c}.896 \\
(1.213)\end{array}$ \\
\hline H.S. Education & $\begin{array}{l}-.375 \\
(.191)\end{array}$ & $\begin{array}{l}-.258 \\
(.268)\end{array}$ & $\begin{array}{c}.215 \\
(.223)\end{array}$ & $\begin{array}{l}.167 \\
(.134)\end{array}$ & $\begin{array}{c}.023 \\
(.602)\end{array}$ \\
\hline Unemployed & $\begin{array}{c}.321 \\
(.178)\end{array}$ & $\begin{array}{l}-.152 \\
(.252)\end{array}$ & $\begin{array}{l}-.100 \\
(.202)\end{array}$ & $\begin{array}{c}-.168 \\
(.134)\end{array}$ & $\begin{array}{c}.183 \\
(.566)\end{array}$ \\
\hline Married & $\begin{array}{l}.597 * * \\
(.222)\end{array}$ & $\begin{array}{l}.255 \\
(.325)\end{array}$ & $\begin{array}{l}-.016 \\
(.272)\end{array}$ & $\begin{array}{c}-.496 * * \\
(.177)\end{array}$ & $\begin{array}{l}-.592 \\
(.842)\end{array}$ \\
\hline \multicolumn{6}{|l|}{ Variance Component } \\
\hline Intercept & .195 & .341 & .375 & .102 & $.114 * *$ \\
\hline $\begin{array}{l}{ }^{\mathrm{a}} \text { White arrestees represent the refer } \\
{ }^{\mathrm{b}} \text { Chi-square }=686.073 ; \mathrm{df}=748 \\
{ }^{\mathrm{C}} \text { Chi-square }=627.959 ; \mathrm{df}=748 \\
{ }^{\mathrm{d}} \text { Chi-square }=714.175 ; \mathrm{df}=748 \\
{ }^{\mathrm{e}} \text { Chi-square }=784.067 ; \mathrm{df}=748 \\
{ }^{\mathrm{f}} \text { Chi-square }=1,051.126 ; \mathrm{df}=748 \\
{ }^{*} \mathrm{p}<.05 ; * * \mathrm{p}<.01 ; \text { Standard errors ir }\end{array}$ & category. & & & & \\
\hline
\end{tabular}


Table 3. HLM Regression Estimates of Cash Transactions and Method of Contact

\section{Fixed Effects}

Intercept $^{\mathrm{a}}$ Apt $/$ house $^{b}$ Public $^{c} \quad$ Person $^{\mathrm{d}}$

\begin{tabular}{lcccc}
\hline & Fixed Effects & Apt/house & Public $^{\mathrm{c}}$ & Person $^{\mathrm{d}}$ \\
& & & \\
Intercept $^{\mathrm{a}}$ & & $\mathbf{- 1 . 7 7 1 * *}$ & $\mathbf{- . 7 5 0 * *}$ & $-\mathbf{3 . 5 7 9 * *}$ \\
& & $\mathbf{( . 0 6 3 )}$ & $\mathbf{( . 0 6 1 )}$ & $\mathbf{( . 1 1 3 )}$
\end{tabular}

Community-Level Indicators

Poverty Level

Racial/Ethnic Heterogeneity

Female-Headed Household

Individual-Level Indicators

Gender

Age

Black

Hispanic/Latino

Native American

Violent Offense

Ever Incarcerated

H.S. Education

Unemployed

Married

$\begin{array}{cc}\mathbf{1 . 3 7 3 *} & .343 \\ \mathbf{( . 6 9 3 )} & (.729) \\ -.043 & -.503 \\ (.330) & (.334) \\ -.789 & \mathbf{- 4 . 9 0 3 * *} \\ (.873) & \mathbf{( . 9 1 2 )}\end{array}$

1.373

(.693)

$(.330)$

(.873)
(.113)

(.912)
$-.010$

(.160)

$-.006$

(.007)

$-.136$

(.195)

.003

(.191)

$-.369$

(.516)

.183

(.183)

.153

(.204)

.082

(.128)

$-.221$

(.120)

.161

(.145)
.078

(.136)

.011

(.006)

.694**

(.157)

.408*

(.171)

.975*

(.420)

.004

(.166)

-.355*

(.166)

$-.127$

(.109)

.169

(.101)

$-.147$

(.127)

$1.197 * *$
$-.064$

(.344)

$-.009$

(.015)

.167

(.432)

.460

(.413)

2.187**

(.630)

.279

(.384)

.338

(.465)

$-.181$

(.272)

$-.338$

(.259)

$-.200$

(.384)

\section{Variance Component}

.502

.434

\footnotetext{
${ }^{a}$ White arrestees represent the reference category.

${ }^{\mathrm{b}}$ Chi-square $=1,115.799 ; \mathrm{df}=1,025$

${ }^{\mathrm{c}}$ Chi-square $=1,699.128 ; \mathrm{df}=1,025$

${ }^{\mathrm{d}}$ Chi-square $=839.885 ; \mathrm{df}=1,028$

${ }^{*} \mathrm{p}<.05$; ${ }^{* *} \mathrm{p}<.01$; Standard errors in parenthesis.
} 
Table 4. HLM Regression Estimates of Noncash Transactions and Method of Contact

Fixed Effects

Intercept $^{\mathrm{a}}$ Apt/house $^{b} \quad$ Public $^{c} \quad$ Person $^{\mathrm{d}}$

Community-Level Indicators

$\begin{array}{ccc}-1.735 * * & -1.498 * * & -1.009 * * \\ (.069) & (.077) & (.055)\end{array}$

Poverty Level

1.978*

Racial/Ethnic Heterogeneity

(.810)

Female-Headed Household

$-.187$

(.390)

3.453**

Individual-Level Indicators

(1.020)

Gender

Age

Black

Hispanic/Latino

Native American

Violent Offense

Ever Incarcerated

H. S. Education

Unemployed

Married

\section{Variance Component} Intercept

\section{$-.111$}

(.249)

$-.004$

$(.010)$

$-.312$

(.305)

.201

(.300)

$-1.055$

(.835)

.336

$(.277)$

.158

(.362)

.586**

(.205)

.143

(.182)

.336

(.232)
.229

(.220)

.010

(.009)

$.514 *$

(.260)

$-.267$

(.279)

.454

(.634)

.150

(.253)

.061

(.303)

$-.314$

(.169)

.222

(.158)

$-.158$

(.216)
$-.172$

(.202)

$-.003$

(.008)

.019

(.242)

$-.244$

(.249)

.526

(.542)

.340

(.229)

.335

(.301)

$-.190$

(.159)

-.297*

(.148)

$-.389$

(.203)

\footnotetext{
${ }^{\mathrm{a}}$ White arrestees represent the reference category.

${ }^{\mathrm{b}}$ Chi-square $=721.581$; $\mathrm{df}=748$

${ }^{\mathrm{c}}$ Chi-square $=797.004 ; \mathrm{df}=745$

${ }^{\mathrm{d}}$ Chi-square $=787.729 ; \mathrm{df}=748$

${ }^{*} \mathrm{p}<.05 ;{ }^{* *} \mathrm{p}<.01$; Standard errors in parenthesis.
} 
Table 5. HLM Regression Estimates of Cash Transactions: Purchase Directly and Source

Intercept $^{\mathrm{a}}$ Direct $^{b} \quad$ Regular $^{\mathrm{C}}$

\section{Fixed Effects}

Community-Level Indicators

$\begin{array}{cc}2.838 * * & .838 * * \\ (.085) & (.038)\end{array}$

Poverty Level

.674

Racial/Ethnic Heterogeneity

Female-Headed Household

1.496

(1.169)

Individual-Level Indicators

Gender

Age

Black

Hispanic/Latino

Native American

Native American

Violent Offense

Ever Incarcerated

H.S. Education

Unemployed

Married

\section{Variance Component}

${ }^{\mathrm{a}}$ White arrestees represent the reference category.

${ }^{\mathrm{b}}$ Chi-square $=1,077.579 ; \mathrm{df}=1,025$

${ }^{\text {c }}$ Chi-square $=1,035.680 ; \mathrm{df}=1,028$

${ }^{*} \mathrm{p}<.05 ;{ }^{* *} \mathrm{p}<.01$; Standard errors in parenthesis. 
Table 6. HLM Regression Estimates of Cash Transaction Location Purchase

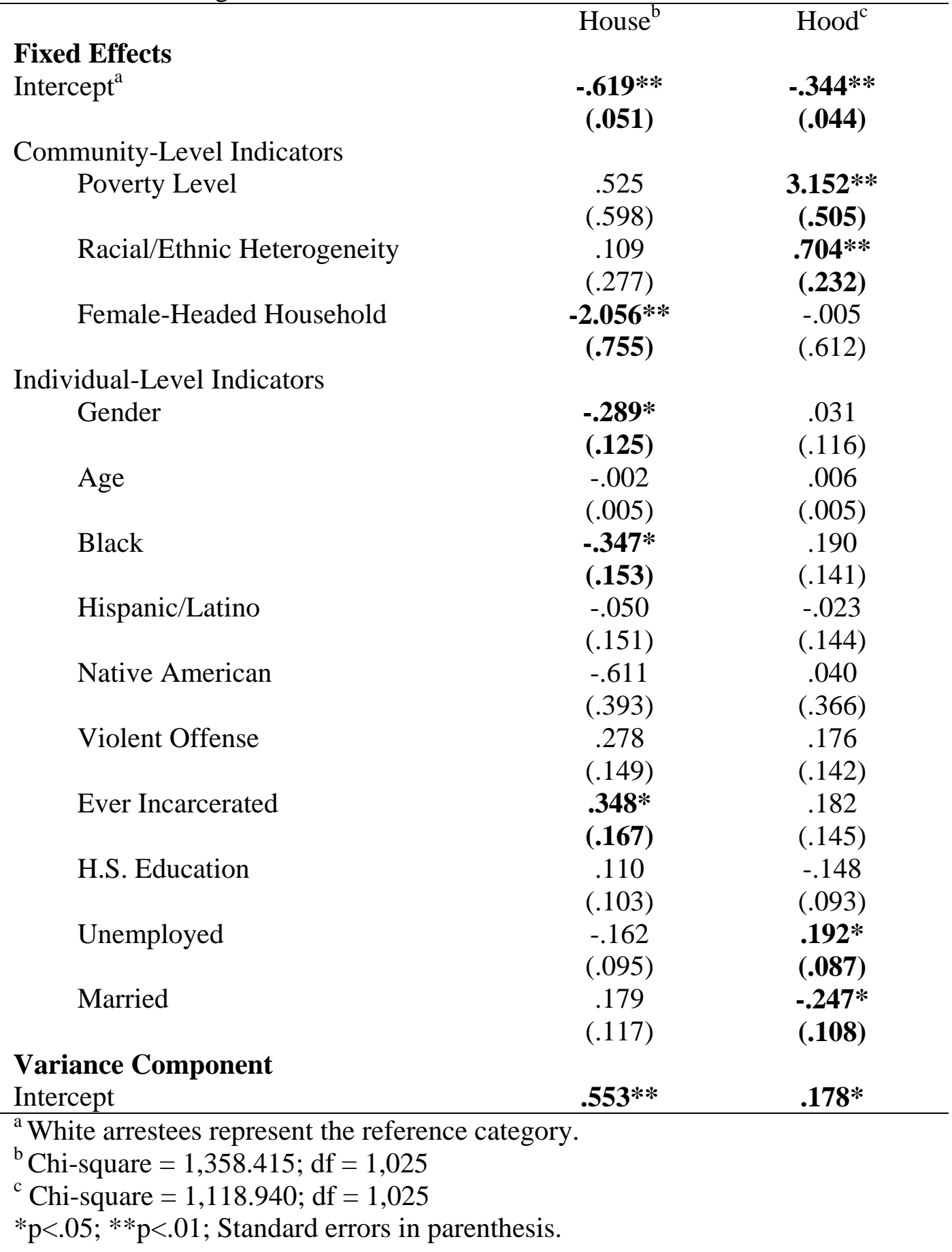




\section{E. Methamphetamines Models}

Table 1. HLM Regression Estimates of Cash and Noncash Transactions

\begin{tabular}{|c|c|c|}
\hline & $\operatorname{Cash}^{\mathrm{b}}$ & Noncash $^{\mathrm{C}}$ \\
\hline \multicolumn{3}{|l|}{ Fixed Effects } \\
\hline Intercept $^{\mathrm{a}}$ & $\begin{array}{l}.434 * * \\
(.022)\end{array}$ & $\begin{array}{c}1.218 * * \\
(.028)\end{array}$ \\
\hline \multicolumn{3}{|l|}{ Community-Level Indicators } \\
\hline Poverty Level & & $\begin{array}{l}.015 \\
(.370)\end{array}$ \\
\hline Racial/Ethnic Heterogeneity & & $\begin{array}{l}.138 \\
(.168)\end{array}$ \\
\hline Female-Headed Household & & $\begin{array}{l}.510 \\
(.676)\end{array}$ \\
\hline \multicolumn{3}{|l|}{ Individual-Level Indicators } \\
\hline Gender & $\begin{array}{l}.399 * * \\
(.060)\end{array}$ & $\begin{array}{c}-.272 * * \\
(.073)\end{array}$ \\
\hline Age & $\begin{array}{l}.024 * * \\
(.003)\end{array}$ & $\begin{array}{c}-.028 * * \\
(.003)\end{array}$ \\
\hline Black & $\begin{array}{c}-.595 * * \\
(.094)\end{array}$ & $\begin{array}{l}-.044 \\
(.110)\end{array}$ \\
\hline Hispanic/Latino & $\begin{array}{c}-.442 * * \\
(.070)\end{array}$ & $\begin{array}{l}.106 \\
(.083)\end{array}$ \\
\hline Native American & $\begin{array}{l}-.057 \\
(.186)\end{array}$ & $\begin{array}{l}.197 \\
(.226)\end{array}$ \\
\hline Violent Offense & $\begin{array}{l}-.107 \\
(.057)\end{array}$ & $\begin{array}{l}.009 \\
(.066)\end{array}$ \\
\hline Ever Incarcerated & $\begin{array}{l}.126 \\
(.067)\end{array}$ & $\begin{array}{l}.153 \\
(.078)\end{array}$ \\
\hline H.S. Education & $\begin{array}{l}.150 * * \\
(.050)\end{array}$ & $\begin{array}{l}.090 \\
(.059)\end{array}$ \\
\hline Unemployed & $\begin{array}{l}-.050 \\
(.047)\end{array}$ & $\begin{array}{l}.347^{* *} \\
(.056)\end{array}$ \\
\hline Married & $\begin{array}{l}.167 * * \\
(.058)\end{array}$ & $\begin{array}{c}-.187^{* *} \\
(.064)\end{array}$ \\
\hline $\begin{array}{l}\text { Variance Component } \\
\text { Intercept }\end{array}$ & .021 & $.047 * *$ \\
\hline
\end{tabular}

\footnotetext{
${ }^{\mathrm{a}}$ White arrestees represent the reference category.

${ }^{\mathrm{b}}$ Chi-square $=1,488.350 ; \mathrm{df}=1,437$

${ }^{\mathrm{c}}$ Chi-square $=1,597.123 ; \mathrm{df}=1,434$

${ }^{*} \mathrm{p}<.05 ;{ }^{* *} \mathrm{p}<.01$; Standard errors in parenthesis.
} 
Table 2. HLM Regression Estimates of Noncash Acquisition Methods

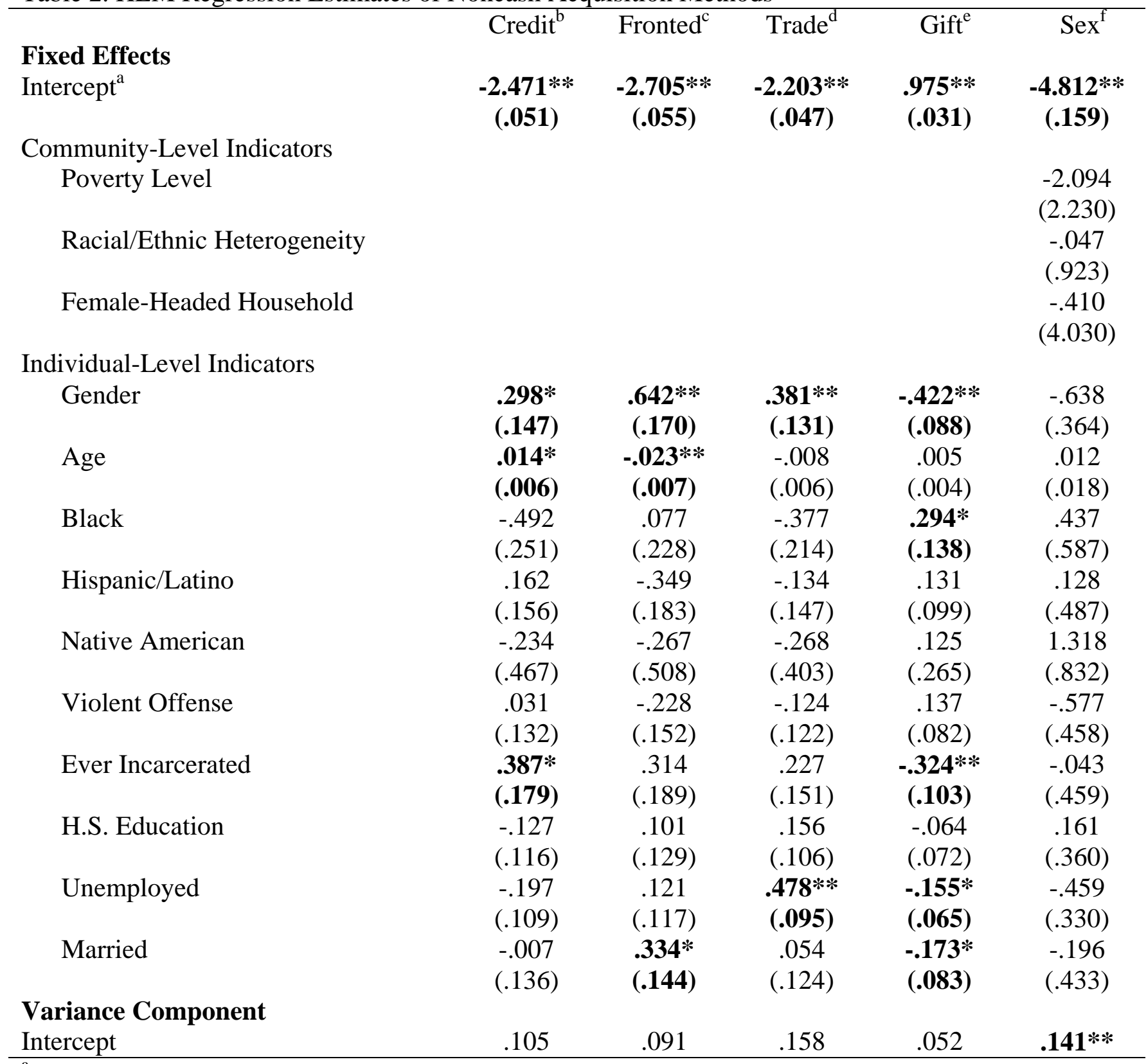

${ }^{\mathrm{a}}$ White arrestees represent the reference category.

${ }^{\mathrm{b}}$ Chi-square $=1,019.669 ; \mathrm{df}=1,143$

${ }^{\mathrm{c}}$ Chi-square $=1,025.760 ; \mathrm{df}=1,143$

${ }^{\mathrm{d}}$ Chi-square $=990.030 ; \mathrm{df}=1,143$

${ }^{\text {e }}$ Chi-square $=1,144.830 ; \mathrm{df}=1,143$

${ }^{\mathrm{f}}$ Chi-square $=1,738.928 ; \mathrm{df}=1,140$

${ }^{*} \mathrm{p}<.05 ;{ }^{* *} \mathrm{p}<.01$; Standard errors in parenthesis. 
Table 3. HLM Regression Estimates of Cash Transactions and Method of Contact

Fixed Effects

Intercept $^{\mathrm{a}}$

Community-Level Indicators

Poverty Level

Racial/Ethnic Heterogeneity

Female-Headed Household

Individual-Level Indicators

Gender

Age

Black

Hispanic/Latino

Native American

Violent Offense

Ever Incarcerated

H.S. Education

Unemployed

Married

\section{Variance Component}

$-.130$

(.110)

.007

(.005)

.099

(.178)

.061

(.122)

$-.139$

(.324)

.005

(.097)

$.356 * *$

(.127)

$-.036$

(.086)

$-.049$

(.079)

$-.160$

(.095)
$.376 *$

(.165)

.005

(.006)

$.569 *$

(.222)

.431**

(.160)

.044

(.447)

$-.204$

(.137)

$-.350 *$

(.156)

$-.152$

(.117)

$-.170$

(.110)

.095

(.129)

d

(n)

$-.089$

.002

(.006)

.086

$(.250)$

.081

(.171)

$-1.262 *$

(.592)

.122

(.134)

$-.361 *$

(.157)

.098

(.123)

$-.019$

(.111)

$-.255$

(.139)

${ }^{\mathrm{a}}$ White arrestees represent the reference category. .065

${ }^{\mathrm{b}}$ Chi-square $=1,137.229 ; \mathrm{df}=1,073$

${ }^{\mathrm{c}}$ Chi-square $=1,132.377 ; \mathrm{df}=1,073$

${ }^{\mathrm{d}}$ Chi-square $=1,063.714 ; \mathrm{df}=1,073$

${ }^{*} \mathrm{p}<.05 ;{ }^{*} \mathrm{p}<.01$; Standard errors in parenthesis. 
Table 4. HLM Regression Estimates of Noncash Transactions and Method of Contact

Intercept $^{\mathrm{a}}$

Community-Level Indicators

Poverty Level Apt/house

\section{Fixed Effects}

1.053* Public

Person $^{\mathrm{d}}$

\section{Poverty Level}

Racial/Ethnic Heterogeneity

$\begin{array}{ccc}-1.461 * * & -2.288 * * & -.323^{* *} \\ (.038) & (.051) & (.028)\end{array}$

Female-Headed Household

(.487)

$-.153$

(.230)

.409

(.879)

Individual-Level Indicators

Gender

$\mathbf{. 1 8 7} *$
$\mathbf{( . 0 9 8 )}$
.000
$(.004)$
.381

Black

-.381*

Hispanic/Latino

(.161)

.005

(.110)

Native American

$-.318$

(.312)

Violent Offense

.124

(.090)

Ever Incarcerated

.334**

H.S. Education

(.118)

$-.034$

(.081)

Unemployed

.194**

(.074)

Married

$-.085$

(.096)

$.270 *$

(.132)

.005

(.006)

.174

(.196)

.339*

(.140)

.475

(.360)

$-.083$

(.123)

.139

(.152)

$-.225 *$

(.105)

$-.002$

(.098)

.090

(.123)

Variance Component

.090*

.287

(.076)

.007*

(.004)

.153

(.120)

.080

(.089)

.100

(.236)

.019

(.074)

$-.360 * *$

(.088)

.052

(.653)

$-.237 * *$

(.060)

-.182*

(.077)

\footnotetext{
${ }^{\mathrm{a}}$ White arrestees represent the reference category.

${ }^{\mathrm{b}}$ Chi-square $=$,1242.188; $\mathrm{df}=1,140$

${ }^{\mathrm{c}}$ Chi-square $=1,090.272 ; \mathrm{df}=1,143$

${ }^{\mathrm{d}}$ Chi-square $=1,213.840 ; \mathrm{df}=1,143$

${ }^{*} \mathrm{p}<.05 ;{ }^{* *} \mathrm{p}<.01$; Standard errors in parenthesis.
} 
Table 5. HLM Regression Estimates of Cash Transactions: Purchase Directly and Source

\section{Fixed Effects}

Intercept $^{\mathrm{a}}$

Community-Level Indicators

Poverty Level

Racial/Ethnic Heterogeneity

Female-Headed Household

Individual-Level Indicators

Gender Direct $^{\mathrm{b}} \quad$ Regular $^{\mathrm{C}}$

\section{$2.425 * *$}

(.053)
$.279 * *$

(.029)
$-.158$

Age

(.167)

(.096)

$-.009$

$-.000$

Black

(.007)

(.004)

Hispanic/Latino

$-.272$

$-.369 *$

(.262)

Native American

$-.156$

(.154)

Native American

$-.268 *$

Violent Offense

Ever Incarcerated

H.S. Education

Unemployed

$$
-.012
$$

Married

\section{Variance Component}

${ }^{\mathrm{a}}$ White arrestees represent the reference category.

${ }^{\mathrm{b}}$ Chi-square $=913.389 ; \mathrm{df}=1,073$

${ }^{\mathrm{c}}$ Chi-square $=1,113.108$; $\mathrm{df}=1,073$

${ }^{*} \mathrm{p}<.05 ;{ }^{* *} \mathrm{p}<.01$; Standard errors in parenthesis. 
Table 6. HLM Regression Estimates of Cash Transaction Location Purchase

\begin{tabular}{|c|c|c|}
\hline & House $^{b}$ & $\operatorname{Hood}^{\mathrm{C}}$ \\
\hline \multicolumn{3}{|l|}{ Fixed Effects } \\
\hline \multirow[t]{2}{*}{ Intercept $^{\mathrm{a}}$} & $1.041 * *$ & $-.504 * *$ \\
\hline & $(.040)$ & $(.036)$ \\
\hline \multicolumn{3}{|l|}{ Community-Level Indicators } \\
\hline \multirow[t]{2}{*}{ Poverty Level } & -.514 & $1.447 * *$ \\
\hline & $(.513)$ & $(.477)$ \\
\hline \multirow[t]{2}{*}{ Racial/Ethnic Heterogeneity } & $-1.080 * *$ & $.565 * *$ \\
\hline & (.239) & $(.216)$ \\
\hline \multirow[t]{2}{*}{ Female-Headed Household } & .382 & .329 \\
\hline & $(.964)$ & $(.885)$ \\
\hline \multicolumn{3}{|l|}{ Individual-Level Indicators } \\
\hline \multirow[t]{2}{*}{ Gender } & $-.317 * *$ & .065 \\
\hline & $(.109)$ & $(.097)$ \\
\hline \multirow[t]{2}{*}{ Age } & .003 & $.012 * *$ \\
\hline & $(.004)$ & $(.004)$ \\
\hline \multirow[t]{2}{*}{ Black } & $-.352 *$ & $-.346 *$ \\
\hline & $(.165)$ & (.160) \\
\hline \multirow[t]{2}{*}{ Hispanic/Latino } & $-.293 *$ & -.161 \\
\hline & $(.112)$ & $(.107)$ \\
\hline \multirow[t]{2}{*}{ Native American } & -.345 & -.096 \\
\hline & $(.295)$ & $(.279)$ \\
\hline \multirow[t]{2}{*}{ Violent Offense } & -.004 & .125 \\
\hline & $(.092)$ & $(.085)$ \\
\hline \multirow[t]{2}{*}{ Ever Incarcerated } & $.359 * *$ & $.332 * *$ \\
\hline & (.110) & $(.108)$ \\
\hline \multirow[t]{2}{*}{ H.S. Education } & .156 & -.084 \\
\hline & $(.081)$ & $(.075)$ \\
\hline \multirow[t]{2}{*}{ Unemployed } & .079 & .067 \\
\hline & $(.075)$ & $(.069)$ \\
\hline \multirow{2}{*}{ Married } & .046 & $-.169 *$ \\
\hline & $(.091)$ & (.083) \\
\hline \multicolumn{3}{|l|}{ Variance Component } \\
\hline Intercept & $.161 * *$ & $.137 * *$ \\
\hline \multicolumn{3}{|c|}{${ }^{\mathrm{a}}$ White arrestees represent the reference category. } \\
\hline \multicolumn{3}{|c|}{${ }^{\mathrm{b}}$ Chi-square $=1,227.551 ; \mathrm{df}=1,070$} \\
\hline \multicolumn{3}{|l|}{${ }^{\mathrm{c}}$ Chi-square $=1,235.190 ; \mathrm{df}=1,070$} \\
\hline${ }^{*} \mathrm{p}<.05 ; * * \mathrm{p}<.01 ;$ Standard errors in 1 & & \\
\hline
\end{tabular}


This document is a research report submitted to the U.S. Department of Justice. This report has not been published by the Department. Opinions or points of view expressed are those of the author(s) and do not necessarily reflect the official position or policies of the U.S. Department of Justice.

APPENDIX C. Female Models 


\section{A. Marijuana Models}

Table 1. HLM Regression Estimates of Cash and Noncash Transactions

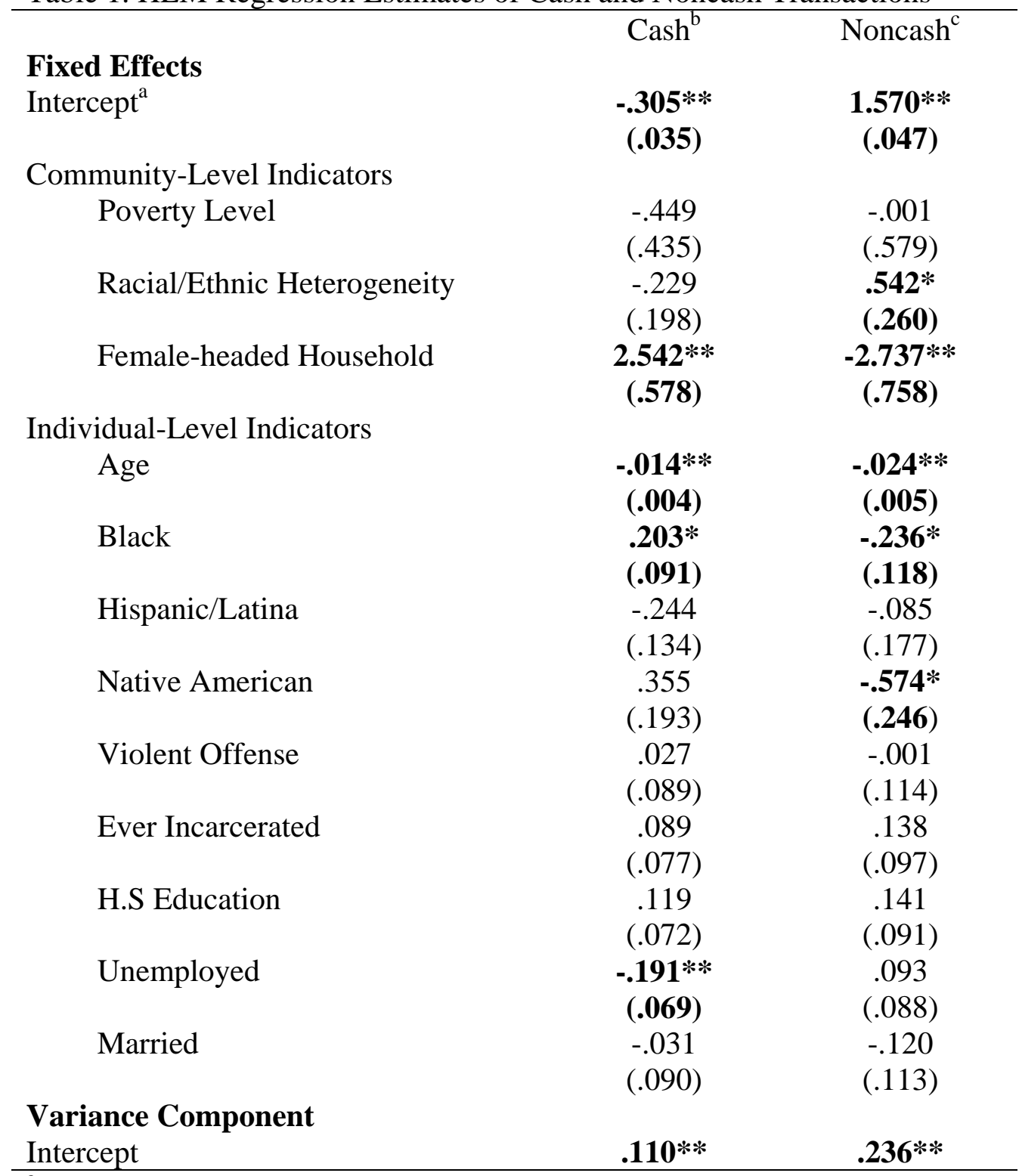

${ }^{\mathrm{a}}$ White arrestees represent the reference category.

${ }^{\mathrm{b}}$ Chi-square $=1,282.520 ; \mathrm{df}=1,127$

${ }^{\mathrm{c}}$ Chi-square $=1,318.819 ; \mathrm{df}=1,127$

${ }^{*} \mathrm{p}<.05 ;{ }^{* *} \mathrm{p}<.01$; Standard errors in parentheses. 
Table 2. HLM Regression Estimates of Noncash Acquisition Methods

\section{Fixed Effects}

Intercept $^{\mathrm{a}}$ Credit $^{\mathrm{b}} \quad$ Trade $^{\mathrm{c}}$

Gift $^{\mathrm{d}}$

Community-Level Indicators

$\begin{array}{cc}-3.220 * * & -3.598 * * \\ (.095) & (.112)\end{array}$

Poverty Level

Racial/Ethnic Heterogeneity

Female-Headed Household

Individual-Level Indicators

\begin{tabular}{|c|c|c|c|}
\hline Age & $\begin{array}{l}-.028 * \\
(.013)\end{array}$ & $\begin{array}{l}.010 \\
(.014)\end{array}$ & $\begin{array}{c}.008 \\
(.008)\end{array}$ \\
\hline Black & $\begin{array}{l}.631 * \\
(.282)\end{array}$ & $\begin{array}{l}-.344 \\
(.329)\end{array}$ & $\begin{array}{c}.165 \\
(.182)\end{array}$ \\
\hline Hispanic/Latina & $\begin{array}{c}.538 \\
(.395)\end{array}$ & $\begin{array}{c}.135 \\
(.463)\end{array}$ & $\begin{array}{l}-.060 \\
(.258)\end{array}$ \\
\hline Native American & $\begin{array}{l}.733 \\
(.556)\end{array}$ & $\begin{array}{l}.056 \\
(.701)\end{array}$ & $\begin{array}{l}-.131 \\
(.382)\end{array}$ \\
\hline Violent Offense & $\begin{array}{l}.129 \\
(.267)\end{array}$ & $\begin{array}{l}-.161 \\
(.341)\end{array}$ & $\begin{array}{c}.052 \\
(.183)\end{array}$ \\
\hline Ever Incarcerated & $\begin{array}{c}.393 \\
(.248)\end{array}$ & $\begin{array}{l}.696 * \\
(.315)\end{array}$ & $\begin{array}{c}-.628 * * \\
(.168)\end{array}$ \\
\hline H.S. Education & $\begin{array}{l}-.070 \\
(.216)\end{array}$ & $\begin{array}{c}.460 \\
(.271)\end{array}$ & $\begin{array}{l}-.065 \\
(.143)\end{array}$ \\
\hline Unemployed & $\begin{array}{l}.156 \\
(.205)\end{array}$ & $\begin{array}{l}.463 * \\
(.242)\end{array}$ & $\begin{array}{l}-.333^{*} \\
(.134)\end{array}$ \\
\hline Married & $\begin{array}{l}-.007 \\
(.290)\end{array}$ & $\begin{array}{l}.602 * \\
(.292)\end{array}$ & $\begin{array}{c}-.334 * \\
\text { (.174) }\end{array}$ \\
\hline rcept & .248 & .098 & .086 \\
\hline
\end{tabular}

Intercept

${ }^{\mathrm{a}}$ White arrestees represent the reference category.

${ }^{\mathrm{b}}$ Chi-square $=776.105 ; \mathrm{df}=933$

${ }^{\mathrm{c}}$ Chi-square $=913.986 ; \mathrm{df}=933$

${ }^{\mathrm{d}}$ Chi-square $=934.742 ; \mathrm{df}=933$

${ }^{*} \mathrm{p}<.05 ;{ }^{* *} \mathrm{p}<.01$; Standard errors in parenthesis. 
Table 3. HLM Regression Estimates of Cash Transactions and Method of Contact

\begin{tabular}{|c|c|c|c|}
\hline & Apt/house ${ }^{b}$ & Public $^{c}$ & Person $^{d}$ \\
\hline \multicolumn{4}{|l|}{ Fixed Effects } \\
\hline Intercept $^{\mathrm{a}}$ & $\begin{array}{c}-1.234^{* *} \\
(.066)\end{array}$ & $\begin{array}{c}-1.464 * * \\
(.082)\end{array}$ & $\begin{array}{c}-2.198 * * \\
(0.087)\end{array}$ \\
\hline \multicolumn{4}{|l|}{ Community-Level Indicators } \\
\hline Poverty Level & & $\begin{array}{c}2.438 * * \\
(.907)\end{array}$ & \\
\hline Racial/Ethnic Heterogeneity & & $\begin{array}{l}.305 \\
(.441)\end{array}$ & \\
\hline Female-Headed Household & & $\begin{array}{l}5.308 * * \\
(1.192)\end{array}$ & \\
\hline \multicolumn{4}{|l|}{ Individual-Level Indicators } \\
\hline Age & $\begin{array}{l}-.018 \\
(.010)\end{array}$ & $\begin{array}{l}.009 \\
(.010)\end{array}$ & $\begin{array}{c}.004 \\
(.013)\end{array}$ \\
\hline Black & $\begin{array}{l}.144 \\
(.210)\end{array}$ & $\begin{array}{l}.832 * * \\
(.213)\end{array}$ & $\begin{array}{l}-.302 \\
(.288)\end{array}$ \\
\hline Hispanic/Latina & $\begin{array}{l}-.304 \\
(.380)\end{array}$ & $\begin{array}{l}.737^{*} \\
(.390)\end{array}$ & $\begin{array}{l}-.011 \\
(.503)\end{array}$ \\
\hline Native American & $\begin{array}{c}-1.215^{* *} \\
(.456)\end{array}$ & $\begin{array}{l}.573 \\
(.470)\end{array}$ & $\begin{array}{c}.596 \\
(.546)\end{array}$ \\
\hline Violent Offense & $\begin{array}{l}.390 \\
(.202)\end{array}$ & $\begin{array}{l}-.430 * \\
(.216)\end{array}$ & $\begin{array}{l}.263 \\
(.276)\end{array}$ \\
\hline Ever Incarcerated & $\begin{array}{l}.147 \\
(.183)\end{array}$ & $\begin{array}{l}.044 \\
(.183)\end{array}$ & $\begin{array}{l}-.533^{*} \\
(.240)\end{array}$ \\
\hline H.S. Education & $\begin{array}{l}-.163 \\
(.163)\end{array}$ & $\begin{array}{l}-.045 \\
(.160)\end{array}$ & $\begin{array}{l}.239 \\
(.229)\end{array}$ \\
\hline Unemployed & $\begin{array}{l}.374 * \\
(.162)\end{array}$ & $\begin{array}{c}.073 \\
(.162)\end{array}$ & $\begin{array}{l}-.200 \\
(.229)\end{array}$ \\
\hline Married & $\begin{array}{l}.101 \\
(.212)\end{array}$ & $\begin{array}{l}.144 \\
(.215)\end{array}$ & $\begin{array}{l}-.293 \\
(.310)\end{array}$ \\
\hline $\begin{array}{l}\text { Variance Component } \\
\text { Intercept }\end{array}$ & .326 & $.528 * *$ & .237 \\
\hline
\end{tabular}

\footnotetext{
${ }^{\mathrm{a}}$ White arrestees represent the reference category.

${ }^{\mathrm{b}}$ Chi-square $=689.221 ; \mathrm{df}=662$

${ }^{\mathrm{c}}$ Chi-square $=755.240 ; \mathrm{df}=659$

${ }^{\mathrm{d}}$ Chi-square $=684.435 ; \mathrm{df}=662$

${ }^{*} \mathrm{p}<.05 ;{ }^{*} \mathrm{p}<.01$; Standard errors in parenthesis.
} 
Table 4. HLM Regression Estimates of Noncash Transactions and Method of Contact

Intercept $^{\mathrm{a}}$ Apt/house $^{\mathrm{b}} \quad$ Public $^{\mathrm{c}} \quad$ Person $^{\mathrm{d}}$

\section{Fixed Effects}

Community-Level Indicators

$\begin{array}{ccc}-1.869 * * & -2.013 * * & .326 * * \\ (.053) & (.060) & (.037)\end{array}$

Poverty Level

Racial/Ethnic Heterogeneity

Female-Headed Household

Individual-Level Indicators

\begin{tabular}{|c|c|c|c|}
\hline Age & $\begin{array}{c}.002 \\
(.007)\end{array}$ & $\begin{array}{l}-.010 \\
(.008)\end{array}$ & $\begin{array}{c}.014^{* *} \\
(.005)\end{array}$ \\
\hline Black & $\begin{array}{c}.072 \\
(.163)\end{array}$ & $\begin{array}{l}.452 * * \\
(.170)\end{array}$ & $-.290 *$ \\
\hline Hispanic/Latina & $\begin{array}{c}.302 \\
(.225)\end{array}$ & $\begin{array}{l}-.164 \\
(.254)\end{array}$ & $\begin{array}{l}-.004 \\
(.162)\end{array}$ \\
\hline Native American & $\begin{array}{l}-.095 \\
(.362)\end{array}$ & $\begin{array}{c}.497 \\
(.347)\end{array}$ & $\begin{array}{l}-.462 \\
(.244)\end{array}$ \\
\hline Violent Offense & $\begin{array}{c}.223 \\
(.156)\end{array}$ & $\begin{array}{l}-.147 \\
(.174)\end{array}$ & $\begin{array}{l}-.194 \\
(.111)\end{array}$ \\
\hline Ever Incarcerated & $\begin{array}{l}.309 * \\
(.143)\end{array}$ & $\begin{array}{c}.169 \\
(.147)\end{array}$ & $\begin{array}{c}-.413 * * \\
(.097)\end{array}$ \\
\hline H.S. Education & $\begin{array}{l}-.035 \\
(.128)\end{array}$ & $\begin{array}{l}-.262^{*} \\
(.132)\end{array}$ & $\begin{array}{l}.072 \\
(.089)\end{array}$ \\
\hline Unemployed & $\begin{array}{l}.140 \\
(.120)\end{array}$ & $\begin{array}{l}.256^{*} \\
(.125)\end{array}$ & $\begin{array}{l}-.166 * \\
(.084)\end{array}$ \\
\hline Married & $\begin{array}{l}.357^{*} \\
(.154)\end{array}$ & $\begin{array}{l}-.366^{*} \\
(.187)\end{array}$ & $\begin{array}{l}-.138 \\
(.114)\end{array}$ \\
\hline
\end{tabular}

\section{Variance Component}

.094

.288

\footnotetext{
${ }^{\mathrm{a}}$ White arrestees represent the reference category.

${ }^{\mathrm{b}}$ Chi-square $=894.179 ; \mathrm{df}=933$

${ }^{\mathrm{c}}$ Chi-square $=932.005 ; \mathrm{df}=933$

${ }^{\mathrm{d}}$ Chi-square $=956.464 ; \mathrm{df}=933$

${ }^{*} \mathrm{p}<.05 ;{ }^{* *} \mathrm{p}<.01$; Standard errors in parenthesis.
} 
Table 5. HLM Regression Estimates of Cash Transactions: Purchase Directly and Source

\section{Fixed Effects}

Intercept $^{\mathrm{a}}$

Community-Level Indicators

Poverty Level

Racial/Ethnic Heterogeneity

Female-Headed Household

Individual-Level Indicators

$\begin{array}{lcc}\text { Age } & -.007 & -.002 \\ \text { Black } & (.017) & (.008) \\ & .321 & -.144 \\ \text { Hispanic/Latina } & (.374) & (.177) \\ & -.662 & -.500 \\ \text { Native American } & .587) & (.317) \\ & .560 & -.770 * \\ \text { Violent Offense } & (.782) & \mathbf{( . 3 6 7 )} \\ & -.612 & \mathbf{. 5 3 0 * *} \\ \text { Ever Incarcerated } & .341) & \mathbf{( . 1 8 0 )} \\ & -.263 & \mathbf{. 4 2 8 * *} \\ \text { H.S. Education } & (.331) & \mathbf{( . 1 5 4 )} \\ & .244 & -.026 \\ \text { Unemployed } & (.289) & \mathbf{( . 1 3 8 )} \\ \text { Married } & -.111 & -.026 \\ & (.290) & \mathbf{( . 1 3 8 )} \\ & .303 & \mathbf{. 5 8 3 * *} \\ & (.401) & \mathbf{( . 1 8 6 )}\end{array}$

Variance Component

$\begin{array}{cc}2.838 * * & .278 * * \\ (.113) & (.052)\end{array}$

\section{Direct $^{\mathrm{b}} \quad$ Regular $^{\mathrm{c}}$}

Intercept

.313

.066

${ }^{\mathrm{a}}$ White arrestees represent the reference category.

${ }^{\mathrm{b}}$ Chi-square $=597.975 ; \mathrm{df}=662$

${ }^{\mathrm{c}}$ Chi-square $=660.189 ; \mathrm{df}=662$

${ }^{*} \mathrm{p}<.05 ;{ }^{* *} \mathrm{p}<.01$; Standard errors in parenthesis. 
Table 6. HLM Regression Estimates of Cash Transaction Location Purchase

\begin{tabular}{|c|c|c|}
\hline & House $^{b}$ & $\operatorname{Hood}^{\mathrm{C}}$ \\
\hline \multicolumn{3}{|l|}{ Fixed Effects } \\
\hline \multirow[t]{2}{*}{ Intercept $^{\mathrm{a}}$} & $.558 * *$ & $-.253 * *$ \\
\hline & $(.063)$ & (.058) \\
\hline \multicolumn{3}{|l|}{ Community-Level Indicators } \\
\hline \multirow[t]{2}{*}{ Poverty Level } & $-1.962 *$ & $1.939 * *$ \\
\hline & $(.775)$ & $(.723)$ \\
\hline \multirow[t]{2}{*}{ Racial/Ethnic Heterogeneity } & .049 & .527 \\
\hline & $(.356)$ & $(.329)$ \\
\hline \multirow[t]{2}{*}{ Female-Headed Household } & $-3.223 * *$ & $1.850 *$ \\
\hline & (1.008) & $(.940)$ \\
\hline \multicolumn{3}{|l|}{ Individual-Level Indicators } \\
\hline \multirow[t]{2}{*}{ Age } & .002 & .009 \\
\hline & $(.009)$ & $(.008)$ \\
\hline \multirow[t]{2}{*}{ Black } & $-.579 * *$ & -.208 \\
\hline & $(.183)$ & $(.177)$ \\
\hline \multirow[t]{2}{*}{ Hispanic/Latina } & -.110 & -.225 \\
\hline & $(.333)$ & $(.316)$ \\
\hline \multirow[t]{2}{*}{ Native American } & $-1.267 * *$ & $-.922 *$ \\
\hline & (.386) & $(.377)$ \\
\hline \multirow[t]{2}{*}{ Violent Offense } & .207 & -.279 \\
\hline & $(.186)$ & $(.177)$ \\
\hline \multirow[t]{2}{*}{ Ever Incarcerated } & -.130 & .034 \\
\hline & $(.161)$ & $(.154)$ \\
\hline \multirow[t]{2}{*}{ H.S. Education } & .045 & .078 \\
\hline & $(.143)$ & $(.139)$ \\
\hline \multirow[t]{2}{*}{ Unemployed } & .012 & .185 \\
\hline & $(.144)$ & (.139) \\
\hline \multirow[t]{2}{*}{ Married } & .057 & -.027 \\
\hline & (.189) & $(.181)$ \\
\hline \multicolumn{3}{|l|}{ Variance Component } \\
\hline Intercept & $.321 * *$ & .178 \\
\hline
\end{tabular}

\footnotetext{
${ }^{\mathrm{a}}$ White arrestees represent the reference category.

${ }^{\mathrm{b}}$ Chi-square $=770.285 ; \mathrm{df}=659$

${ }^{\mathrm{c}}$ Chi-square $=717.828 ; \mathrm{df}=659$

${ }^{*} \mathrm{p}<.05 ;{ }^{* *} \mathrm{p}<.01$; Standard errors in parenthesis.
} 


\section{B. Crack Models}

Table 1. HLM Regression Estimates of Cash and Noncash Transactions

\section{Fixed Effects}

Intercept $^{\mathrm{a}}$

Community-Level Indicators

$$
\text { Cash }^{\mathrm{b}}
$$

$1.462 * *$

(.050)

Poverty Level

Racial/Ethnic Heterogeneity

Female-Headed Household

Individual-Level Indicators

Age

.010

$(.007)$

Black

$-.139$

(.141)

Hispanic/Latina

$-.014$

(.233)

Native American

$-.849 * *$

Violent Offense

(.320)

$-.257$

(.164)

Ever Incarcerated

$.577 * *$

(.144)

H.S. Education

Unemployed

.065

(.110)

.272*

(.105)

Married
.272

(.105)
Noncash $^{\mathrm{C}}$

$.560 * *$

(.047)

$-.708$

(.539)

$-.221$

(.265)

$-2.076 * *$

(.696)

\section{Variance Component}

$-.008$

(.189)

\footnotetext{
${ }^{\mathrm{a}}$ White arrestees represent the reference category.

${ }^{\mathrm{b}}$ Chi-square $=867.581 ; \mathrm{df}=811$

${ }^{\mathrm{c}}$ Chi-square $=937.616 ; \mathrm{df}=808$

${ }^{*} \mathrm{p}<.05 ;{ }^{* *} \mathrm{p}<.01$; Standard errors in parenthesis.
} 
Table 2. HLM Regression Estimates of Noncash Acquisition Methods

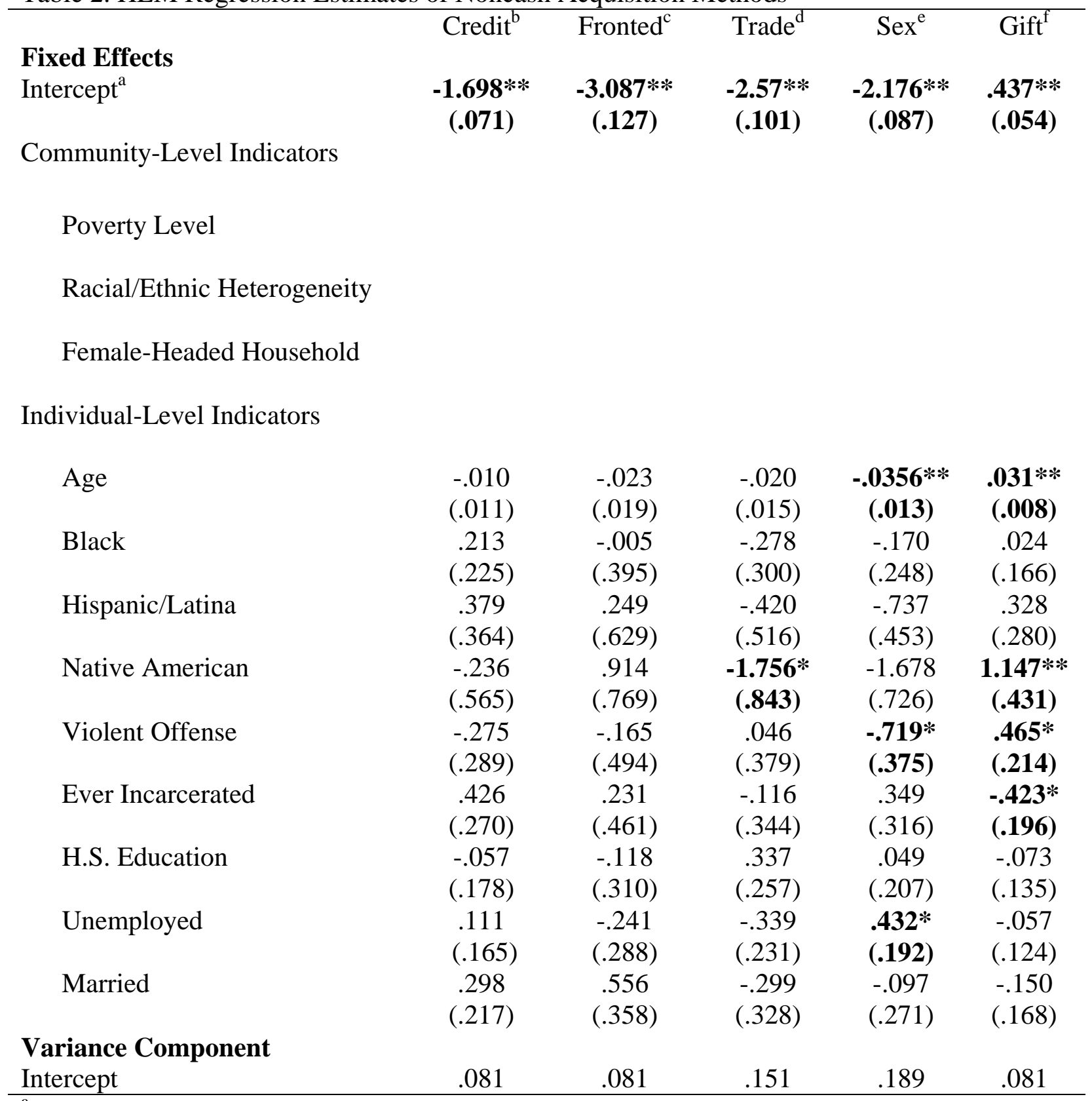

${ }^{\mathrm{a}}$ White arrestees represent the reference category.

${ }^{\mathrm{b}}$ Chi-square $=601.564 ; \mathrm{df}=573$

${ }^{\mathrm{c}}$ Chi-square $=601.564 ; \mathrm{df}=573$

${ }^{\mathrm{d}}$ Chi-square $=570.177 ; \mathrm{df}=573$

${ }^{\mathrm{e}}$ Chi-square $=504.612 ; \mathrm{df}=573$

${ }^{\mathrm{f}}$ Chi-square $=614.413 ; \mathrm{df}=573$

${ }^{*} \mathrm{p}<.05 ;{ }^{* *} \mathrm{p}<.01$; Standard errors in parenthesis. 
Table 3. HLM Regression Estimates of Cash Transactions and Method of Contact

\section{Fixed Effects}

Intercept $^{\mathrm{a}}$

Apt/house $^{\mathrm{b}} \quad$ Public $^{\mathrm{c}} \quad$ Person $^{\mathrm{d}}$

Community-Level Indicators

$\begin{array}{ccc}-1.078 * * & -.821 * * & -2.966 * * \\ (.066) & (.069) & (.104)\end{array}$

Poverty Level

1.090

1.205

Racial/Ethnic Heterogeneity

(.758)

(.786)

Remale-Headed Household

.115

$-.122$

Female-Headed Household

Individual-Level Indicators

\begin{tabular}{|c|c|c|c|}
\hline Age & $\begin{array}{c}-.006 \\
(.008)\end{array}$ & $\begin{array}{c}.013 \\
(.008)\end{array}$ & $\begin{array}{l}-.012 \\
(.016)\end{array}$ \\
\hline \multirow[t]{2}{*}{ Black } & -.238 & $.609 * *$ & .012 \\
\hline & $(.158)$ & $(.151)$ & $(.305)$ \\
\hline \multirow[t]{2}{*}{ Hispanic/Latina } & .034 & .224 & -.144 \\
\hline & $(.265)$ & $(.272)$ & $(.520)$ \\
\hline \multirow[t]{2}{*}{ Native American } & -1.085 & $1.285 * *$ & -1.113 \\
\hline & $(.569)$ & $(.490)$ & (1.145) \\
\hline \multirow[t]{2}{*}{ Violent Offense } & .104 & -.084 & -.027 \\
\hline & $(.212)$ & (.199) & $(.408)$ \\
\hline \multirow[t]{2}{*}{ Ever Incarcerated } & .128 & -.234 & .143 \\
\hline & $(.195)$ & $(.172)$ & $(.374)$ \\
\hline \multirow[t]{2}{*}{ H.S. Education } & .072 & $-.347 * *$ & -.239 \\
\hline & $(.129)$ & $(.117)$ & $(.243)$ \\
\hline \multirow[t]{2}{*}{ Unemployed } & .081 & .175 & .041 \\
\hline & $(.123)$ & $(.112)$ & $(.234)$ \\
\hline \multirow[t]{2}{*}{ Married } & .119 & -.038 & .138 \\
\hline & $(.163)$ & $(.154)$ & $(.306)$ \\
\hline \multicolumn{4}{|l|}{ iriance Component } \\
\hline ercept & $.462 * *$ & $.628 * *$ & .277 \\
\hline
\end{tabular}

${ }^{\mathrm{a}}$ White arrestees represent the reference category.

${ }^{\mathrm{b}}$ Chi-square $=782.413 ; \mathrm{df}=644$

${ }^{\mathrm{c}}$ Chi-square $=868.558 ; \mathrm{df}=644$

${ }^{\mathrm{d}}$ Chi-square $=632.302 ; \mathrm{df}=659$

${ }^{*} \mathrm{p}<.05 ;{ }^{* *} \mathrm{p}<.01$; Standard errors in parenthesis. 
Table 4. HLM Regression Estimates of Noncash Transactions and Method of Contact

\section{Fixed Effects}

Intercept $^{\mathrm{a}}$ Apt/house ${ }^{b} \quad$ Public $^{c} \quad$ Person $^{d}$

Community-Level Indicators

$\begin{array}{ccc}-1.569 * * & -1.486 * * & -0.53 * * \\ (.070) & (.072) & (.051)\end{array}$

Poverty Level

Racial/Ethnic Heterogeneity

Female-Headed Household

Individual-Level Indicators

\begin{tabular}{|c|c|c|c|}
\hline Age & $\begin{array}{c}.017 \\
(.010)\end{array}$ & $\begin{array}{l}-.018 \\
(.010)\end{array}$ & $\begin{array}{l}.017 * \\
(.008)\end{array}$ \\
\hline Black & $\begin{array}{c}.093 \\
(.217)\end{array}$ & $\begin{array}{c}.353 \\
(.207)\end{array}$ & $\begin{array}{l}-.104 \\
(.169)\end{array}$ \\
\hline Hispanic/Latina & $\begin{array}{c}.494 \\
(.342)\end{array}$ & $\begin{array}{l}-.191 \\
(.364)\end{array}$ & $\begin{array}{c}.053 \\
(.281)\end{array}$ \\
\hline Native American & $\begin{array}{l}-.880 \\
(.592)\end{array}$ & $\begin{array}{l}-.143 \\
(.517)\end{array}$ & $\begin{array}{l}.859 * \\
(.398)\end{array}$ \\
\hline Violent Offense & $\begin{array}{c}.419 \\
(.250)\end{array}$ & $\begin{array}{l}-.114 \\
(.257)\end{array}$ & $\begin{array}{c}.181 \\
(.205)\end{array}$ \\
\hline Ever Incarcerated & $\begin{array}{c}.293 \\
(.255)\end{array}$ & $\begin{array}{l}-.029 \\
(.231)\end{array}$ & $\begin{array}{l}-.340 \\
(.188)\end{array}$ \\
\hline H.S. Education & $\begin{array}{c}.154 \\
(.175)\end{array}$ & $\begin{array}{c}-.175 \\
(.163)\end{array}$ & $\begin{array}{c}.066 \\
(.135)\end{array}$ \\
\hline Unemployed & $\begin{array}{c}.171 \\
(.160)\end{array}$ & $\begin{array}{c}.210 \\
(.152)\end{array}$ & $\begin{array}{c}-.131 \\
(.124)\end{array}$ \\
\hline Married & $\begin{array}{c}.252 \\
(.209)\end{array}$ & $\begin{array}{l}-.308 \\
(.219)\end{array}$ & $\begin{array}{c}.126 \\
(.168)\end{array}$ \\
\hline & .124 & .308 & .003 \\
\hline
\end{tabular}

${ }^{\mathrm{a}}$ White arrestees represent the reference category.

${ }^{\mathrm{b}}$ Chi-square $=575.375 ; \mathrm{df}=570$

${ }^{\mathrm{c}}$ Chi-square $=593.545 ; \mathrm{df}=573$

${ }^{\mathrm{d}}$ Chi-square $=559.350 ; \mathrm{df}=573$

${ }^{*} \mathrm{p}<.05 ;{ }^{* *} \mathrm{p}<.01$; Standard errors in parenthesis. 
Table 5. HLM Regression Estimates of Cash Transactions: Purchase Directly and Source

\section{Fixed Effects}

Intercept $^{\mathrm{a}}$

$$
\text { Direct }^{\mathrm{b}} \quad \text { Regular }^{\mathrm{C}}
$$

$\begin{array}{cc}2.689 * * & .544 * * \\ (.094) & (.048)\end{array}$

Community-Level Indicators

Poverty Level

Racial/Ethnic Heterogeneity

Female-Headed Household

Individual-Level Indicators

$\begin{array}{lcc}\text { Age } & .003 & \mathbf{- . 0 2 0 * *} \\ \text { Black } & .014) & \mathbf{( . 0 0 7 )} \\ & .078 & -.164 \\ \text { Hispanic/Latina } & (.274) & (.139) \\ & -.524 & -.598 * \\ \text { Native American } & (.443) & \mathbf{( . 2 3 7 )} \\ \text { Violent Offense } & \mathbf{- 1 . 5 1 0 *} & .159 \\ & \mathbf{( . 6 9 4 )} & (.471) \\ \text { Ever Incarcerated } & .158 & .225 \\ & (.365) & (.187) \\ \text { H.S. Education } & .436 & \mathbf{. 3 1 3} \\ & (.290) & \mathbf{( . 1 6 0 )} \\ \text { Unemployed } & -.177 & .156 \\ & (.219) & \mathbf{( . 1 1 0 )} \\ \text { Married } & .248 & .050 \\ & (.205) & (.105) \\ & .031 & .172 \\ & (.277) & (.143)\end{array}$

\section{Variance Component}

.290

.103

\footnotetext{
${ }^{\mathrm{a}}$ White arrestees represent the reference category.

${ }^{\mathrm{b}}$ Chi-square $=694.742 ; \mathrm{df}=659$

${ }^{\mathrm{c}}$ Chi-square $=702.706 ; \mathrm{df}=659$

${ }^{*} \mathrm{p}<.05 ;{ }^{*} \mathrm{p}<.01$; Standard errors in parenthesis.
} 
Table 6. HLM Regression Estimates of Cash Transaction Location Purchase

\section{Fixed Effects}

Intercept $^{\mathrm{a}}$

Community-Level Indicators

Poverty Level

.060

Racial/Ethnic Heterogeneity

(.336)

Female-Headed Household

\section{$-4.270 * *$}

(.870)
Hood $^{\mathrm{C}}$

.053

(.051)

Individual-Level Indicators

\section{$2.430 * *$}

(.589)

.182

(.290)

1.008

(.735)

Age

$-.001$

(.007)

$(.007)$

Black

$-.272 *$

$-.038$

Hispanic/Latina

(.137)

(.138)

$-.059$

.021

(.239)

(.238)

Native American

$-.225$

$-.009$

$(.442)$

(.450)

Violent Offense

.303

$-.168$

(.184)

$(.182)$

Ever Incarcerated

.172

$-.047$

(.165)

(.162)

H.S. Education

.228*

$-.147$

Unemployed

(.111)

(.110)

$-.092$

$.255^{* *}$

(.105)

Married

(.104)

$-.351 * *$

(.142)

(.182)

\section{Variance Component}

$.616 * *$

.068

\footnotetext{
${ }^{\mathrm{a}}$ White arrestees represent the reference category.

${ }^{\mathrm{b}}$ Chi-square $=823.249 ; \mathrm{df}=652$

${ }^{\mathrm{c}}$ Chi-square $=688.319 ; \mathrm{df}=644$

${ }^{*} \mathrm{p}<.05 ;{ }^{* *} \mathrm{p}<.01$; Standard errors in parenthesis.
} 


\section{Cocaine Models}

Table 1. HLM Regression Estimates of Cash and Noncash Transactions

\section{Fixed Effects}

Intercept $^{\mathrm{a}}$

\section{Cash $^{\mathrm{b}}$}

Noncash $^{\mathrm{C}}$

Community-Level Indicators

$\begin{array}{ll}.120 * & .784 * \\ (.060) & (.062)\end{array}$

Poverty Level

Racial/Ethnic Heterogeneity

Female-Headed Household

Individual-Level Indicators

Age

.004

$-.008$

Black

(.010)

(.010)

$-.349$

.224

Hispanic/Latina

(.245)

(.264)

Hispanic/Latina

$-.183$

.247

Native American

$(.232)$

(.250)

Violent Offense

$-.488$

.500

(.355)

(.392)

Ever Incarcerated

$-.253$

.500

$(.225)$

(.392)

.179

$-.083$

H.S. Education

(.199)

$(.215)$

H.S. Education

$-.139$

.020

Unemployed

(.165)

(.177)

.065

$-.003$

Married

(.159)

$(.170)$

$-.036$

$-.204$

(.194)

Variance Component

Intercept

${ }^{\mathrm{a}}$ White arrestees represent the reference category.

${ }^{\mathrm{b}}$ Chi-square $=601.252 ; \mathrm{df}=572$

${ }^{\mathrm{c}}$ Chi-square $=600.361 ; \mathrm{df}=572$

${ }^{*} \mathrm{p}<.05 ;{ }^{* *} \mathrm{p}<.01$; Standard errors in parenthesis. 
Table 2. HLM Regression Estimates of Noncash Acquisition Methods

\section{Fixed Effects}

Intercept $^{\mathrm{a}}$

$1.282 * *$

Community-Level Indicators

(.092)

Poverty Level

Racial/Ethnic Heterogeneity

Female-Headed Household

Individual-Level Indicators

Age

.006

Black

(.017)

$-.132$

(.401)

Hispanic/Latina

Native American

Native American

Violent Offense

Ever Incarcerated

H.S. Education

$-1.100 * *$

(.388)

Unemployed

(.272)

Married

\section{Variance Component}

\footnotetext{
${ }^{\mathrm{a}}$ White arrestees represent the reference category.

${ }^{\mathrm{b}}$ Chi-square $=406.397 ; \mathrm{df}=390$

${ }^{*} \mathrm{p}<.05 ;{ }^{* *} \mathrm{p}<.01$; Standard errors in parenthesis.
} 
Table 3. HLM Regression Estimates of Cash Transactions and Method of Contact

\section{Fixed Effects}

Intercept $^{\mathrm{a}}$ Apt/house ${ }^{b} \quad$ Public $^{c}$

Community-Level Indicators

$$
-1.472 * * \quad-1.685 * *
$$

(.117)

(.138)

Poverty Level

\section{Racial/Ethnic Heterogeneity}

Female-Headed Household

Individual-Level Indicators

$\begin{array}{lcc}\text { Age } & .003 & -.005 \\ \text { Black } & (.026) & (.029) \\ & .132 & .011 \\ \text { Hispanic/Latina } & (.562) & (.587) \\ & \mathbf{- 1 . 2 8 1 *} & .216 \\ \text { Native American } & \mathbf{( . 6 0 8 )} & (.638) \\ & -.432 & .935 \\ \text { Violent Offense } & (.827) & (.894) \\ & \mathbf{1 . 1 4 2 *} & -.259 \\ \text { Ever Incarcerated } & \mathbf{( . 5 2 3 )} & (.620) \\ & -.425 & .717 \\ \text { H.S. Education } & (.513) & (.593) \\ & .017 & -.772 \\ \text { Unemployed } & (.397) & (.425) \\ & -.210 & .491 \\ \text { Married } & (.387) & (.425) \\ & .388 & .367 \\ & (.461) & (.490)\end{array}$

\section{Variance Component}

.108

.914

\footnotetext{
${ }^{\mathrm{a}}$ White arrestees represent the reference category.

${ }^{\mathrm{b}}$ Chi-square $=324.199 ; \mathrm{df}=323$

${ }^{\mathrm{c}}$ Chi-square $=315.535 ; \mathrm{df}=323$

${ }^{*} \mathrm{p}<.05 ;{ }^{*} \mathrm{p}<.01$; Standard errors in parenthesis.
} 
Table 4. HLM Regression Estimates of Noncash Transactions and Method of Contact

Intercept $^{\mathrm{a}}$ Apt/house ${ }^{b} \quad$ Person $^{\mathrm{c}}$

\section{Fixed Effects}

Community-Level Indicators

$\begin{array}{ll}\mathbf{- 1 . 7 8 * *} & .137 \\ (.117) & (.075)\end{array}$

Poverty Level

Racial/Ethnic Heterogeneity

Female-Headed Household

Individual-Level Indicators

$\begin{array}{lcc}\text { Age } & .002 & .005 \\ \text { Black } & .020) & (.014) \\ & .410 & -.377 \\ \text { Hispanic/Latina } & (.474) & (.342) \\ & .075 & .046 \\ \text { Native American } & (.481) & (.347) \\ & -.571 & -.018 \\ \text { Violent Offense } & (.759) & (.485) \\ & -.301 & .602 \\ \text { Ever Incarcerated } & (.484) & (.335) \\ & -.547 & -.045 \\ \text { H.S. Education } & (.389) & (.291) \\ & -.579 & .453 \\ \text { Unemployment } & (.333) & (.244) \\ & .412 & -.031 \\ \text { Married } & (.320) & (.227) \\ & .360 & .110 \\ & (.403) & (.295)\end{array}$

\section{Variance Component}

.516

.059

\footnotetext{
${ }^{\mathrm{a}}$ White arrestees represent the reference category.

${ }^{\mathrm{b}}$ Chi-square $=381.676 ; \mathrm{df}=390$

${ }^{\mathrm{c}}$ Chi-square $=388.536 ; \mathrm{df}=390$

${ }^{*} \mathrm{p}<.05 ;{ }^{* *} \mathrm{p}<.01$; Standard errors in parenthesis.
} 
Table 5. HLM Regression Estimates of Cash Transactions: Purchase Directly and Source

\section{Fixed Effects}

Intercept $^{\mathrm{a}}$

Community-Level Indicators

Poverty Level

Racial/Ethnic Heterogeneity

Female-Headed Household

Individual-Level Indicators

$\begin{array}{lcc}\text { Age } & .010 & .012 \\ \text { Black } & (.034) & (.022) \\ & .228 & -.200 \\ \text { Hispanic } & (.751) & (.479) \\ & -.274 & -.299 \\ \text { Native American } & (.735) & (.475) \\ & 1.474 & -.115 \\ \text { Violent Offense } & (1.262) & (.689) \\ & .754 & -.139 \\ \text { Ever Incarcerated } & (.801) & (.470) \\ & -.198 & .567 \\ \text { H.S. Education } & (.737) & (.443) \\ & .530 & .411 \\ \text { Unemployed } & (.534) & (.334) \\ & .492 & .057 \\ \text { Married } & (.517) & (.325) \\ & .787 & .085 \\ \text { iance Component } & (.673) & (.398) \\ \text { rcept } & & .062 \\ \text { White arrestees represent the reference category. } & \\ \text { Chi-square = 261.193; df = 323 } & .643 & \\ \text { Ci-square = 316.968; df }=323 & & \\ .05 ; * \text { p }<.01 ; \text { Standard errors in parenthesis. } & \end{array}$

$\begin{array}{cc}\text { Direct }^{\mathrm{b}} & \text { Regular }^{\mathrm{c}} \\ \text { 2.393** } & \mathbf{8 0 9 * *} \\ \mathbf{( . 1 7 0 )} & \mathbf{( . 0 9 7 )}\end{array}$


Table 6. HLM Regression Estimates of Cash Transaction Location Purchase

\section{Fixed Effects}

Intercept $^{\mathrm{a}}$ House $^{\mathrm{b}} \quad$ Hood $^{\mathrm{c}}$

Community-Level Indicators

$\begin{array}{ll}.368 * * & -.239 * \\ (.093 & (.095)\end{array}$

Poverty Level

Racial/Ethnic Heterogeneity

Female-Headed Household

Individual-Level Indicators

$\begin{array}{lcc}\text { Age } & -.013 & .007 \\ \text { Black } & (.021) & (.020) \\ & .066 & -.178 \\ \text { Hispanic/Latina } & (.457) & (.453) \\ & -.166 & -.044 \\ \text { Native American } & (.458) & (.452) \\ & -.921 & -1.23 \\ \text { Violent Offense } & (.666) & (.700) \\ & .286 & .196 \\ \text { Ever Incarcerated } & (.456) & (.449) \\ & .324 & .706 \\ \text { H.S. Education } & (.429) & (.433) \\ & .779 * & .461 \\ \text { Unemployed } & (.321) & (.321) \\ & -.313 & .299 \\ \text { Married } & (.312) & (.307) \\ & -.367 & .277 \\ & (.375) & (.373)\end{array}$

Variance Component

.240

\footnotetext{
${ }^{\mathrm{a}}$ White arrestees represent the reference category.

${ }^{\mathrm{b}}$ Chi-square $=332.262 ; \mathrm{df}=323$

${ }^{\mathrm{c}}$ Chi-square $=342.088 ; \mathrm{df}=323$

${ }^{*} \mathrm{p}<.05 ;{ }^{* *} \mathrm{p}<.01$; Standard errors in parenthesis.
} 
D. Heroin Models

Table 1. HLM Regression Estimates of Cash and Noncash Transactions

$\begin{array}{lcc} & \text { Cash }^{\mathrm{b}} & \text { Noncash }^{\mathrm{c}} \\ & & \\ \mathbf{1 . 7 7 1} * * & -.305^{* *} \\ \mathbf{( . 1 0 1 )} & \mathbf{( . 0 7 7 )}\end{array}$

Community-Level Indicators

Poverty Level

Racial/Ethnic Heterogeneity

Female-Headed Household

Individual-Level Indicators

Age

.019

$-.015$

Black

(.017)

(.013)

Black

$-.753$

.467

Hispanic

(.474)

(.344)

.

$-.507$

$-.161$

Native American

(.550)

(.392)

.257

.980

Violent Offense

(1.098)

(.805)

Ever Incarcerated

$-.898$

$-.032$

(.538)

(.431)

$-.447$

.460

H.S. Education

(.395)

(.280)

.223

$-.167$

(.279)

Unemployed

$-.014$

(.206)

Married

Variance Component

${ }^{\mathrm{a}}$ White arrestees represent the reference category.

${ }^{\mathrm{b}}$ Chi-square $=467.363$; $\mathrm{df}=425$

${ }^{\mathrm{c}}$ Chi-square $=445.726 ; \mathrm{df}=425$

${ }^{*} \mathrm{p}<.05 ;{ }^{* *} \mathrm{p}<.01$; Standard errors in parenthesis. 
Table 2. HLM Regression Estimates of Noncash Acquisition Methods

\section{Fixed Effects}

Intercept $^{\mathrm{a}}$

$.670 * *$

(.144)

Community-Level Indicators

Poverty Level

Racial/Ethnic Heterogeneity

Female-Headed Household

Individual-Level Indicators

Age

Black

Hispanic

Native American

Violent Offense

Ever Incarcerated

1323

H.S. Education

Unemployed

Married

\section{Variance Component}

${ }^{a}$ White arrestees represent the reference category.

${ }^{\mathrm{b}}$ Chi-square $=296.645 ; \mathrm{df}=208$

${ }^{*} \mathrm{p}<.05$; ${ }^{* *} \mathrm{p}<.01$; Standard errors in parenthesis. 
Table 3. HLM Regression Estimates of Cash Transactions and Method of Contact

\section{Fixed Effects}

Intercept $^{\mathrm{a}}$ Apt/house $^{\mathrm{b}} \quad$ Public $^{\mathrm{c}}$

Community-Level Indicators

$\begin{array}{cc}-1.809 * * & -.799 * * \\ (.129) & (.123)\end{array}$

Poverty Level

$-1.652$

Racial/Ethnic Heterogeneity

(1.598)

Remale-Headed Household

$-.420$

Female-Headed Household

$(.714)$

7.986**

(2.039)

Individual-Level Indicators

$\begin{array}{lcc}\text { Age } & -.001 & -.020 \\ \text { Black } & (.023) & (.020) \\ & -.563 & .647 \\ \text { Hispanic } & (.631) & (.490) \\ & -.104 & .898 \\ \text { Native American } & (.638) & (.617) \\ \text { Violent Offense } & -1.400 & 1.830 \\ & (1.610) & (1.119) \\ \text { Ever Incarcerated } & -.168 & .683 \\ & (.813) & (.621) \\ \text { H.S. Education } & 1.013 & -.635 \\ & (.544) & (.423) \\ \text { Unemployed } & -.323 & -.050 \\ & (.362) & (.313) \\ \text { Married } & -.049 & .127 \\ & (.365) & (.313) \\ & -.139 & .372 \\ & (.468) & (.415)\end{array}$

\section{Variance Component}

Intercept

${ }^{\mathrm{b}}$ Chi-square $=323.669 ; \mathrm{df}=332$

${ }^{\mathrm{c}}$ Chi-square $=421.772 ; \mathrm{df}=329$

${ }^{*} \mathrm{p}<.05 ;{ }^{*} \mathrm{p}<.01$; Standard errors in parenthesis. 
Table 4. HLM Regression Estimates of Noncash Transactions and Method of Contact

Intercept $^{\mathrm{a}}$ Person $^{\mathrm{b}}$

\title{
Fixed Effects
}

Community-Level Indicators

Poverty Level

\section{Racial/Ethnic Heterogeneity}

Female-Headed Household

Individual-Level Indicators

$$
\text { Age }
$$

Black

Hispanic

Native American

Violent Offense

(1.489)

\author{
Violent Offense
}

Ever Incarcerated

H. S. Education

H. S. Education

Unemployed

Married

\section{Variance Component}

\footnotetext{
${ }^{\mathrm{a}}$ White arrestees represent the reference category.

${ }^{\mathrm{b}}$ Chi-square $=238.231$; $\mathrm{df}=208$

${ }^{*} \mathrm{p}<.05 ;{ }^{*} \mathrm{p}<.01$; Standard errors in parenthesis.
} 
Table 5. HLM Regression Estimates of Cash Transactions: Purchase Directly and Source

\section{Fixed Effects}

Intercept $^{\mathrm{a}}$

Direct $^{\mathrm{b}} \quad$ Regular $^{\mathrm{C}}$

Community-Level Indicators

$\begin{array}{cc}2.769 * * & 1.113^{* *} \\ (.181) & (.100)\end{array}$

Poverty Level

Racial/Ethnic Heterogeneity

Female-Headed Household

Individual-Level Indicators

$\begin{array}{lcc}\text { Age } & -.022 & .006 \\ \text { Black } & (.033) & (.019) \\ & .180 & -.724 \\ \text { Hispanic } & (.860) & (.500) \\ & .194 & -.827 \\ \text { Native American } & (.943) & (.564) \\ & -2.808 * & -.460 \\ \text { Violent Offense } & \mathbf{( 1 . 3 3 0 )} & (1.111) \\ & -.229 & -.350 \\ \text { Ever Incarcerated } & (1.074) & (.639) \\ & -.330 & .542 \\ \text { H.S. Education } & (.716) & (0.389) \\ & .148 & .088 \\ \text { Unemployed } & (.507) & (.292) \\ & .745 & .344 \\ \text { Married } & (.524) & (.296) \\ & -.222 & -.321 \\ & (.663) & (.381)\end{array}$

Variance Component

.100

\footnotetext{
${ }^{\mathrm{a}}$ White arrestees represent the reference category.

${ }^{\mathrm{b}}$ Chi-square $=360.474 ; \mathrm{df}=332$

${ }^{\mathrm{c}}$ Chi-square $=348.428$; $\mathrm{df}=332$

${ }^{*} \mathrm{p}<.05 ;{ }^{* *} \mathrm{p}<.01$; Standard errors in parenthesis.
} 
Table 6. HLM Regression Estimates of Cash Transaction Location Purchase

\begin{tabular}{|c|c|c|}
\hline & House $^{b}$ & Hood $^{\mathrm{C}}$ \\
\hline \multicolumn{3}{|l|}{ Fixed Effects } \\
\hline Intercept $^{\mathrm{a}}$ & $\begin{array}{c}-0.523^{* *} \\
(.106)\end{array}$ & $\begin{array}{l}-.194 * \\
(.097)\end{array}$ \\
\hline \multicolumn{3}{|l|}{ Community-Level Indicators } \\
\hline Poverty Level & $\begin{array}{l}\text { 2.963* } \\
(1.350)\end{array}$ & \\
\hline Racial/Ethnic Heterogeneity & $\begin{array}{c}.010 \\
(.621)\end{array}$ & \\
\hline Female-Headed Household & $\begin{array}{c}-4.913 * * \\
(1.725)\end{array}$ & \\
\hline \multicolumn{3}{|l|}{ Individual-Level Indicators } \\
\hline Age & $\begin{array}{c}.005 \\
(.018)\end{array}$ & $\begin{array}{l}.002 \\
(.016)\end{array}$ \\
\hline Black & $\begin{array}{l}.438 \\
(.486)\end{array}$ & $\begin{array}{l}-.414 \\
(.444)\end{array}$ \\
\hline Hispanic & $\begin{array}{c}.143 \\
(.507)\end{array}$ & $\begin{array}{l}-.539 \\
(.483)\end{array}$ \\
\hline Native American & $\begin{array}{l}-2.415 \\
(1.317)\end{array}$ & $\begin{array}{l}-.433 \\
(.986)\end{array}$ \\
\hline Violent Offense & $\begin{array}{l}-.558 \\
(.627)\end{array}$ & $\begin{array}{l}.606 \\
(.585)\end{array}$ \\
\hline Ever Incarcerated & $\begin{array}{l}1.120 * \\
(.432)\end{array}$ & $\begin{array}{c}.414 \\
(.355)\end{array}$ \\
\hline H.S. Education & $\begin{array}{c}.054 \\
(.288)\end{array}$ & $\begin{array}{l}-.237 \\
(.260)\end{array}$ \\
\hline Unemployed & $\begin{array}{l}-.028 \\
(.289)\end{array}$ & $\begin{array}{l}.299 \\
(.263)\end{array}$ \\
\hline Married & $\begin{array}{l}-.219 \\
(.375)\end{array}$ & $\begin{array}{l}-.473 \\
(.338)\end{array}$ \\
\hline $\begin{array}{l}\text { Variance Component } \\
\text { Intercept }\end{array}$ & .663 & $.482 *$ \\
\hline
\end{tabular}

\footnotetext{
${ }^{\mathrm{a}}$ White arrestees represent the reference category.

${ }^{\mathrm{b}}$ Chi-square $=393.100 ; \mathrm{df}=329$

${ }^{\mathrm{c}}$ Chi-square $=376.049 ; \mathrm{df}=332$

${ }^{*} \mathrm{p}<.05 ;{ }^{* *} \mathrm{p}<.01$; Standard errors in parenthesis.
} 


\section{E. Methamphetamines Models}

Table 1. HLM Regression Estimates of Cash and Noncash Transactions

\begin{tabular}{|c|c|c|}
\hline & Cash $^{b}$ & Noncash $^{\mathrm{C}}$ \\
\hline \multicolumn{3}{|l|}{ Fixed Effects } \\
\hline Intercept $^{\mathrm{a}}$ & $\begin{array}{c}.039 \\
(.049)\end{array}$ & $\begin{array}{c}1.553 * * \\
(.065)\end{array}$ \\
\hline \multicolumn{3}{|c|}{ Community-Level Indicators } \\
\hline \multicolumn{3}{|c|}{ Racial/Ethnic Heterogeneity } \\
\hline \multicolumn{3}{|c|}{ Female-Headed Household } \\
\hline \multicolumn{3}{|l|}{ Individual-Level Indicators } \\
\hline Age & $\begin{array}{l}.021 * * \\
(.008)\end{array}$ & $\begin{array}{c}-.031 * * \\
(.010)\end{array}$ \\
\hline Black & $\begin{array}{l}-.451 \\
(.258)\end{array}$ & $\begin{array}{c}.270 \\
(.344)\end{array}$ \\
\hline Hispanic & $\begin{array}{c}-.868 * * \\
(.192)\end{array}$ & $\begin{array}{l}.604 * \\
(.257)\end{array}$ \\
\hline Native American & $\begin{array}{l}.401 \\
(.407)\end{array}$ & $\begin{array}{c}.754 \\
(.570)\end{array}$ \\
\hline Violent Offense & $\begin{array}{l}-.047 \\
(.175)\end{array}$ & $\begin{array}{l}-.168 \\
(.223)\end{array}$ \\
\hline Ever Incarcerated & $\begin{array}{l}-.024 \\
(.139)\end{array}$ & $\begin{array}{c}.148 \\
(.178)\end{array}$ \\
\hline H.S. Education & $\begin{array}{c}.040 \\
(.128)\end{array}$ & $\begin{array}{l}-.028 \\
(.169)\end{array}$ \\
\hline Unemployed & $\begin{array}{l}-.019 \\
(.118)\end{array}$ & $\begin{array}{c}.135 \\
(.153)\end{array}$ \\
\hline Married & $\begin{array}{l}.306 * \\
(.147)\end{array}$ & $\begin{array}{c}-.456 * \\
(.179)\end{array}$ \\
\hline \multicolumn{3}{|l|}{ Variance Component } \\
\hline Intercept & .041 & .279 \\
\hline
\end{tabular}

${ }^{\mathrm{a}}$ White arrestees represent the reference category.

${ }^{\mathrm{b}}$ Chi-square $=598.598 ; \mathrm{df}=584$

${ }^{\mathrm{c}}$ Chi-square $=602.581 ; \mathrm{df}=584$

${ }^{*} \mathrm{p}<.05 ;{ }^{*} \mathrm{p}<.01$; Standard errors in parenthesis. 
Table 2. HLM Regression Estimates of Noncash Acquisition Methods

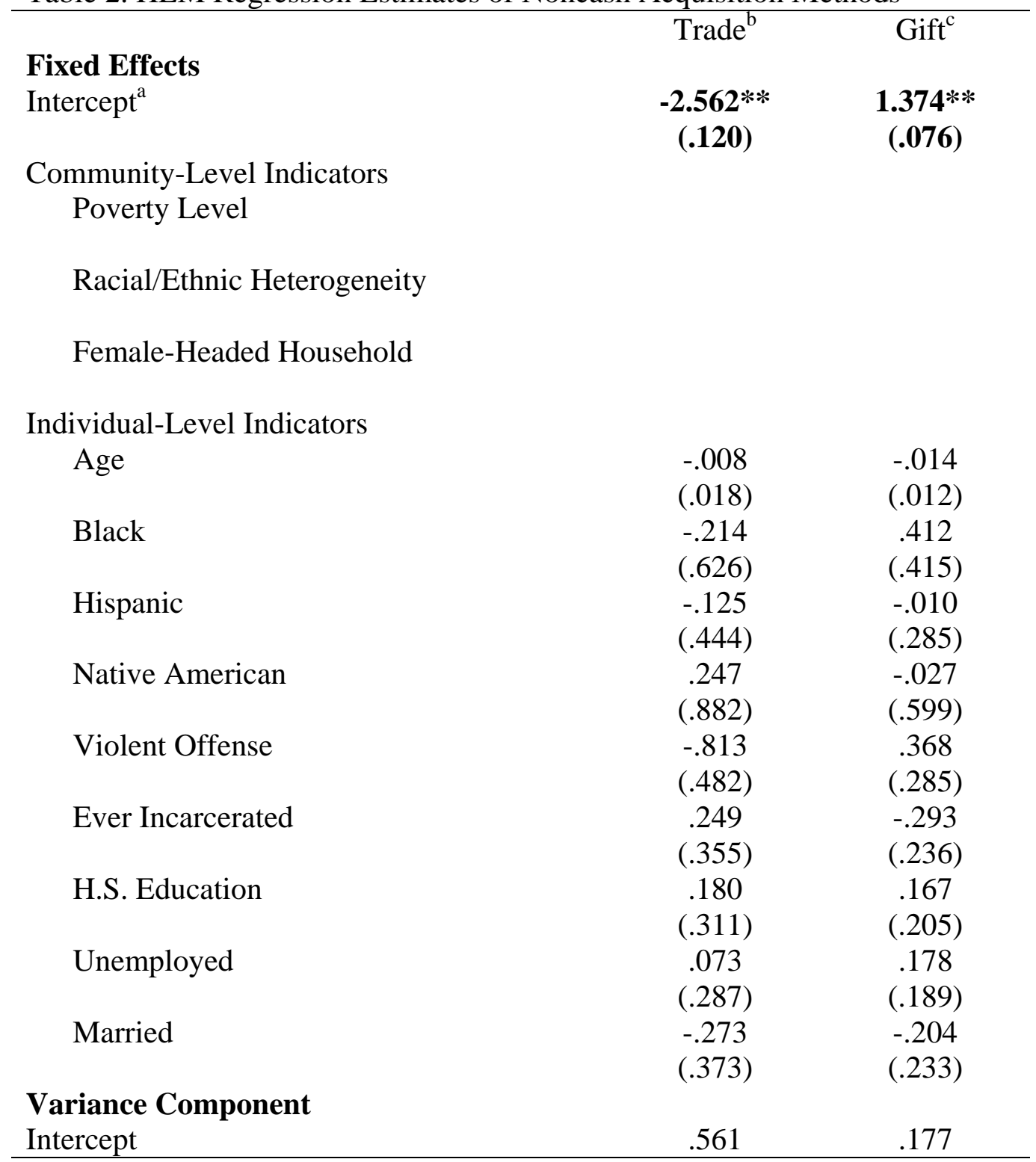

\footnotetext{
${ }^{\mathrm{a}}$ White arrestees represent the reference category.

${ }^{\mathrm{b}}$ Chi-square $=376.857 ; \mathrm{df}=484$

${ }^{\mathrm{c}}$ Chi-square $=481.838 ; \mathrm{df}=484$

${ }^{*} \mathrm{p}<.05 ;{ }^{* *} \mathrm{p}<.01$; Standard errors in parenthesis.
} 
Table 3. HLM Regression Estimates of Cash Transactions and Method of Contact

Fixed Effects

Intercept $^{\mathrm{a}}$ Apt/house ${ }^{b} \quad$ Person $^{c}$

Community-Level Indicators

$\begin{array}{cc}-1.109 * * & -2.106 * * \\ (.087) & (.125)\end{array}$

Poverty Level

Racial/Ethnic Heterogeneity

Female-Headed Household

Individual-Level Indicators

$\begin{array}{lcc}\text { Age } & -.006 & .005 \\ \text { Black } & (.016) & (.021) \\ & -.270 & .617 \\ \text { Hispanic } & (.634) & (.763) \\ & -.097 & .035 \\ \text { Native American } & (.420) & (.565) \\ & .379 & -1.067 \\ \text { Violent Offense } & (.793) & (1.253) \\ \text { Ever Incarcerated } & -.053 & -.747 \\ & (.380) & (.570) \\ \text { H.S. Education } & .028 & -.432 \\ & (.298) & (.388) \\ \text { Unemployed } & .001 & .035 \\ & (.272) & (.372) \\ \text { Married } & -.070 & .171 \\ & (.257) & (.345) \\ & .099 & -.087 \\ & (.305) & (.423)\end{array}$

Variance Component

.040

.309

\footnotetext{
${ }^{\mathrm{a}}$ White arrestees represent the reference category.

${ }^{\mathrm{b}}$ Chi-square $=371.502 ; \mathrm{df}=360$

${ }^{\mathrm{c}}$ Chi-square $=312.840 ; \mathrm{df}=360$

${ }^{*} \mathrm{p}<.05 ;{ }^{* *} \mathrm{p}<.01$; Standard errors in parenthesis.
} 
Table 4. HLM Regression Estimates of Noncash Transactions and Method of Contact

Fixed Effects

Intercept $^{\mathrm{a}}$ Apt/house $^{\mathrm{b}} \quad$ Public $^{\mathrm{c}} \quad$ Person $^{\mathrm{d}}$

Community-Level Indicators

$\begin{array}{ccc}-1.652 * * & -2.464 * * & .040 \\ (.080) & (.112) & (.061)\end{array}$

Poverty Level

Racial/Ethnic Heterogeneity

Female-Headed Household

Individual-Level Indicators

$\begin{array}{llll}\text { Age } & .004 & .029 & .001 \\ \text { Black } & (.013) & (.017) & (.010) \\ & -.038 & -.469 & -.004 \\ \text { Hispanic } & (.415) & (.632) & (.312) \\ & -.299 & .403 & .148 \\ \text { Native American } & (.316) & (.399) & (.230) \\ \text { Violent Offense } & -.812 & -.479 & .150 \\ & (.696) & (.949) & (.486) \\ \text { Ever Incarcerated } & \mathbf{. 8 1 8 * *} & -.264 & -.137 \\ & \mathbf{( . 2 7 1 )} & (.413) & (.219) \\ \text { H.S. Education } & -.009 & .266 & -.358 * \\ & (.252) & (.354) & \mathbf{( . 1 8 7}) \\ \text { Unemployed } & .168 & -.445 & .114 \\ & (.229) & (.295) & (.168) \\ \text { Married } & .061 & .220 & .003 \\ & (.207) & (.276) & (.153) \\ & -.0130 & -.069 & -.132 \\ & (.260) & (.350) & (.193)\end{array}$

\section{Variance Component}

.046

.114

\footnotetext{
${ }^{\mathrm{a}}$ White arrestees represent the reference category.

${ }^{\mathrm{b}}$ Chi-square $=458.589 ; \mathrm{df}=484$

${ }^{\mathrm{c}}$ Chi-square $=425.6 ; \mathrm{df}=484$

${ }^{\mathrm{d}}$ Chi-square $=512.609 ; \mathrm{df}=484$

${ }^{*} \mathrm{p}<.05 ;{ }^{*} \mathrm{p}<.01$; Standard errors in parenthesis.
} 
Table 5. HLM Regression Estimates of Cash Transactions: Purchase Directly and Source

Intercept $^{\mathrm{a}}$ Direct $^{\mathrm{b}} \quad$ Regular $^{\mathrm{c}}$

\section{Fixed Effects}

Community-Level Indicators

$\begin{array}{cc}2.344 * * & .345 * * \\ (.135) & (.075)\end{array}$

Poverty Level

Racial/Ethnic Heterogeneity

Female-Headed Household

Individual-Level Indicators

$\begin{array}{lcc}\text { Age } & .001 & .001 \\ & (.024) & (.014) \\ \text { Black } & .799 & .285 \\ & (1.079) & (.555) \\ \text { Hispanic } & -.105 & -.356 \\ & (.602) & (.366) \\ \text { Native American } & .989 & .242 \\ & (1.354) & (.730) \\ \text { Violent Offense } & -.216 & .258 \\ & (.542) & (.337) \\ \text { Ever Incarcerated } & .876 * & .129 \\ & \mathbf{. 4 0 8} & (.261) \\ \text { H.S. Education } & .270 & .196 \\ & (.401) & (.238) \\ \text { Unemployed } & .292 & .178 \\ & (.387) & (.226) \\ \text { Married } & .173 & -.078 \\ & (.456) & (.267)\end{array}$

\section{Variance Component}

$.088 \quad .003$

\footnotetext{
${ }^{\mathrm{a}}$ White arrestees represent the reference category.

${ }^{\mathrm{b}}$ Chi-square $=333.430 ; \mathrm{df}=360$

${ }^{\mathrm{c}}$ Chi-square $=350.437 ; \mathrm{df}=360$

${ }^{*} \mathrm{p}<.05 ;{ }^{* *} \mathrm{p}<.01$; Standard errors in parenthesis.
} 
Table 6. HLM Regression Estimates of Cash Transaction Location Purchase

\begin{tabular}{|c|c|c|}
\hline & House $^{b}$ & Hood $^{\mathrm{C}}$ \\
\hline \multicolumn{3}{|l|}{ Fixed Effects } \\
\hline Intercept $^{\mathrm{a}}$ & $\begin{array}{c}1.210 * * \\
(.089)\end{array}$ & $\begin{array}{c}-.471 * * \\
(.081)\end{array}$ \\
\hline \multicolumn{3}{|c|}{$\begin{array}{c}\text { Community-Level Indicators } \\
\text { Poverty Level }\end{array}$} \\
\hline \multicolumn{3}{|c|}{ Racial/Ethnic Heterogeneity } \\
\hline \multicolumn{3}{|c|}{ Female-Headed Household } \\
\hline \multicolumn{3}{|l|}{ Individual-Level Indicators } \\
\hline Age & $\begin{array}{l}-.022 \\
(.016)\end{array}$ & $\begin{array}{l}.020 \\
(.040)\end{array}$ \\
\hline Black & $\begin{array}{l}-.269 \\
(.630)\end{array}$ & $\begin{array}{l}-.174 \\
(.548)\end{array}$ \\
\hline Hispanic & $\begin{array}{l}-.306 \\
(.418)\end{array}$ & $\begin{array}{l}-.395 \\
(.379)\end{array}$ \\
\hline Native American & $\begin{array}{l}-.296 \\
(.840)\end{array}$ & $\begin{array}{l}-.501 \\
(.751)\end{array}$ \\
\hline Violent Offense & $\begin{array}{l}.002 \\
(.391)\end{array}$ & $\begin{array}{l}.466 \\
(.337)\end{array}$ \\
\hline Ever Incarcerated & $\begin{array}{l}.526 \\
(.299)\end{array}$ & $\begin{array}{l}-.015 \\
(.267)\end{array}$ \\
\hline H.S. Education & $\begin{array}{l}.518 \\
(.276)\end{array}$ & $\begin{array}{l}.166 \\
(.243)\end{array}$ \\
\hline Unemployed & $\begin{array}{l}.087 \\
(.264)\end{array}$ & $\begin{array}{l}.086 \\
(.230)\end{array}$ \\
\hline Married & $\begin{array}{l}.210 \\
(.315)\end{array}$ & $\begin{array}{l}-.479 \\
(.275)\end{array}$ \\
\hline $\begin{array}{l}\text { Variance Component } \\
\text { Intercept }\end{array}$ & .003 & .169 \\
\hline
\end{tabular}

\footnotetext{
${ }^{\mathrm{a}}$ White arrestees represent the reference category.

${ }^{\mathrm{b}}$ Chi-square $=332.773 ; \mathrm{df}=360$

${ }^{\mathrm{c}}$ Chi-square $=379.247 ; \mathrm{df}=360$

${ }^{*} \mathrm{p}<.05 ;{ }^{* *} \mathrm{p}<.01$; Standard errors in parenthesis.
} 
This document is a research report submitted to the U.S. Department of Justice. This report has not been published by the Department. Opinions or points of view expressed are those of the author(s) and do not necessarily reflect the official position or policies of the U.S. Department of Justice.

APPENDIX D. Male Models 


\section{A. Marijuana Models}

Table 1. HLM Regression Estimates of Cash and Noncash Transactions

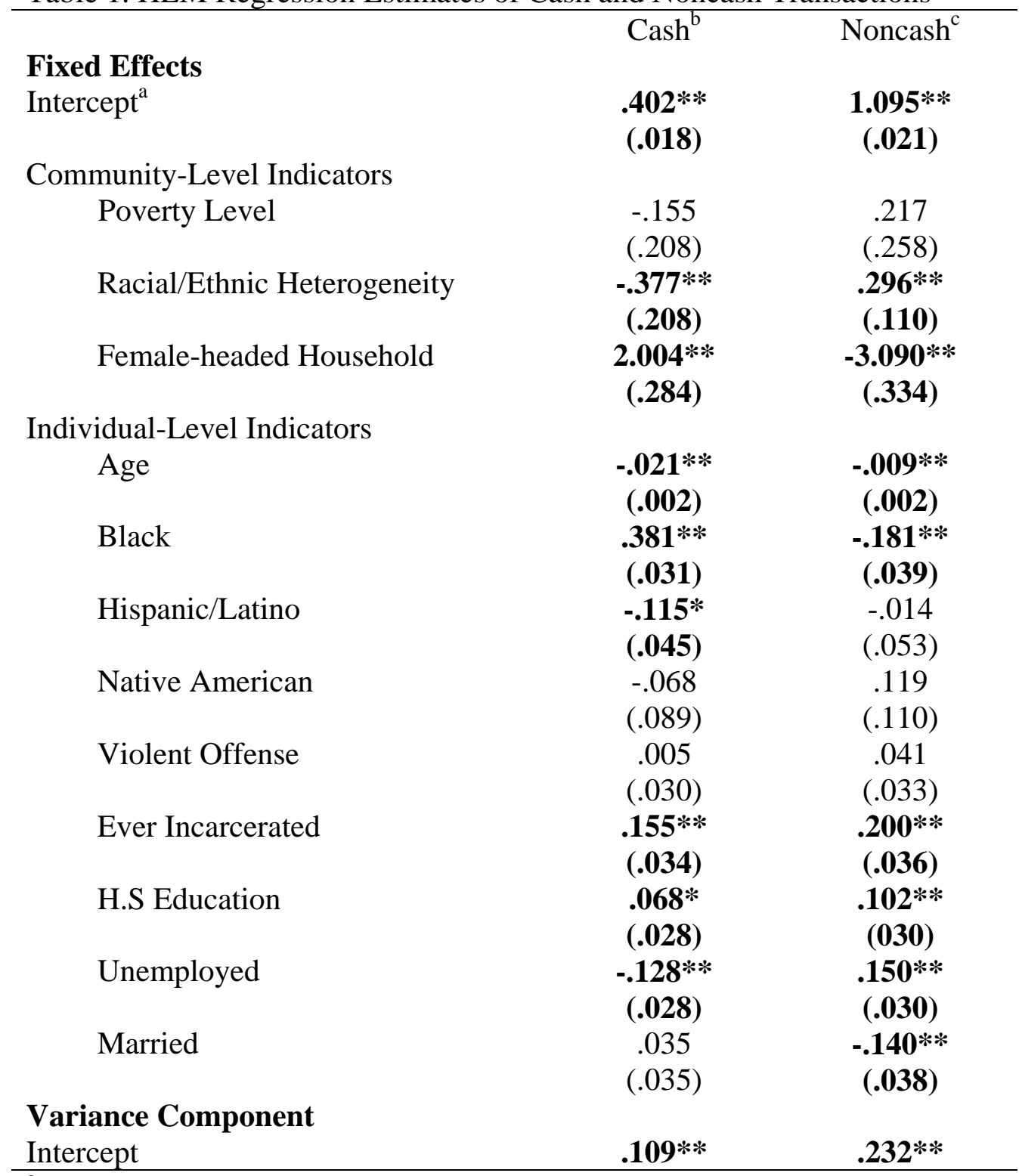

${ }^{\mathrm{a}}$ White arrestees represent the reference category.

${ }^{\mathrm{b}}$ Chi-square $=3,514.283$; $\mathrm{df}=2797$

${ }^{\mathrm{c}}$ Chi-square $=4,016.617 ; \mathrm{df}=2797$

${ }^{*} \mathrm{p}<.05 ;{ }^{* *} \mathrm{p}<.01$; Standard errors in parentheses. 
Table 2. HLM Regression Estimates of Noncash Acquisition Methods

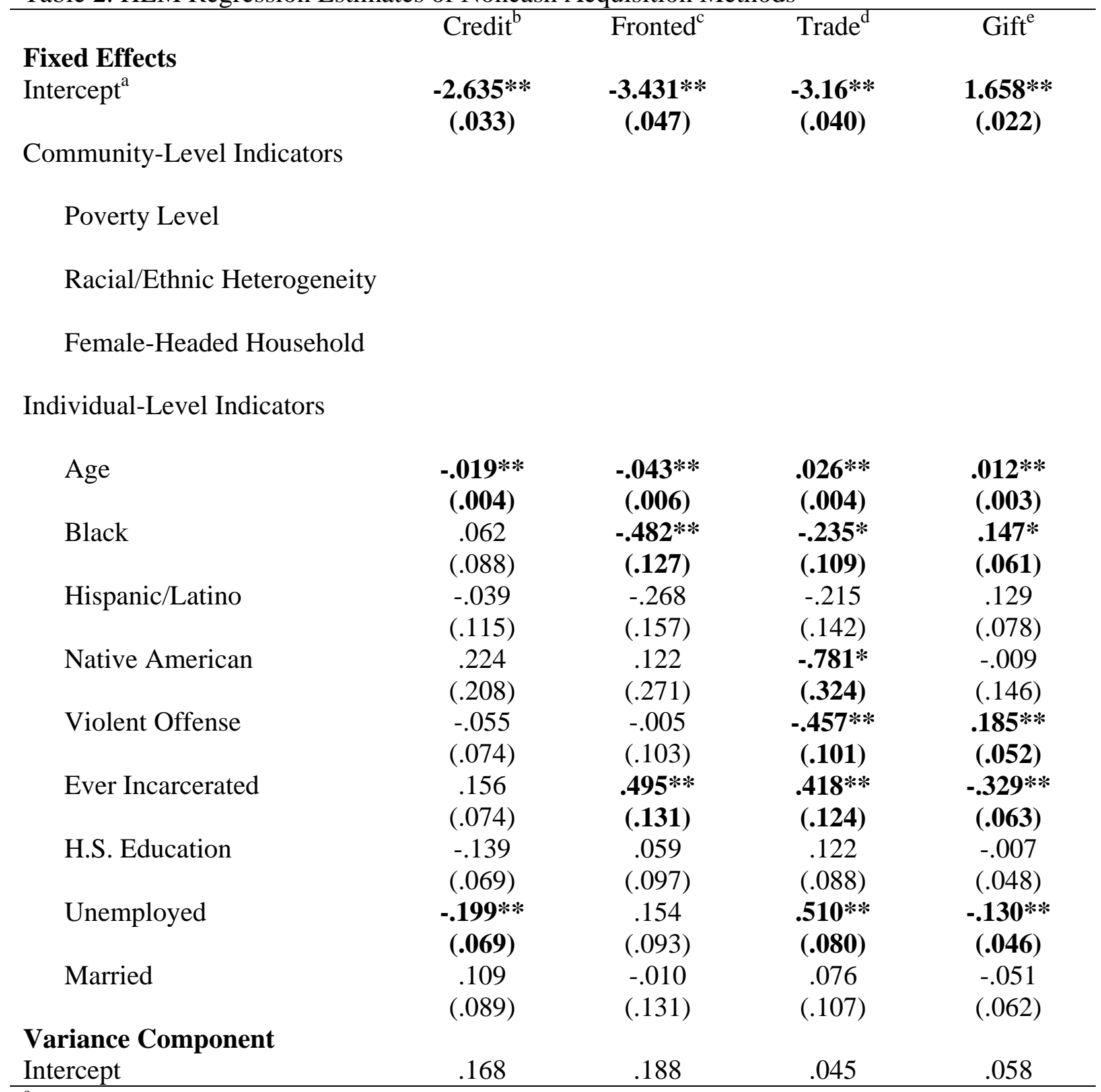

\footnotetext{
${ }^{\mathrm{a}}$ White arrestees represent the reference category.

${ }^{\mathrm{b}}$ Chi-square $=2,165.886$; $\mathrm{df}=2,329$

${ }^{c}$ Chi-square $=2,196.331 ; \mathrm{df}=2,329$

${ }^{\mathrm{d}}$ Chi-square $=2,138.635 ; \mathrm{df}=2,329$

${ }^{\mathrm{e}}$ Chi-square $=2,324.346$; $\mathrm{df}=2,329$

${ }^{*} \mathrm{p}<.05 ;{ }^{*} \mathrm{p}<.01$; Standard errors in parenthesis.
} 
Table 3. HLM Regression Estimates of Cash Transactions and Method of Contact

\begin{tabular}{|c|c|c|c|}
\hline Fixed Effects & & & \\
\hline Intercept $^{\mathrm{a}}$ & $\begin{array}{c}-1.191 * * \\
(.028)\end{array}$ & $\begin{array}{c}-1.166 * * \\
(.036)\end{array}$ & $\begin{array}{c}-2.120 * * \\
(.032)\end{array}$ \\
\hline Community-Level Indicators & & & \\
\hline Poverty Level & $.901 * *$ & $1.358 * *$ & $-.823 *$ \\
\hline & $(.334)$ & $(.420)$ & $(.397)$ \\
\hline Racial/Ethnic Heterogeneity & $-.366^{*}$ & $.603 * *$ & .083 \\
\hline & $(.145)$ & $(.185)$ & $(.168)$ \\
\hline Female-Headed Household & $-1.481 * *$ & $5.935 * *$ & $-2.946 * *$ \\
\hline & $(.028)$ & $(.036)$ & $(.507)$ \\
\hline Individual-Level Indicators & & & \\
\hline Age & -.004 & $.009 * *$ & .003 \\
\hline & $(.003)$ & $(.003)$ & $(.004)$ \\
\hline Black & -.093 & $.803 * *$ & $-.311 * *$ \\
\hline & $(.059)$ & $(.060)$ & $(.082)$ \\
\hline Hispanic/Latino & .054 & $.656 * *$ & -.224 \\
\hline & $(.080)$ & $(.084)$ & $(.114)$ \\
\hline Native American & .023 & $.573 * *$ & -.428 \\
\hline & $(.164)$ & $(.171)$ & $(.242)$ \\
\hline Violent Offense & .023 & $-.178 * *$ & -.074 \\
\hline & $(.049)$ & $(.049)$ & $(.071)$ \\
\hline Ever Incarcerated & $.308 * *$ & $-.144 *$ & -.106 \\
\hline & $(.061)$ & $(.057)$ & $(.080)$ \\
\hline H.S. Education & $-.164 * *$ & $-.218 * *$ & $.224 * *$ \\
\hline & $(.047)$ & $(.046)$ & (.069) \\
\hline Unemployed & .021 & $.178 * *$ & $-.289 * *$ \\
\hline & $(.046)$ & $(.045)$ & (.069) \\
\hline Married & $.165 * *$ & $-.140 *$ & -.002 \\
\hline & (.059) & $(.061)$ & $(.085)$ \\
\hline Variance Component & & & \\
\hline Intercept & $.281 * *$ & $.795 * *$ & .087 \\
\hline${ }^{\mathrm{a}}$ White arrestees represent the $\mathrm{r}$ & e categor & & \\
\hline${ }^{\mathrm{b}}$ Chi-square $=2,808.905 ; \mathrm{df}=2$ & & & \\
\hline${ }^{\mathrm{c}}$ Chi-square $=3,890.891 ; \mathrm{df}=2$, & & & \\
\hline${ }^{\mathrm{d}}$ Chi-square $=2,207.408 ; \mathrm{df}=2$ & & & \\
\hline${ }^{*} \mathrm{p}<.05 ;{ }^{* *} \mathrm{p}<.01 ;$ Standard error & & & \\
\hline
\end{tabular}


Table 4. HLM Regression Estimates of Noncash Transactions and Method of Contact

\begin{tabular}{|c|c|c|c|}
\hline & Apt/house ${ }^{b}$ & Public $^{c}$ & Person $^{d}$ \\
\hline \multicolumn{4}{|l|}{ Fixed Effects } \\
\hline \multirow[t]{2}{*}{ Intercept $^{\mathrm{a}}$} & $-1.700 * *$ & $-1.921 * *$ & $.053 * *$ \\
\hline & $(.027)$ & $(.033)$ & (.019) \\
\hline \multicolumn{4}{|l|}{ Community-Level Indicators } \\
\hline \multirow[t]{2}{*}{ Poverty Level } & .328 & $1.820 * *$ & -.189 \\
\hline & $(.317)$ & .342 & $(.230)$ \\
\hline \multirow[t]{2}{*}{ Racial/Ethnic Heterogeneity } & .120 & $.579 * *$ & $-.250 *$ \\
\hline & $(.140)$ & (.158) & $(.100)$ \\
\hline \multirow[t]{2}{*}{ Female-Headed Household } & $-1.382 * *$ & $3.543^{* *}$ & $-1.481 * *$ \\
\hline & $(.426)$ & $(.453)$ & (.304) \\
\hline \multicolumn{4}{|l|}{ Individual-Level Indicators } \\
\hline \multirow[t]{2}{*}{ Age } & $-.008 * *$ & .004 & $.016 * *$ \\
\hline & $(.003)$ & $(.003)$ & $(.010)$ \\
\hline \multirow[t]{2}{*}{ Black } & -.112 & $.707 * *$ & $-.200 * *$ \\
\hline & $(.062)$ & $(.063)$ & $(.045)$ \\
\hline \multirow[t]{2}{*}{ Hispanic/Latino } & .103 & $.370 * *$ & -.036 \\
\hline & $(.075)$ & $(.081)$ & $(.057)$ \\
\hline \multirow[t]{2}{*}{ Native American } & -.068 & .224 & .031 \\
\hline & $(.150)$ & $(.161)$ & $(.110)$ \\
\hline \multirow[t]{2}{*}{ Violent Offense } & .049 & $-.192 * *$ & $.076 *$ \\
\hline & $(.051)$ & $(.053)$ & $(.038)$ \\
\hline \multirow[t]{2}{*}{ Ever Incarcerated } & $.334 * *$ & $.139 *$ & $-.365 * *$ \\
\hline & $(.064)$ & $(.062)$ & $(.044)$ \\
\hline \multirow[t]{2}{*}{ H.S. Education } & -.038 & $-.337 * *$ & $.158 * *$ \\
\hline & $(.049)$ & $(.047)$ & $(.036)$ \\
\hline \multirow[t]{2}{*}{ Unemployed } & -.023 & $.250 * *$ & $-.109 * *$ \\
\hline & $(.048)$ & $(.046)$ & $(.035)$ \\
\hline \multirow[t]{2}{*}{ Married } & .091 & -.077 & -.036 \\
\hline & $(.061)$ & $(.064)$ & $(.046)$ \\
\hline \multicolumn{4}{|l|}{ Variance Component } \\
\hline Intercept & $.154 * *$ & $.289 * *$ & $.074 * *$ \\
\hline \multicolumn{4}{|c|}{${ }^{\mathrm{a}}$ White arrestees represent the reference category. } \\
\hline \multicolumn{4}{|c|}{${ }^{\mathrm{b}}$ Chi-square $=2,585.624 ; \mathrm{df}=2,326$} \\
\hline \multicolumn{4}{|c|}{${ }^{\mathrm{c}}$ Chi-square $=2,800.681 ; \mathrm{df}=2,326$} \\
\hline \multicolumn{4}{|c|}{ d Chi-square = 2,623.618; $\mathrm{df}=2,326$} \\
\hline${ }^{*} \mathrm{p}<.05 ; * * \mathrm{p}<.01 ;$ Standard errors & 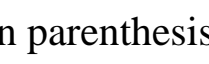 & & \\
\hline
\end{tabular}


Table 5. HLM Regression Estimates of Cash Transactions: Purchase Directly and Source

\section{Fixed Effects}

Intercept $^{\mathrm{a}}$

Community-Level Indicators

Poverty Level

Racial/Ethnic Heterogeneity

Female-Headed Household

Individual-Level Indicators

$\begin{array}{lcc}\text { Age } & \mathbf{- . 0 1 4 * *} & -.001 \\ \text { Black } & \mathbf{( . 0 0 5 )} & (.002) \\ & .070 & -\mathbf{. 1 6 9 * *} \\ \text { Hispanic/Latino } & (.118) & \mathbf{( . 0 5 0 )} \\ & .047 & -.174 * \\ \text { Native American } & (.164) & \mathbf{( . 0 6 9 )} \\ & -.380 & -.171 \\ \text { Violent Offense } & (.291) & (.138) \\ & .094 & .060 \\ \text { Ever Incarcerated } & (.101) & (.041) \\ & .247 * & .211 * * \\ \text { H.S. Education } & \mathbf{( . 1 1 1 )} & \mathbf{( . 0 4 8 )} \\ \text { Unemployed } & \mathbf{. 1 9 5 *} & -.066 \\ & \mathbf{( . 0 9 4 )} & (.039) \\ \text { Married } & .108 & .002 \\ & (.094) & (.038) \\ & -.141 & .065 \\ & (.116) & (.051)\end{array}$

Variance Component

\section{Direct $^{b} \quad$ Regular $^{c}$}

$\begin{array}{cc}3.066 * * & -.069 * * \\ (.041) & (.020)\end{array}$

.189

(.238)

$-.069$

(.102)

.035

(.299)

$-.001$

$(.002)$

$-.169 * *$

(.050)

(.069)

$-.171$

$(.041)$

211**

$-.066$

(.039)

$.038)$

$(.051)$

Intercept

.080

$.047 *$

\footnotetext{
${ }^{\mathrm{a}}$ White arrestees represent the reference category.

${ }^{\mathrm{b}}$ Chi-square $=2,120.068 ; \mathrm{df}=2,160$

${ }^{\text {c }}$ Chi-square $=2,313.697 ; \mathrm{df}=2,157$

${ }^{*} \mathrm{p}<.05 ;{ }^{* *} \mathrm{p}<.01$; Standard errors in parenthesis.
} 
Table 6. HLM Regression Estimates of Cash Transaction Location Purchase

\begin{tabular}{|c|c|c|}
\hline & House $^{b}$ & Hood $^{\mathrm{C}}$ \\
\hline \multicolumn{3}{|l|}{ Fixed Effects } \\
\hline \multirow[t]{2}{*}{ Intercept $^{\mathrm{a}}$} & $.293 * *$ & $-.445 * *$ \\
\hline & (.029) & $(.023)$ \\
\hline \multicolumn{3}{|l|}{ Community-Level Indicators } \\
\hline \multirow[t]{2}{*}{ Poverty Level } & $-.977 * *$ & $1.950 * *$ \\
\hline & $(.363)$ & $(.269)$ \\
\hline \multirow[t]{2}{*}{ Racial/Ethnic Heterogeneity } & $-.591 * *$ & $.322 * *$ \\
\hline & $(.156)$ & $(.117)$ \\
\hline \multirow[t]{2}{*}{ Female-Headed Household } & -4.554 & $1.161 * *$ \\
\hline & $(.472)$ & $(.340)$ \\
\hline \multicolumn{3}{|l|}{ Individual-Level Indicators } \\
\hline \multirow[t]{2}{*}{ Age } & -.001 & $.008 * *$ \\
\hline & $(.002)$ & $(.002)$ \\
\hline \multirow[t]{2}{*}{ Black } & $-.671 * *$ & $-.127^{\prime}$ \\
\hline & $(.052)$ & (.051) \\
\hline \multirow[t]{2}{*}{ Hispanic/Latino } & $-.379 * *$ & -.102 \\
\hline & $(.073)$ & $(.070)$ \\
\hline \multirow[t]{2}{*}{ Native American } & $-.285 *$ & -.235 \\
\hline & $(.144)$ & $(.145)$ \\
\hline \multirow[t]{2}{*}{ Violent Offense } & $.139 * *$ & .019 \\
\hline & $(.044)$ & $(.042)$ \\
\hline \multirow[t]{2}{*}{ Ever Incarcerated } & $.154 * *$ & $.372 * *$ \\
\hline & $(.052)$ & (.050) \\
\hline \multirow[t]{2}{*}{ H.S. Education } & $.167 * *$ & -.071 \\
\hline & $(.042)$ & $(.040)$ \\
\hline \multirow[t]{2}{*}{ Unemployed } & -.050 & $.172 * *$ \\
\hline & $(.041)$ & (.039) \\
\hline \multirow[t]{2}{*}{ Married } & .088 & $-.143 * *$ \\
\hline & $(.054)$ & $(.052)$ \\
\hline \multicolumn{3}{|l|}{ Variance Component } \\
\hline Intercept & $.553 * *$ & $.125 * *$ \\
\hline \multicolumn{3}{|c|}{${ }^{\mathrm{a}}$ White arrestees represent the reference category. } \\
\hline \multicolumn{3}{|c|}{${ }^{\mathrm{b}}$ Chi-square $=3,765.497 ; \mathrm{df}=2,157$} \\
\hline \multicolumn{3}{|l|}{${ }^{\mathrm{c}}$ Chi-square $=2,601.997 ; \mathrm{df}=2,157$} \\
\hline
\end{tabular}


B. Crack Models

Table 1. HLM Regression Estimates of Cash and Noncash Transactions

\begin{tabular}{|c|c|c|}
\hline & $\operatorname{Cash}^{\mathrm{b}}$ & Noncash $^{\mathrm{c}}$ \\
\hline \multicolumn{3}{|l|}{ Fixed Effects } \\
\hline \multirow[t]{2}{*}{ Intercept $^{\mathrm{a}}$} & $1.421 * *$ & $.276 * *$ \\
\hline & $(.033)$ & $(.028)$ \\
\hline \multicolumn{3}{|l|}{ Community-Level Indicators } \\
\hline \multirow[t]{2}{*}{ Poverty Level } & .374 & -.187 \\
\hline & $(.340)$ & $(.289)$ \\
\hline \multirow[t]{2}{*}{ Racial/Ethnic Heterogeneity } & -.087 & .099 \\
\hline & $(.167)$ & $(.142)$ \\
\hline \multirow[t]{2}{*}{ Female-Headed Household } & $1.567 * *$ & $-1.624 * *$ \\
\hline & $(.431)$ & (.368) \\
\hline \multicolumn{3}{|l|}{ Individual-Level Indicators } \\
\hline \multirow{2}{*}{ Age } & $.033^{* *}$ & $-.008 * *$ \\
\hline & $(.003)$ & $(.003)$ \\
\hline \multirow[t]{2}{*}{ Black } & .061 & $.126 *$ \\
\hline & $(.078)$ & $(.062)$ \\
\hline \multirow[t]{2}{*}{ Hispanic/Latino } & $-.287^{*}$ & .121 \\
\hline & (.118) & $(.099)$ \\
\hline \multirow[t]{2}{*}{ Native American } & $-.053^{*}$ & .144 \\
\hline & $(.206)$ & $(.189)$ \\
\hline \multirow[t]{2}{*}{ Violent Offense } & $-.306 * *$ & .002 \\
\hline & $(.074)$ & $(.061)$ \\
\hline \multirow[t]{2}{*}{ Ever Incarcerated } & $.410 * *$ & .146 \\
\hline & (.099) & $(.083)$ \\
\hline \multirow[t]{2}{*}{ H.S. Education } & $.139 *$ & $.193 * *$ \\
\hline & $(.065)$ & $(.051)$ \\
\hline \multirow[t]{2}{*}{ Unemployed } & .000 & $.177 * *$ \\
\hline & $(.060)$ & $(.047)$ \\
\hline \multirow[t]{2}{*}{ Married } & -.045 & -.011 \\
\hline & $(.076)$ & $(.059)$ \\
\hline \multicolumn{3}{|l|}{ Variance Component } \\
\hline Intercept & $.096 *$ & $.127 * *$ \\
\hline
\end{tabular}

${ }^{\mathrm{a}}$ White arrestees represent the reference category.

${ }^{\mathrm{b}}$ Chi-square $=1,831.167 ; \mathrm{df}=1,727$

${ }^{\mathrm{c}}$ Chi-square $=2,030.128 ; \mathrm{df}=1,727$

${ }^{*} \mathrm{p}<.05 ;{ }^{* *} \mathrm{p}<.01$; Standard errors in parenthesis. 
Table 2. HLM Regression Estimates of Noncash Acquisition Methods

\begin{tabular}{lcccc}
\hline & Credit $^{\mathrm{b}}$ & Fronted $^{\mathrm{c}}$ & Trade $^{\mathrm{d}}$ & $\mathrm{Gift}^{\mathrm{e}}$ \\
Fixed Effects & & & & \\
Intercept $^{\mathrm{a}}$ & $\mathbf{- 1 . 8 4 0 * *}$ & $\mathbf{- 2 . 6 2 6 * *}$ & $\mathbf{- 1 . 9 0 8 * *}$ & $\mathbf{. 3 9 1 * *}$ \\
& $\mathbf{( . 1 1 2 )}$ & $\mathbf{( . 0 6 2 )}$ & $\mathbf{( . 0 5 0 )}$ & $\mathbf{( . 0 3 6 )}$
\end{tabular}

Community-Level Indicators

Poverty Level

Racial/Ethnic Heterogeneity

Female-Headed Household

Individual-Level Indicators

\begin{tabular}{|c|c|c|c|c|}
\hline Age & $\begin{array}{c}.017 * * \\
(.005)\end{array}$ & $\begin{array}{l}.072 * * \\
(.007)\end{array}$ & $\begin{array}{c}.003 \\
(.006)\end{array}$ & $\begin{array}{l}.019 * * \\
(.004)\end{array}$ \\
\hline Black & $\begin{array}{l}.112 \\
(.131)\end{array}$ & $\begin{array}{l}.604^{* *} \\
(.171)\end{array}$ & $\begin{array}{c}-.475 * * \\
(.140)\end{array}$ & $\begin{array}{l}-.003 \\
(.100)\end{array}$ \\
\hline Hispanic/Latino & $\begin{array}{l}.348 \\
(.207)\end{array}$ & $\begin{array}{l}-.347 \\
(.278)\end{array}$ & $\begin{array}{c}-.545^{*} \\
(.237)\end{array}$ & $\begin{array}{c}.195 \\
(.165)\end{array}$ \\
\hline Native American & $\begin{array}{l}-.062 \\
(.373)\end{array}$ & $\begin{array}{l}.264 \\
(.423)\end{array}$ & $\begin{array}{l}-.642 \\
(.431)\end{array}$ & $\begin{array}{c}.331 \\
(.280)\end{array}$ \\
\hline Violent Offense & $\begin{array}{l}-.135 \\
(.130)\end{array}$ & $\begin{array}{c}.035 \\
(.163)\end{array}$ & $\begin{array}{c}-.407 * * \\
(.152)\end{array}$ & $\begin{array}{l}.268 * * \\
(.100)\end{array}$ \\
\hline Ever Incarcerated & $\begin{array}{l}.101 \\
(.192)\end{array}$ & $\begin{array}{l}-.151 \\
(.223)\end{array}$ & $\begin{array}{l}.325 \\
(.231)\end{array}$ & $\begin{array}{c}.067 \\
(.147)\end{array}$ \\
\hline H.S. Education & $\begin{array}{l}-.067 \\
(.110)\end{array}$ & $\begin{array}{c}.083 \\
(.141)\end{array}$ & $\begin{array}{l}.272 * \\
(.128)\end{array}$ & $\begin{array}{l}-.099 \\
(.085)\end{array}$ \\
\hline Unemployed & $\begin{array}{l}-.054 \\
(.098)\end{array}$ & $\begin{array}{c}.065 \\
(.126)\end{array}$ & $\begin{array}{l}.208 \\
(.108)\end{array}$ & $\begin{array}{l}-.081 \\
(.076)\end{array}$ \\
\hline Married & $\begin{array}{l}.015 \\
(.124)\end{array}$ & $\begin{array}{l}-.114 \\
(.170)\end{array}$ & $\begin{array}{l}.219 \\
(.137)\end{array}$ & $\begin{array}{l}-.022 \\
(.097)\end{array}$ \\
\hline $\begin{array}{l}\text { riance Component } \\
\text { ercept }\end{array}$ & .133 & .118 & .167 & $.110 * *$ \\
\hline
\end{tabular}

\footnotetext{
${ }^{\mathrm{a}}$ White arrestees represent the reference category.

${ }^{\mathrm{b}}$ Chi-square $=1,285.496 ; \mathrm{df}=1,256$

${ }^{\mathrm{c}}$ Chi-square $=1,058.718 ; \mathrm{df}=1,256$

${ }^{\mathrm{d}}$ Chi-square $=1,120.383 ; \mathrm{df}=1,164$

${ }^{\mathrm{e}}$ Chi-square $=1,274.876 ; \mathrm{df}=1,161$

${ }^{*} \mathrm{p}<.05 ;{ }^{* *} \mathrm{p}<.01$; Standard errors in parenthesis.
} 
Table 4. HLM Regression Estimates of Noncash Transactions and Method of Contact

Fixed Effects

Intercept $^{\mathrm{a}}$ Apt/house ${ }^{b} \quad$ Public $^{c} \quad$ Person $^{d}$

Community-Level Indicators

$\begin{array}{ccc}-1.459 * * & -1.263^{* *} & -.804 * * \\ (.047) & (.048) & (.035)\end{array}$

Poverty Level

Racial/Ethnic Heterogeneity

$(.525)$

(.485)

Female-Headed Household

$-.326$

$.863 * *$

(.255)

(.247)

$3.385 * *$

Individual-Level Indicators

(.630)

\begin{tabular}{|c|c|c|c|}
\hline Age & $\begin{array}{l}-.001 \\
(.005)\end{array}$ & $\begin{array}{c}-.003 \\
(.005)\end{array}$ & $\begin{array}{l}.011^{*} \\
(.005)\end{array}$ \\
\hline \multirow[t]{2}{*}{ Black } & .064 & $.704 * *$ & $-.347 * *$ \\
\hline & $(.127)$ & $(.116)$ & $(.105)$ \\
\hline \multirow[t]{2}{*}{ Hispanic/Latino } & $.444^{*}$ & .248 & -.208 \\
\hline & (.199) & (.194) & (.173) \\
\hline \multirow[t]{2}{*}{ Native American } & .484 & .373 & -.037 \\
\hline & $(.323)$ & $(.321)$ & $(.281)$ \\
\hline \multirow[t]{2}{*}{ Violent Offense } & .039 & $-.304 * *$ & $.264 *$ \\
\hline & $(.122)$ & (.113) & $(.102)$ \\
\hline \multirow[t]{2}{*}{ Ever Incarcerated } & -.078 & -.061 & -.020 \\
\hline & $(.184)$ & $(.164)$ & $(.157)$ \\
\hline \multirow[t]{2}{*}{ H.S. Education } & .176 & $-.217^{*}$ & .107 \\
\hline & (.109) & $(.093)$ & $(.090)$ \\
\hline \multirow[t]{2}{*}{ Unemployed } & -.087 & $.166 *$ & $-.231 * *$ \\
\hline & $(.096)$ & $(.084)$ & (.080) \\
\hline \multirow[t]{2}{*}{ Married } & .032 & $-.263^{*}$ & .022 \\
\hline & $(.121)$ & $(.112)$ & $(.102)$ \\
\hline
\end{tabular}

\section{Variance Component}

\footnotetext{
${ }^{\mathrm{a}}$ White arrestees represent the reference category.

${ }^{\mathrm{b}}$ Chi-square $=1,123.784 ; \mathrm{df}=1,161$

${ }^{\mathrm{c}}$ Chi-square $=1,302.547 ; \mathrm{df}=1,161$

${ }^{\mathrm{d}}$ Chi-square $=1,207.368 ; \mathrm{df}=1,164$

${ }^{*} \mathrm{p}<.05$; ${ }^{* *} \mathrm{p}<.01$; Standard errors in parenthesis.
} 
Table 5. HLM Regression Estimates of Cash Transactions: Purchase Directly and Source

\section{Fixed Effects}

Intercept $^{\mathrm{a}}$

$$
\text { Direct }^{\mathrm{b}} \quad \text { Regular }^{\mathrm{C}}
$$

$\begin{array}{cc}2.738 * * & .100 * * \\ (.056) & (.030)\end{array}$

Community-Level Indicators

Poverty Level

Racial/Ethnic Heterogeneity

Female-Headed Household

Individual-Level Indicators

$\begin{array}{lcc}\text { Age } & -.003 & \mathbf{- . 0 0 8 * *} \\ \text { Black } & (.007) & \mathbf{( . 0 0 3 )} \\ & .186 & -.220 * * \\ \text { Hispanic/Latino } & (.149) & \mathbf{( . 0 7 4 )} \\ & .144 & -.144 \\ \text { Native American } & (.252) & (.125) \\ & -.210 & -.596 * \\ \text { Violent Offense } & (.470) & \mathbf{( . 2 6 6 )} \\ & -.150 & -.028 \\ \text { Ever Incarcerated } & (.150) & (.075) \\ & .198 & .212 * \\ \text { H.S. Education } & (.208) & \mathbf{( . 1 0 5 )} \\ & .043 & -.013 \\ \text { Unemployed } & (.127) & (.061) \\ & .047 & \mathbf{. 1 5 5 * *} \\ \text { Married } & (.118) & \mathbf{( . 0 5 6 )} \\ & -.029 & -.050 \\ & (.146) & (.071)\end{array}$

\section{Variance Component}

.064

\footnotetext{
${ }^{\mathrm{a}}$ White arrestees represent the reference category.

${ }^{\mathrm{b}}$ Chi-square $=1,358.359 ; \mathrm{df}=1,475$

${ }^{\mathrm{c}}$ Chi-square $=1,560.676 ; \mathrm{df}=1,472$

${ }^{*} \mathrm{p}<.05 ;{ }^{*} \mathrm{p}<.01$; Standard errors in parenthesis.
} 
Table 6. HLM Regression Estimates of Cash Transaction Location Purchase

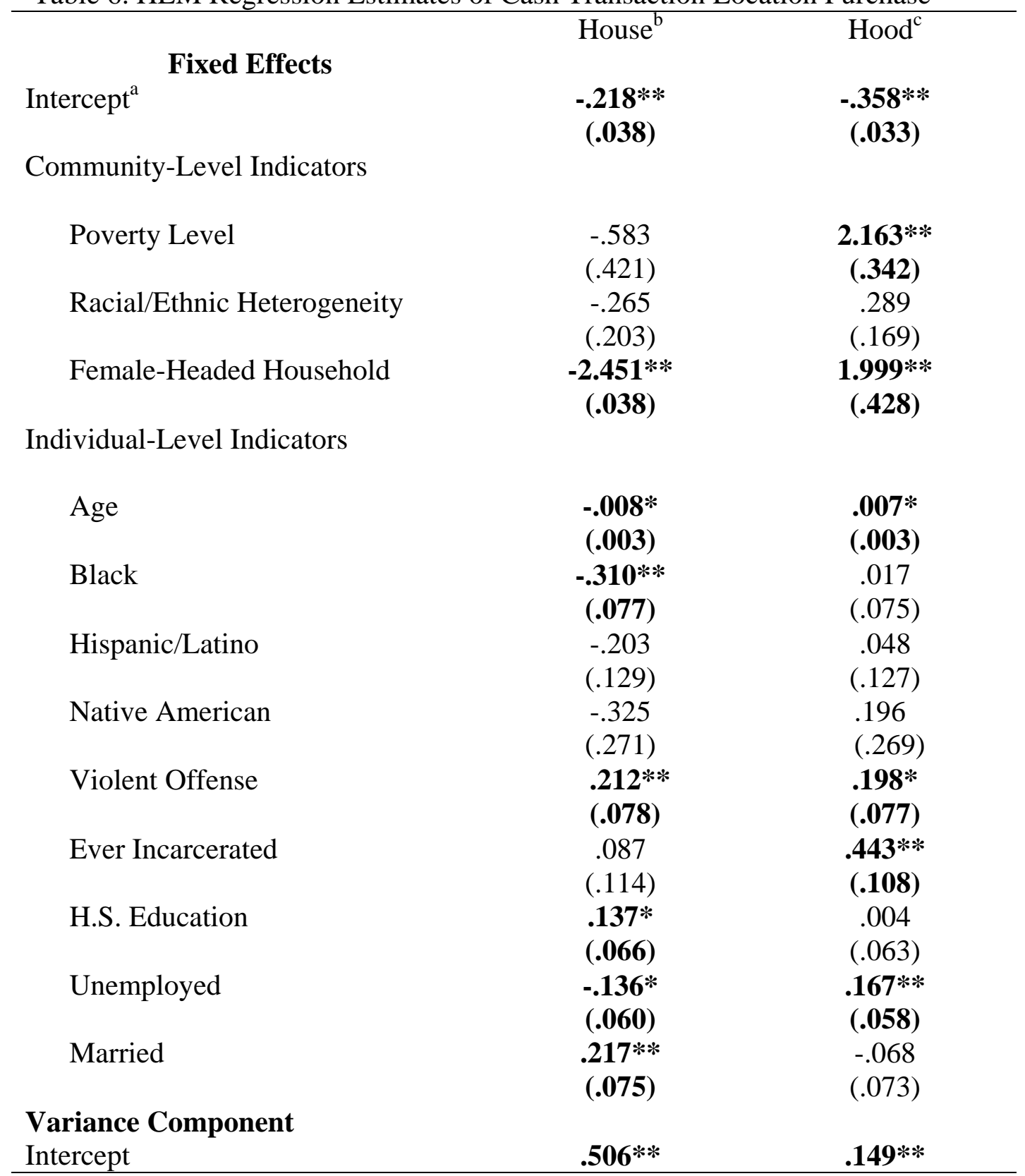

${ }^{\mathrm{a}}$ White arrestees represent the reference category.

${ }^{\mathrm{b}}$ Chi-square $=2,199.047$; $\mathrm{df}=1,472$

${ }^{\mathrm{c}}$ Chi-square $=1,650.180 ; \mathrm{df}=1,472$

${ }^{*} \mathrm{p}<.05 ;{ }^{* *} \mathrm{p}<.01$; Standard errors in parenthesis. 


\section{Cocaine Models}

Table 1. HLM Regression Estimates of Cash and Noncash Transactions

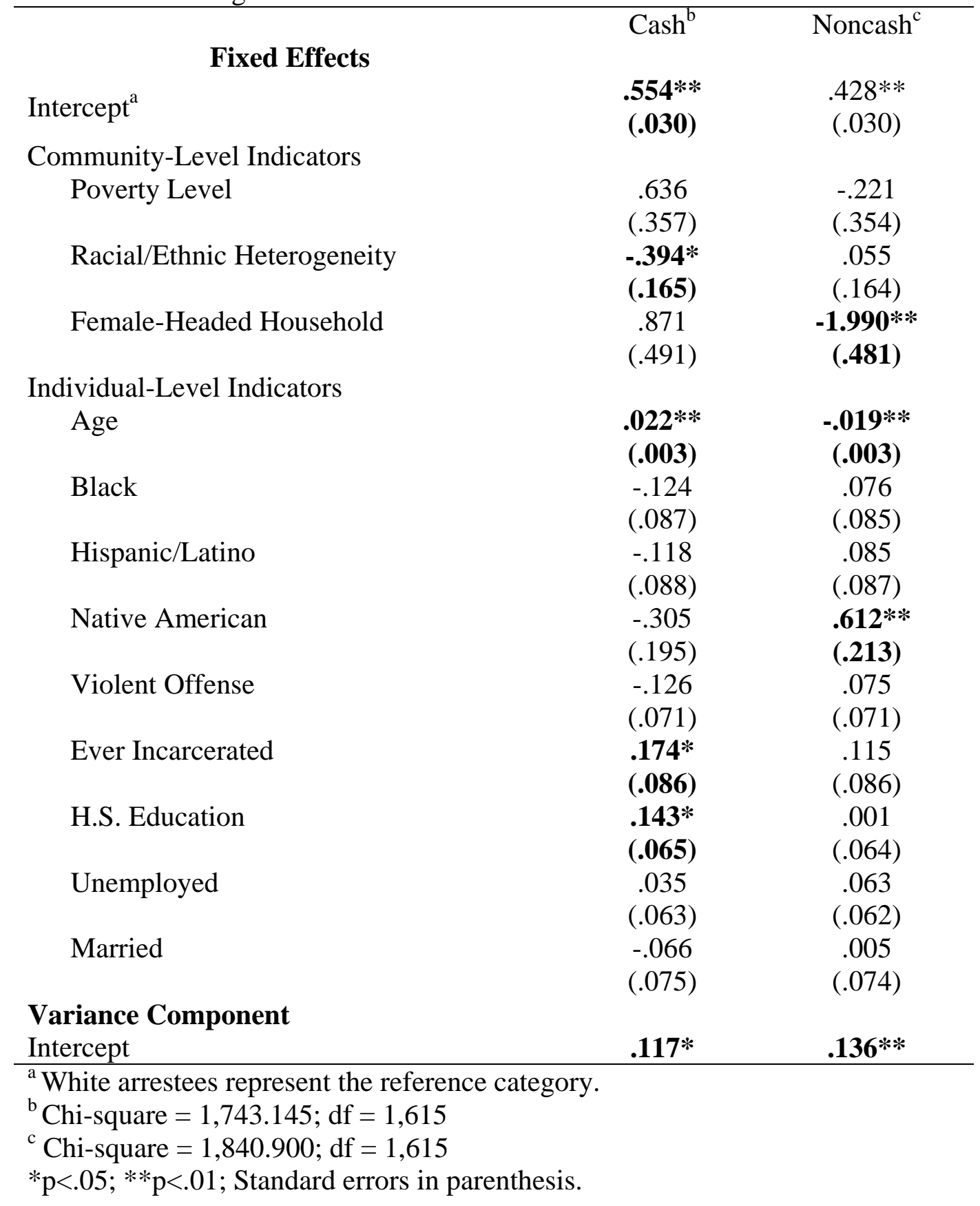


Table 2. HLM Regression Estimates of Noncash Acquisition Methods

Credit $^{\mathrm{b}} \quad$ Fronted $^{\mathrm{c}} \quad$ Trade $^{\mathrm{d}} \quad$ Gift $^{\mathrm{e}}$

\section{Fixed Effects}

Intercept $^{\mathrm{a}}$

$\begin{array}{cccc}-2.352 * * & -2.876 * * & -2.513 * * & 1.094 * * \\ (.062 & (.081) & (.069) & (.041)\end{array}$

Community-Level Indicators

Poverty Level

Racial/Ethnic Heterogeneity

Female-Headed Household

Individual-Level Indicators

Age

$\begin{array}{cccc}.007 & -.035 * * & \mathbf{. 0 3 0} * * & -.004 \\ (.009) & \mathbf{( . 0 1 1 )} & \mathbf{( . 0 0 9 )} & (.006) \\ .394 & .492 & -.073 & -.280 \\ (.225) & (.269) & (.233) & (.147) \\ .255 & -.184 & -.222 & .047 \\ (.219) & (.272) & (.228) & (.143) \\ \mathbf{. 8 7 9} & -.671 & -1.069 & .148 \\ \mathbf{( . 3 7 7 )} & (.652) & (.584) & (.299) \\ -.293 & .118 & .002 & .129 \\ (.187) & (.221) & (.192) & (.120) \\ .299 & .518 & \mathbf{. 7 2 8} * & -.531 * * \\ (.238) & (.303) & \mathbf{( . 2 8 0 )} & \mathbf{( . 1 5 9 )} \\ -.153 & -.039 & .147 & -.006 \\ (.163) & (.202) & (.176) & (.108) \\ -.136 & .254 & \mathbf{. 5 0 6 * *} & -.245 * \\ (.160) & (.191) & \mathbf{( . 1 6 1 )} & \mathbf{( . 1 0 3 )} \\ .049 & -.228 & -.161 & .080 \\ (.189) & (.249) & (.205) & (.127)\end{array}$

\section{Variance Component}

$\begin{array}{llll}.039 & .299 & .137 & .052\end{array}$

\footnotetext{
${ }^{\mathrm{a}}$ White arrestees represent the reference category.

${ }^{\mathrm{b}}$ Chi-square $=1,089.938 ; \mathrm{df}=1,173$

${ }^{\mathrm{c}}$ Chi-square $=1,076.994 ; \mathrm{df}=1,173$

${ }^{\mathrm{d}}$ Chi-square $=1,173.110 ; \mathrm{df}=1,173$

${ }^{\text {e }}$ Chi-square $=1,206.884 ; \mathrm{df}=1,173$

${ }^{*} \mathrm{p}<.05 ;{ }^{*} \mathrm{p}<.01$; Standard errors in parenthesis.
} 
Table 3. HLM Regression Estimates of Cash Transactions and Method of Contact

\begin{tabular}{|c|c|c|c|}
\hline & Apt/house $^{b}$ & Public $^{\mathrm{c}}$ & Person $^{\mathrm{d}}$ \\
\hline \multicolumn{4}{|l|}{ Fixed Effects } \\
\hline Intercept $^{\mathrm{a}}$ & $\begin{array}{c}-1.470 * * \\
(.052)\end{array}$ & $\begin{array}{c}-1.371 * * \\
(.057)\end{array}$ & $\begin{array}{c}-2.572 * * \\
(.066)\end{array}$ \\
\hline \multicolumn{4}{|l|}{ Community-Level Indicators } \\
\hline Poverty Level & $\begin{array}{c}2.182 * * \\
(.562)\end{array}$ & $\begin{array}{c}1.352 * \\
(.623)\end{array}$ & \\
\hline Racial/Ethnic & $-.685^{*}$ & .506 & \\
\hline \multirow{2}{*}{$\begin{array}{l}\text { Heterogeneity } \\
\text { Female-Headed Household }\end{array}$} & $(.280)$ & $(.307)$ & \\
\hline & $\begin{array}{l}-1.216 \\
(.761)\end{array}$ & $\begin{array}{c}4.694 * * \\
(.818)\end{array}$ & \\
\hline \multicolumn{4}{|l|}{ Individual-Level Indicators } \\
\hline Age & $\begin{array}{c}.006 \\
(.006)\end{array}$ & $\begin{array}{c}.007 \\
(.006)\end{array}$ & $\begin{array}{l}-.017 \\
(.009)\end{array}$ \\
\hline Black & $\begin{array}{l}.196 \\
(.155)\end{array}$ & $\begin{array}{l}.513 * * \\
(.150)\end{array}$ & $\begin{array}{l}-.303 \\
(.237)\end{array}$ \\
\hline Hispanic/Latino & $\begin{array}{c}.176 \\
(.156)\end{array}$ & $\begin{array}{l}.635 * * \\
(.165)\end{array}$ & $\begin{array}{l}.466 * \\
(.232)\end{array}$ \\
\hline Native American & $\begin{array}{l}.106 \\
(.364)\end{array}$ & $\begin{array}{l}-.152 \\
(.431)\end{array}$ & $\begin{array}{c}1.347 * * \\
(.409)\end{array}$ \\
\hline Violent Offense & $\begin{array}{l}.205 \\
(.125)\end{array}$ & $\begin{array}{l}-.068 \\
(.132)\end{array}$ & $\begin{array}{l}-.058 \\
(.197)\end{array}$ \\
\hline Ever Incarcerated & $\begin{array}{l}.469 * * \\
(.171)\end{array}$ & $\begin{array}{c}-.485 * * \\
(.157)\end{array}$ & $\begin{array}{c}-.654 * * \\
(.216)\end{array}$ \\
\hline H.S. Education & $\begin{array}{l}.020 \\
(.113)\end{array}$ & $\begin{array}{l}-.184 \\
(.113)\end{array}$ & $\begin{array}{c}.284 \\
(.176)\end{array}$ \\
\hline Unemployed & $\begin{array}{c}.036 \\
(.109)\end{array}$ & $\begin{array}{c}.006 \\
(.109)\end{array}$ & $\begin{array}{l}-.175 \\
(.170)\end{array}$ \\
\hline Married & $\begin{array}{l}-.063 \\
(.128)\end{array}$ & $\begin{array}{c}.081 \\
(.131)\end{array}$ & $\begin{array}{l}-.022 \\
(.198)\end{array}$ \\
\hline \multicolumn{4}{|l|}{ Variance Component } \\
\hline Intercept & $.408^{*}$ & $.814 * *$ & .061 \\
\hline $\begin{array}{l}{ }^{\mathrm{a}} \text { White arrestees represent the } \mathrm{r} \\
{ }^{\mathrm{b}} \text { Chi-square }=1,314.605 ; \mathrm{df}= \\
{ }^{\mathrm{c}} \text { Chi-square }=1,592.556 ; \mathrm{df}= \\
{ }^{\mathrm{d}} \text { Chi-square }=1,227.517 ; \mathrm{df}= \\
{ }^{*} \mathrm{p}<.05 ;{ }^{* *} \mathrm{p}<.01 ; \text { Standard erro }\end{array}$ & $\begin{array}{l}27 \\
27 \\
30\end{array}$ & & \\
\hline
\end{tabular}


Table 4. HLM Regression Estimates of Non-cash Transactions and Method of Contact

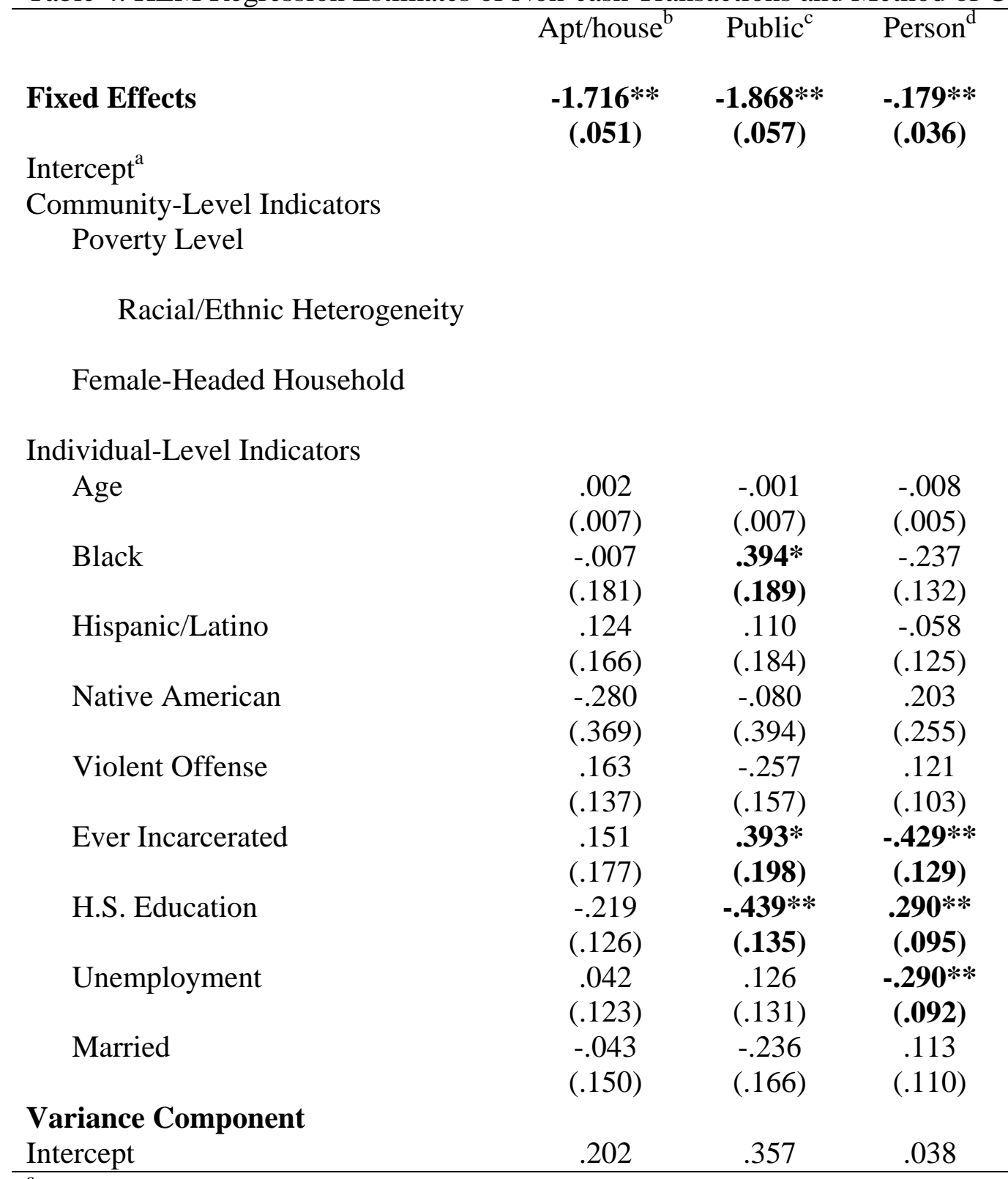

\footnotetext{
${ }^{\mathrm{a}}$ White arrestees represent the reference category.

${ }^{\mathrm{b}}$ Chi-square $=1,135.735 ; \mathrm{df}=1,173$

${ }^{\text {c }}$ Chi-square $=1,214.251 ; \mathrm{df}=1,173$

${ }^{\mathrm{d}}$ Chi-square $=1,185.094 ; \mathrm{df}=1,173$

${ }^{*} \mathrm{p}<.05 ;{ }^{* *} \mathrm{p}<.01$; Standard errors in parenthesis.
} 
Table 5. HLM Regression Estimates of Cash Transactions: Purchase Directly and Source

Fixed Effects

Intercept $^{\mathrm{a}}$

Direct ${ }^{b}$ Regular $^{c}$

$\begin{array}{ll}2.66 * * & .458 * * \\ (.067) & (.034)\end{array}$

Community-Level Indicators

Poverty Level

Racial/Ethnic Heterogeneity

Female-Headed Household

Individual-Level Indicators

$\begin{array}{lcc}\text { Age } & -.012 & \mathbf{. 0 1 1} \\ \text { Black } & (.009) & \mathbf{( . 0 0 5 )} \\ & -.157 & -.086 \\ \text { Hispanic/Latino } & (.238) & (.124) \\ & .129 & -.274^{*} \\ \text { Native American } & (.255) & \mathbf{( . 1 2 9 )} \\ & .432 & -.237 \\ \text { Violent Offense } & (.649) & (.296) \\ \text { Ever Incarcerated } & -.501 * & -.025 \\ & \mathbf{( . 1 9 2 )} & (.105) \\ \text { H.S. Education } & .321 & . \mathbf{2 9 1} \\ & (.247) & \mathbf{( . 1 3 2 )} \\ \text { Unemployed } & -.041 & -.087 \\ & (.183) & (.094) \\ \text { Married } & .103 & \mathbf{. 2 8 4} * \\ & (.176) & \mathbf{( . 0 9 0 )} \\ & .287 & -.029 \\ & (.214) & (.106)\end{array}$

\section{Variance Component}

.004

.001

\footnotetext{
${ }^{\mathrm{a}}$ White arrestees represent the reference category.

${ }^{\mathrm{b}}$ Chi-square $=1,133.242 ; \mathrm{df}=1,230$

${ }^{\mathrm{c}}$ Chi-square $=1,179.667 ; \mathrm{df}=1,230$

${ }^{*} \mathrm{p}<.05 ;{ }^{* *} \mathrm{p}<.01$; Standard errors in parenthesis.
} 
Table 6. HLM Regression Estimates of Cash Transaction Location Purchase

\section{Fixed Effects}

Intercept $^{\mathrm{a}}$

Community-Level Indicators

Poverty Level

Racial/Ethnic Heterogeneity

Female-Headed Household

Individual-Level Indicators

$$
\text { Age }
$$

Black

Hispanic/Latino

Native American

Violent Offense

Ever Incarcerated

H.S. Education

Unemployed

Married

\section{Variance Component}

Intercept

\footnotetext{
${ }^{\mathrm{a}}$ White arrestees represent the reference category.

${ }^{\mathrm{b}}$ Chi-square $=1,510.427 ; \mathrm{df}=1,227$

${ }^{\text {c }}$ Chi-square $=1,297.967 ; \mathrm{df}=1,230$

${ }^{*} \mathrm{p}<.05 ;{ }^{*} \mathrm{p}<.01$; Standard errors in parenthesis.
}

House $^{\mathrm{b}} \quad$ Hood $^{\mathrm{C}}$

$\begin{array}{lc}.040 & -343 * * \\ (.042) & (.036)\end{array}$

.087

$(.491)$

$-.701 * *$

(.235)

$-3.023 * *$

(.658)

$-.011 *$

.010 *

(.005)

(.005)

-.006

-.068

(.124)

(.122)

$-.101$

$-.091$

(.129)

(.128)

$-.187$

$-.093$

(.295)

.120

$(.295)$

(.105)

$.447 * *$

$-.094$

(.105)

$.507 * *$

(.134)

(.137)

.041

$-.090$

(.093)

(.092)

$-.048$

.230*

(.090)

(.088)

.080

$-.164$

(.106)

(.106)

$.365^{* *}$ 
D. Heroin Models

Table 1. HLM Regression Estimates of Cash and Noncash Transactions

\section{Fixed Effects}

Intercept $^{\mathrm{a}}$

Community-Level Indicators

Cash $^{\mathrm{b}} \quad$ Noncash $^{\mathrm{c}}$

Poverty Level

1.787**

(.051)

$-.102 *$

(.041)

.201

Racial/Ethnic Heterogeneity

Female-Headed Household

dividual-Level Indicators

$-2.333^{* *}$

(.577)

Age

$.017 * *$

$-.013 * *$

Black

(.006)

(.005)

$-.291$

.246

(.187)

Hispanic/Latino

$-.128$

(.134)

Native American

(.190)

.156

.901

(.136)

Violent Offense

(.621)

$-.090$

(.370)

$-.245$

$-.048$

Ever Incarcerated

(.169)

(.127)

$-.178$

$.551^{* *}$

(.213)

H.S. Education

.117

(.127)

(.126)

.109

Unemployed

Married

\section{Variance Component}

${ }^{\mathrm{a}}$ White arrestees represent the reference category.

${ }^{\mathrm{b}}$ Chi-square $=1,096.706 ; \mathrm{df}=1,095$

${ }^{\mathrm{c}}$ Chi-square $=1,209.818 ; \mathrm{df}=1,092$

${ }^{*} \mathrm{p}<.05 ;{ }^{* *} \mathrm{p}<.01$; Standard errors in parenthesis. 
Table 2. HLM Regression Estimates of Noncash Acquisition Methods

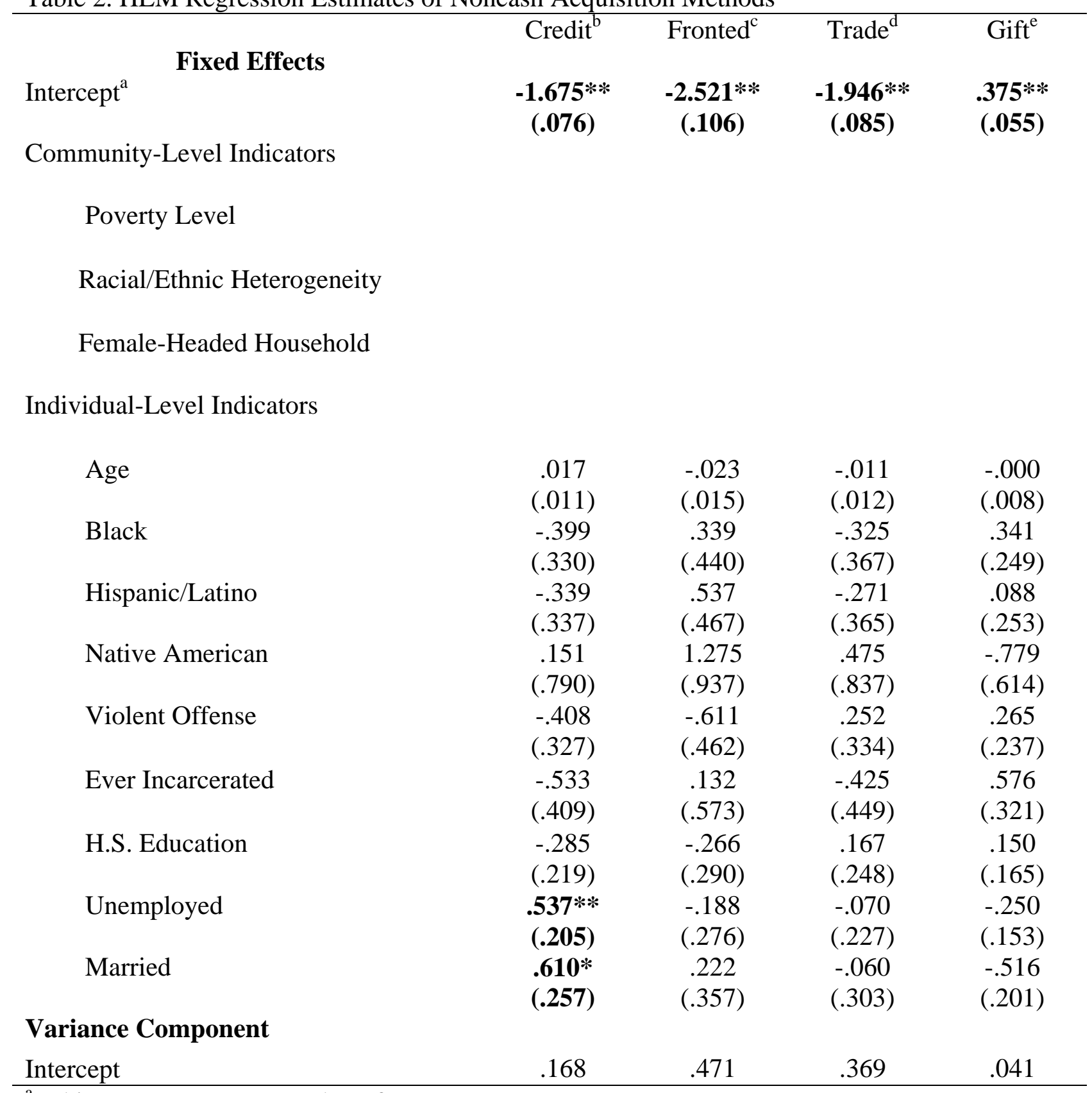

${ }^{\mathrm{a}}$ White arrestees represent the reference category

${ }^{\mathrm{b}}$ Chi-square $=649.172 ; \mathrm{df}=675$

${ }^{\mathrm{c}}$ Chi-square $=521.427 ; \mathrm{df}=675$

${ }^{\mathrm{d}}$ Chi-square $=643.153 ; \mathrm{df}=675$

${ }^{\mathrm{e}}$ Chi-square $=699.278 ; \mathrm{df}=675$

${ }^{*} \mathrm{p}<.05 ;{ }^{*} \mathrm{p}<.01$; Standard errors in parenthesis 
Table 3. HLM Regression Estimates of Cash Transactions and Method of Contact

\section{Fixed Effects \\ Fixed Effects}

Intercept $^{\mathrm{a}}$

Apt/house ${ }^{b} \quad$ Public $^{c} \quad$ Person $^{d}$

(ntercept

$\begin{array}{ccc}-1.728 * * & -.686 * * & -3.568 * * \\ (.063) & (.064) & (.121)\end{array}$

Community-Level Indicators

Poverty Level

Racial/Ethnic Heterogeneity

Female-Headed Household

Individual-Level Indicators

$\begin{array}{lccc}\text { Age } & -.010 & \mathbf{. 0 1 4} & .003 \\ \text { Black } & (.008) & \mathbf{( . 0 0 6 )} & (.016) \\ & -.005 & \mathbf{. 5 9 6 * *} & .227 \\ \text { Hispanic/Latino } & (222) & \mathbf{( . 1 7 9 )} & (.485) \\ & .023 & \mathbf{. 4 6 3} & .527 \\ \text { Native American } & (.216) & \mathbf{( . 1 9 0 )} & (.464) \\ & -.340 & .550 & \mathbf{2 . 4 3 5 *} \\ \text { Violent Offense } & (.610) & (.510) & \mathbf{( . 7 0 1 )} \\ & .233 & .047 & .036 \\ \text { Ever Incarcerated } & (.198) & (.178) & (.442) \\ & .028 & -.258 & .461 \\ \text { H.S. Education } & (.242) & (.200) & (.576) \\ & .229 & -.084 & -.258 \\ \text { Unemployed } & (.147) & (.123) & (.305) \\ & -.235 & .167 & -.389 \\ \text { Married } & (.134) & (.112) & (.290) \\ & .164 & -.240 & -.308 \\ \text { iance Component } & (.163) & (.141) & (.442) \\ \text { rept } & & & \\ \end{array}$

.733

$(.753)$

$-536$

(.350)

4.872**

(.932)

\section{Variance Component}

Intercept

${ }^{\mathrm{b}}$ Chi-square $=972.484 ; \mathrm{df}=939$

${ }^{\text {c }}$ Chi-square $=1,468.225 ; \mathrm{df}=936$

${ }^{\mathrm{d}}$ Chi-square $=826.306 ; \mathrm{df}=939$

${ }^{*} \mathrm{p}<.05 ;{ }^{* *} \mathrm{p}<.01$; Standard errors in parenthesis. 
Table 4. HLM Regression Estimates of Noncash Transactions and Method of Contact

Fixed Effects

Intercept $^{\mathrm{a}}$ Apt/house ${ }^{b} \quad$ Public $^{c} \quad$ Person $^{\mathrm{d}}$

Community-Level Indicators

$\begin{array}{ccc}-1.710 * * & -1.478 * * & -1.041^{* *} \\ (.076) & (.084) & (.060)\end{array}$

Poverty Level

2.009*

(882)

Racial/Ethnic Heterogeneity

$-.324$

Female-Headed Household

$(.425)$

$3.454 * *$

(1.114)

Individual-Level Indicators

\begin{tabular}{|c|c|c|c|}
\hline Age & $\begin{array}{c}-.007 \\
(.011)\end{array}$ & $\begin{array}{l}.019 * \\
(.010)\end{array}$ & $\begin{array}{l}-.005 \\
(.009)\end{array}$ \\
\hline \multirow[t]{2}{*}{ Black } & -.073 & $.640 *$ & .070 \\
\hline & (.336) & $(.425)$ & $(.273)$ \\
\hline \multirow[t]{2}{*}{ Hispanic/Latino } & .410 & -.259 & -.287 \\
\hline & (.334) & $(.318)$ & $(.284)$ \\
\hline \multirow[t]{2}{*}{ Native American } & -1.020 & .571 & .073 \\
\hline & (.979) & $(.753)$ & $(.670)$ \\
\hline \multirow[t]{2}{*}{ Violent Offense } & .316 & .211 & .218 \\
\hline & $(.303)$ & $(.281)$ & $(.257)$ \\
\hline \multirow[t]{2}{*}{ Ever Incarcerated } & .141 & .093 & .543 \\
\hline & (.439) & $(.373)$ & $(.383)$ \\
\hline \multirow[t]{2}{*}{ H. S. Education } & $.699 * *$ & $-.417^{*}$ & -.264 \\
\hline & $(.235)$ & (.193) & $(.182)$ \\
\hline \multirow[t]{2}{*}{ Unemployed } & -.013 & .129 & $-.389 *$ \\
\hline & $(.208)$ & $(.182)$ & (.171) \\
\hline \multirow[t]{2}{*}{ Married } & .297 & -.325 & $-.495^{*}$ \\
\hline & $(.263)$ & $(.246)$ & (.233) \\
\hline \multicolumn{4}{|l|}{ ance Component } \\
\hline cept & .136 & .595 & .017 \\
\hline \multicolumn{4}{|c|}{$\begin{array}{l}\text { ite arrestees represent the reference category. } \\
\text {-square }=649.467 ; \mathrm{df}=675\end{array}$} \\
\hline
\end{tabular}


Table 5. HLM Regression Estimates of Cash Transactions: Purchase Directly and Source

Fixed Effects

Intercept $^{\mathrm{a}}$

Community-Level Indicators

Poverty Level

Racial/Ethnic Heterogeneity

Female-Headed Household

Individual-Level Indicators

\begin{tabular}{|c|c|c|}
\hline Age & $\begin{array}{c}.017 \\
(.013)\end{array}$ & $\begin{array}{l}-.005 \\
(.006)\end{array}$ \\
\hline Black & $\begin{array}{l}-.481 \\
(.357)\end{array}$ & $\begin{array}{l}-.212 \\
(.170)\end{array}$ \\
\hline Hispanic/Latino & $\begin{array}{c}.058 \\
(.366)\end{array}$ & $\begin{array}{l}-.089 \\
(.172)\end{array}$ \\
\hline Native American & $\begin{array}{l}-.511 \\
(.857)\end{array}$ & $\begin{array}{l}-.620 \\
(.444)\end{array}$ \\
\hline Violent Offense & $\begin{array}{l}-.153 \\
(.330)\end{array}$ & $\begin{array}{l}-.145 \\
(.161)\end{array}$ \\
\hline Ever Incarcerated & $\begin{array}{l}-.042 \\
(.401)\end{array}$ & $\begin{array}{l}.304 \\
(.181)\end{array}$ \\
\hline H.S. Education & $\begin{array}{l}-.262 \\
(.241)\end{array}$ & $\begin{array}{l}-.004 \\
(.112)\end{array}$ \\
\hline Unemployed & $\begin{array}{l}.163 \\
(.218)\end{array}$ & $\begin{array}{l}.267 * \\
(.103)\end{array}$ \\
\hline Married & $\begin{array}{c}.077 \\
(.276)\end{array}$ & $\begin{array}{l}-.168 \\
(.127)\end{array}$ \\
\hline $\begin{array}{l}\text { ance Component } \\
\text { cept }\end{array}$ & .168 & .002 \\
\hline
\end{tabular}

$\begin{array}{cc}2.938 * * & .785 * * \\ (.090) & (.041)\end{array}$


Table 6. HLM Regression Estimates of Cash Transaction Location Purchase

\begin{tabular}{|c|c|c|}
\hline & House $^{b}$ & Hood $^{\mathrm{C}}$ \\
\hline \multicolumn{3}{|l|}{ Fixed Effects } \\
\hline \multirow[t]{2}{*}{ Intercept $^{\mathrm{a}}$} & $-.660 * *$ & $-.311 * *$ \\
\hline & $(.055)$ & $(.047)$ \\
\hline \multicolumn{3}{|l|}{ Community-Level Indicators } \\
\hline \multirow[t]{2}{*}{ Poverty Level } & .036 & $3.17 * *$ \\
\hline & $(.649)$ & $(.534)$ \\
\hline \multirow[t]{2}{*}{ Racial/Ethnic Heterogeneity } & .158 & $.489 *$ \\
\hline & $(.302)$ & $(.245)$ \\
\hline \multirow[t]{2}{*}{ Female-Headed Household } & $-1.828 *$ & -.035 \\
\hline & $(.055)$ & $(.638)$ \\
\hline \multicolumn{3}{|l|}{ Individual-Level Indicators } \\
\hline \multirow[t]{2}{*}{ Age } & -.002 & .005 \\
\hline & $(.006)$ & $(.006)$ \\
\hline \multirow[t]{2}{*}{ Black } & $-.430 *$ & $.323 *$ \\
\hline & $(.176)$ & (.161) \\
\hline \multirow[t]{2}{*}{ Hispanic/Latino } & -.165 & .066 \\
\hline & $(.172)$ & $(.162)$ \\
\hline \multirow[t]{2}{*}{ Native American } & -.289 & .206 \\
\hline & $(.459)$ & $(.436)$ \\
\hline \multirow[t]{2}{*}{ Violent Offense } & $.382 *$ & .125 \\
\hline & $(.162)$ & $(.154)$ \\
\hline \multirow[t]{2}{*}{ Ever Incarcerated } & .227 & .227 \\
\hline & $(.202)$ & $(.176)$ \\
\hline \multirow[t]{2}{*}{ H.S. Education } & .159 & -.111 \\
\hline & $(.119)$ & $(.106)$ \\
\hline \multirow[t]{2}{*}{ Unemployed } & -.162 & .148 \\
\hline & $(.108)$ & $(.097)$ \\
\hline \multirow[t]{2}{*}{ Married } & .237 & -.230 \\
\hline & $(.133)$ & $(.122)$ \\
\hline \multicolumn{3}{|l|}{ Variance Component } \\
\hline Intercept & $.613 * *$ & .154 \\
\hline \multicolumn{3}{|c|}{${ }^{\mathrm{a}}$ White arrestees represent the reference category. } \\
\hline \multicolumn{3}{|c|}{${ }^{\mathrm{b}}$ Chi-square $=1,229.729 ; \mathrm{df}=936$} \\
\hline \multicolumn{3}{|l|}{${ }^{\mathrm{c}}$ Chi-square $=982.050 ; \mathrm{df}=936$} \\
\hline${ }^{*} \mathrm{p}<.05 ; * * \mathrm{p}<.01 ;$ Standard errors & & \\
\hline
\end{tabular}




\section{E. Methamphetamines Models}

Table 1. HLM Regression Estimates of Cash and Noncash Transactions

\begin{tabular}{|c|c|c|}
\hline & $\operatorname{Cash}^{\mathrm{b}}$ & Nocash $^{c}$ \\
\hline \multicolumn{3}{|l|}{ Fixed Effects } \\
\hline Intercept $^{\mathrm{a}}$ & $\begin{array}{l}.523 * * \\
(.023)\end{array}$ & $\begin{array}{c}1.152 * * \\
(.030)\end{array}$ \\
\hline \multicolumn{3}{|l|}{ Community-Level Indicators } \\
\hline Poverty Level & & $\begin{array}{l}.127 \\
(.394)\end{array}$ \\
\hline Racial/Ethnic Heterogeneity & & $\begin{array}{l}.201 \\
(.175)\end{array}$ \\
\hline Female-Headed Household & & $\begin{array}{c}.032 \\
(.721)\end{array}$ \\
\hline \multicolumn{3}{|l|}{ Individual-Level Indicators } \\
\hline Age & $\begin{array}{l}.027 * * \\
(.003)\end{array}$ & $\begin{array}{c}-.028 * * \\
(.003)\end{array}$ \\
\hline Black & $\begin{array}{c}-.613^{* *} \\
(.105)\end{array}$ & $\begin{array}{l}-.101 \\
(.120)\end{array}$ \\
\hline Hispanic/Latino & $\begin{array}{c}-.361 * * \\
(.078)\end{array}$ & $\begin{array}{l}.005 \\
(.090)\end{array}$ \\
\hline Native American & $\begin{array}{l}-.249 \\
(.219)\end{array}$ & $\begin{array}{c}.083 \\
(.257)\end{array}$ \\
\hline Violent Offense & $\begin{array}{l}-.119 \\
(.062)\end{array}$ & $\begin{array}{l}.029 \\
(.071)\end{array}$ \\
\hline Ever Incarcerated & $\begin{array}{l}.159 \\
(.081)\end{array}$ & $\begin{array}{l}.159 \\
(.092)\end{array}$ \\
\hline H.S. Education & $\begin{array}{l}.162 * * \\
(.057)\end{array}$ & $\begin{array}{l}.113 \\
(.065)\end{array}$ \\
\hline Unemployed & $\begin{array}{l}-.043 \\
(.053)\end{array}$ & $\begin{array}{l}.349 * * \\
(.062)\end{array}$ \\
\hline Married & $\begin{array}{l}.159 * \\
(.066)\end{array}$ & $\begin{array}{l}-.141 * \\
(.072)\end{array}$ \\
\hline $\begin{array}{l}\text { Variance Component } \\
\text { Intercept }\end{array}$ & .008 & $.036 *$ \\
\hline
\end{tabular}

\footnotetext{
${ }^{\mathrm{a}}$ White arrestees represent the reference category.

${ }^{\mathrm{b}}$ Chi-square $=1,457.152 ; \mathrm{df}=1,334$

${ }^{\mathrm{c}}$ Chi-square $=1,335.166 ; \mathrm{df}=1,337$

${ }^{*} \mathrm{p}<.05 ;{ }^{*} \mathrm{p}<.01$; Standard errors in parenthesis.
} 
Table 2. HLM Regression Estimates of Noncash Acquisition Methods

Credit $^{\mathrm{b}} \quad$ Fronted $^{\mathrm{C}}$

Trade $^{\mathrm{d}} \quad$ Gift $^{\mathrm{e}}$

\section{Fixed Effects}

Intercept $^{\mathrm{a}}$

Community-Level Indicators

$\begin{array}{cccc}-2.384 * * & -2.580 * * & -2.130 * * & .880 * * \\ (.054) & (.058) & (.050) & (.032)\end{array}$

Poverty Level

Racial/Ethnic Heterogeneity

Female-Headed Household

Individual-Level Indicators

\begin{tabular}{|c|c|c|c|c|}
\hline Age & $\begin{array}{c}.009 \\
(.007)\end{array}$ & $\begin{array}{c}-.024^{* *} \\
(.008)\end{array}$ & $\begin{array}{l}-.009 \\
(.006)\end{array}$ & $\begin{array}{c}.008 \\
(.004)\end{array}$ \\
\hline \multirow[t]{2}{*}{ Black } & -.536 & .125 & -.319 & .230 \\
\hline & $(.274)$ & $(.237)$ & $(.229)$ & $(.151)$ \\
\hline \multirow[t]{2}{*}{ Hispanic/Latino } & .022 & -.262 & -.146 & .129 \\
\hline & $(.174)$ & (.196) & $(.161)$ & (.109) \\
\hline \multirow[t]{2}{*}{ Native American } & -.227 & -.421 & -.355 & .158 \\
\hline & (.553) & $(.611)$ & $(.490)$ & $(.322)$ \\
\hline \multirow[t]{2}{*}{ Violent Offense } & -.003 & -.240 & .003 & .097 \\
\hline & $(.142)$ & $(.160)$ & $(.128)$ & $(.088)$ \\
\hline \multirow[t]{2}{*}{ Ever Incarcerated } & .271 & .347 & .193 & -.289 \\
\hline & $(.205)$ & (.219) & $(.178)$ & $(.121)$ \\
\hline \multirow[t]{2}{*}{ H.S. Education } & -.009 & .122 & .158 & -.112 \\
\hline & $(.130)$ & $(.141)$ & $(.118)$ & $(.080)$ \\
\hline \multirow[t]{2}{*}{ Unemployed } & -.251 & .147 & $.567 * *$ & $-.213 * *$ \\
\hline & $(.121)$ & $(.126)$ & $(.105)$ & (.072) \\
\hline \multirow[t]{2}{*}{ Married } & .057 & $.330 *$ & .077 & $-.207^{*}$ \\
\hline & (.149) & (.157) & (.138) & $(.093)$ \\
\hline \multicolumn{5}{|l|}{ riance Component } \\
\hline ercept & .121 & .072 & .146 & .012 \\
\hline
\end{tabular}

\footnotetext{
${ }^{\mathrm{a}}$ White arrestees represent the reference category.

${ }^{\mathrm{b}}$ Chi-square $=939.271 ; \mathrm{df}=1,048$

${ }^{\mathrm{c}}$ Chi-square $=893.765 ; \mathrm{df}=1,048$

${ }^{\mathrm{d}}$ Chi-square $=912.839 ; \mathrm{df}=1,048$

${ }^{\mathrm{e}}$ Chi-square $=1,021.305 ; \mathrm{df}=1,048$

${ }^{*} \mathrm{p}<.05 ;{ }^{* *} \mathrm{p}<.01$; Standard errors in parenthesis.
} 
Table 3. HLM Regression Estimates of Cash Transactions and Method of Contact

Fixed Effects

Intercept $^{\mathrm{a}}$ Apt/house $^{\mathrm{b}} \quad$ Public $^{\mathrm{c}} \quad$ Person $^{\mathrm{d}}$

Community-Level Indicators

$\begin{array}{clc}-1.186 * * & -2.109 * * & -2.226 * * \\ (.039) & (.055) & (.052)\end{array}$

Poverty Level

Racial/Ethnic Heterogeneity

Female-Headed Household

Individual-Level Indicators

\begin{tabular}{|c|c|c|c|}
\hline Age & $\begin{array}{c}.009 \\
(.005)\end{array}$ & $\begin{array}{c}.010 \\
(.007)\end{array}$ & $\begin{array}{c}.001 \\
(.007)\end{array}$ \\
\hline Black & $\begin{array}{l}.115 \\
(.192)\end{array}$ & $\begin{array}{l}.606^{*} \\
(.233)\end{array}$ & $\begin{array}{c}.087 \\
(.273)\end{array}$ \\
\hline Hispanic/Latino & $\begin{array}{c}.140 \\
(.133)\end{array}$ & $\begin{array}{l}.449 * * \\
(.171)\end{array}$ & $\begin{array}{c}.130 \\
(.186)\end{array}$ \\
\hline Native American & $\begin{array}{l}-.315 \\
(.391)\end{array}$ & $\begin{array}{l}-.014 \\
(.512)\end{array}$ & $\begin{array}{c}-1.454^{*} \\
(.715)\end{array}$ \\
\hline Violent Offense & $\begin{array}{c}.007 \\
(.104)\end{array}$ & $\begin{array}{l}-.212 \\
(.144)\end{array}$ & $\begin{array}{c}.164 \\
(.143)\end{array}$ \\
\hline Ever Incarcerated & $\begin{array}{l}.443^{* *} \\
(.152)\end{array}$ & $\begin{array}{l}-.409 * \\
(.175)\end{array}$ & $\begin{array}{l}-.339 \\
(.186)\end{array}$ \\
\hline H.S. Education & $\begin{array}{l}-.072 \\
(.095)\end{array}$ & $\begin{array}{l}-.149 \\
(.126)\end{array}$ & $\begin{array}{c}.050 \\
(.136)\end{array}$ \\
\hline Unemployed & $\begin{array}{l}-.058 \\
(.087)\end{array}$ & $\begin{array}{l}-.195 \\
(.119)\end{array}$ & $\begin{array}{l}-.046 \\
(.124)\end{array}$ \\
\hline Married & $\begin{array}{l}-.141 \\
(.105)\end{array}$ & $\begin{array}{c}.036 \\
(.139)\end{array}$ & $\begin{array}{l}-.236 \\
(.153)\end{array}$ \\
\hline cept & .094 & .282 & .004 \\
\hline
\end{tabular}

\footnotetext{
${ }^{\mathrm{a}}$ White arrestees represent the reference category.

${ }^{\mathrm{b}}$ Chi-square $=1,066.948 ; \mathrm{df}=1,017$

${ }^{\mathrm{c}}$ Chi-square $=1,065.147 ; \mathrm{df}=1,017$

${ }^{\mathrm{d}}$ Chi-square $=1,016.118 ; \mathrm{df}=1,017$

${ }^{*} \mathrm{p}<.05 ;{ }^{*} \mathrm{p}<.01$; Standard errors in parenthesis.
} 
Table 4. HLM Regression Estimates of Noncash Transactions and Method of Contact Apt/house ${ }^{b} \quad$ Public $^{c} \quad$ Person $^{d}$

\begin{tabular}{|c|c|c|c|}
\hline \multicolumn{4}{|l|}{ Fixed Effects } \\
\hline Intercept $^{\mathrm{a}}$ & $\begin{array}{c}-1.416 * * \\
(.043)\end{array}$ & $\begin{array}{c}-2.241 * * \\
(.055)\end{array}$ & $\begin{array}{c}-.416 * * \\
(.030)\end{array}$ \\
\hline \multicolumn{4}{|l|}{ Community-Level Indicators } \\
\hline Poverty Level & $\begin{array}{c}.941 \\
(.550)\end{array}$ & & \\
\hline Racial/Ethnic Heterogeneity & $\begin{array}{l}-.162 \\
(.258)\end{array}$ & & \\
\hline Female-Headed Household & $\begin{array}{c}.514 \\
(1.003)\end{array}$ & & \\
\hline \multicolumn{4}{|l|}{ Individual-Level Indicators } \\
\hline Age & $\begin{array}{l}-.001 \\
(.005)\end{array}$ & $\begin{array}{c}.003 \\
(.006)\end{array}$ & $\begin{array}{l}.010 * \\
(.004)\end{array}$ \\
\hline Black & $\begin{array}{l}-.464 * \\
(.183)\end{array}$ & $\begin{array}{l}.263 \\
(.213)\end{array}$ & $\begin{array}{l}.159 \\
(.136)\end{array}$ \\
\hline Hispanic/Latino & $\begin{array}{l}.008 \\
(.123)\end{array}$ & $\begin{array}{l}.314 * \\
(.157)\end{array}$ & $\begin{array}{l}.102 \\
(.101)\end{array}$ \\
\hline Native American & $\begin{array}{l}-.194 \\
(.371)\end{array}$ & $\begin{array}{l}.263 \\
(.468)\end{array}$ & $\begin{array}{l}.197 \\
(.294)\end{array}$ \\
\hline Violent Offense & $\begin{array}{c}.052 \\
(.099)\end{array}$ & $\begin{array}{l}-.104 \\
(.133)\end{array}$ & $\begin{array}{c}.047 \\
(.082)\end{array}$ \\
\hline Ever Incarcerated & $\begin{array}{l}.386 * * \\
(.144)\end{array}$ & $\begin{array}{l}-.017 \\
(.174)\end{array}$ & $\begin{array}{l}-.274^{*} \\
(.109)\end{array}$ \\
\hline H.S. Education & $\begin{array}{l}-.081 \\
(.091)\end{array}$ & $\begin{array}{l}-.258 * \\
(.118)\end{array}$ & $\begin{array}{l}.064 \\
(.075)\end{array}$ \\
\hline Unemployed & $\begin{array}{l}.211^{*} \\
(.083)\end{array}$ & $\begin{array}{l}-.097 \\
(.111)\end{array}$ & $\begin{array}{c}-.311 * * \\
(.068)\end{array}$ \\
\hline Married & $\begin{array}{l}-.031 \\
(.108)\end{array}$ & $\begin{array}{c}.074 \\
(.139)\end{array}$ & $\begin{array}{l}-.224^{*} \\
(.088)\end{array}$ \\
\hline \multicolumn{4}{|l|}{ Variance Component } \\
\hline Intercept & $.159 * *$ & .332 & .033 \\
\hline \multicolumn{4}{|c|}{$\begin{array}{l}{ }^{\mathrm{a}} \text { White arrestees represent the reference category. } \\
{ }^{\mathrm{b}} \text { Chi-square }=1,180.630 ; \mathrm{df}=1,045 \\
{ }^{\mathrm{c}} \text { Chi-square }=992.016 ; \mathrm{df}=1,048 \\
{ }^{\mathrm{d}} \text { Chi-square }=1,096.852 ; \mathrm{df}=1,048 \\
{ }^{*} \mathrm{p}<.05 ;{ }^{* *} \mathrm{p}<.01 ; \text { Standard errors in parenthesis. }\end{array}$} \\
\hline
\end{tabular}


Table 5. HLM Regression Estimates of Cash Transactions: Purchase Directly and Source

\section{Fixed Effects}

Intercept $^{\mathrm{a}}$

Community-Level Indicators

Poverty Level

Racial/Ethnic Heterogeneity

Female-Headed Household

Individual-Level Indicators

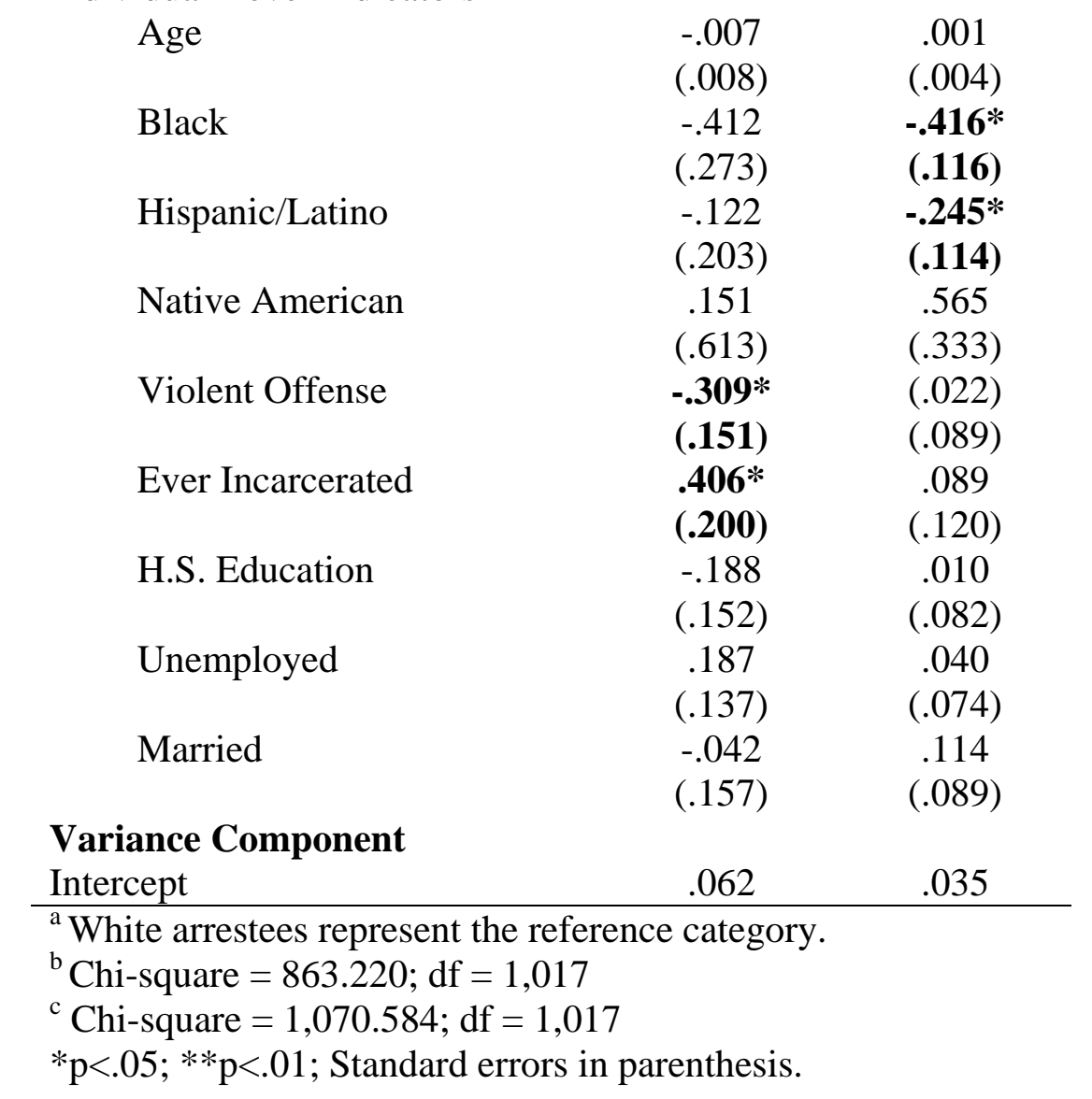

\section{Direct $^{\mathrm{b}} \quad$ Regular $^{\mathrm{C}}$}

$\begin{array}{cc}2.443 * * & .268 * * \\ (.058) & (.032)\end{array}$


Table 6. HLM Regression Estimates of Cash Transaction Location Purchase

\begin{tabular}{|c|c|c|}
\hline & House $^{b}$ & $\operatorname{Hood}^{\mathrm{C}}$ \\
\hline \multicolumn{3}{|l|}{ Fixed Effects } \\
\hline \multirow[t]{2}{*}{ Intercept $^{\mathrm{a}}$} & $.991 * *$ & $-.049 * *$ \\
\hline & $(.042)$ & $(.038)$ \\
\hline \multicolumn{3}{|l|}{ Community-Level Indicators } \\
\hline \multirow[t]{2}{*}{ Poverty Level } & -.778 & $1.377 * *$ \\
\hline & $(.542)$ & $(.500)$ \\
\hline \multirow[t]{2}{*}{ Racial/Ethnic Heterogeneity } & $-1.067 * *$ & $.529 *$ \\
\hline & $(.250)$ & $(.224)$ \\
\hline \multirow{2}{*}{ Female-Headed Household } & .723 & .654 \\
\hline & $(1.018)$ & $(.926)$ \\
\hline \multicolumn{3}{|l|}{ Individual-Level Indicators } \\
\hline \multirow[t]{2}{*}{ Age } & .004 & $.014 * *$ \\
\hline & $(.005)$ & $(.004)$ \\
\hline \multirow[t]{2}{*}{ Black } & $-.392 *$ & -.304 \\
\hline & $(.176)$ & $(.172)$ \\
\hline \multirow[t]{2}{*}{ Hispanic/Latino } & $-.257^{*}$ & -.048 \\
\hline & $(.121)$ & $(.116)$ \\
\hline \multirow[t]{2}{*}{ Native American } & -.378 & .098 \\
\hline & $(.340)$ & $(.322)$ \\
\hline \multirow[t]{2}{*}{ Violent Offense } & .029 & .085 \\
\hline & $(.098)$ & $(.090)$ \\
\hline \multirow[t]{2}{*}{ Ever Incarcerated } & .411 & $.412 * *$ \\
\hline & $(.128)$ & $(.128)$ \\
\hline \multirow[t]{2}{*}{ H.S. Education } & .112 & -.147 \\
\hline & $(.089)$ & $(.083)$ \\
\hline \multirow[t]{2}{*}{ Unemployed } & .102 & .079 \\
\hline & $(.082)$ & $(.076)$ \\
\hline \multirow{2}{*}{ Married } & .030 & -.130 \\
\hline & (.099) & $(.091)$ \\
\hline \multicolumn{3}{|l|}{ Variance Component } \\
\hline Intercept & $.170 * *$ & $.120 * *$ \\
\hline
\end{tabular}

\footnotetext{
${ }^{\mathrm{a}}$ White arrestees represent the reference category.

${ }^{\mathrm{b}}$ Chi-square $=1,164.025 ; \mathrm{df}=1,014$

${ }^{\mathrm{c}}$ Chi-square $=1,129.529 ; \mathrm{df}=1,014$

${ }^{*} \mathrm{p}<.05 ;{ }^{* *} \mathrm{p}<.01$; Standard errors in parenthesis.
} 